BIRDS' NESTS.

EGGS, AND

EGG-COLLECTING

R. KEARTON

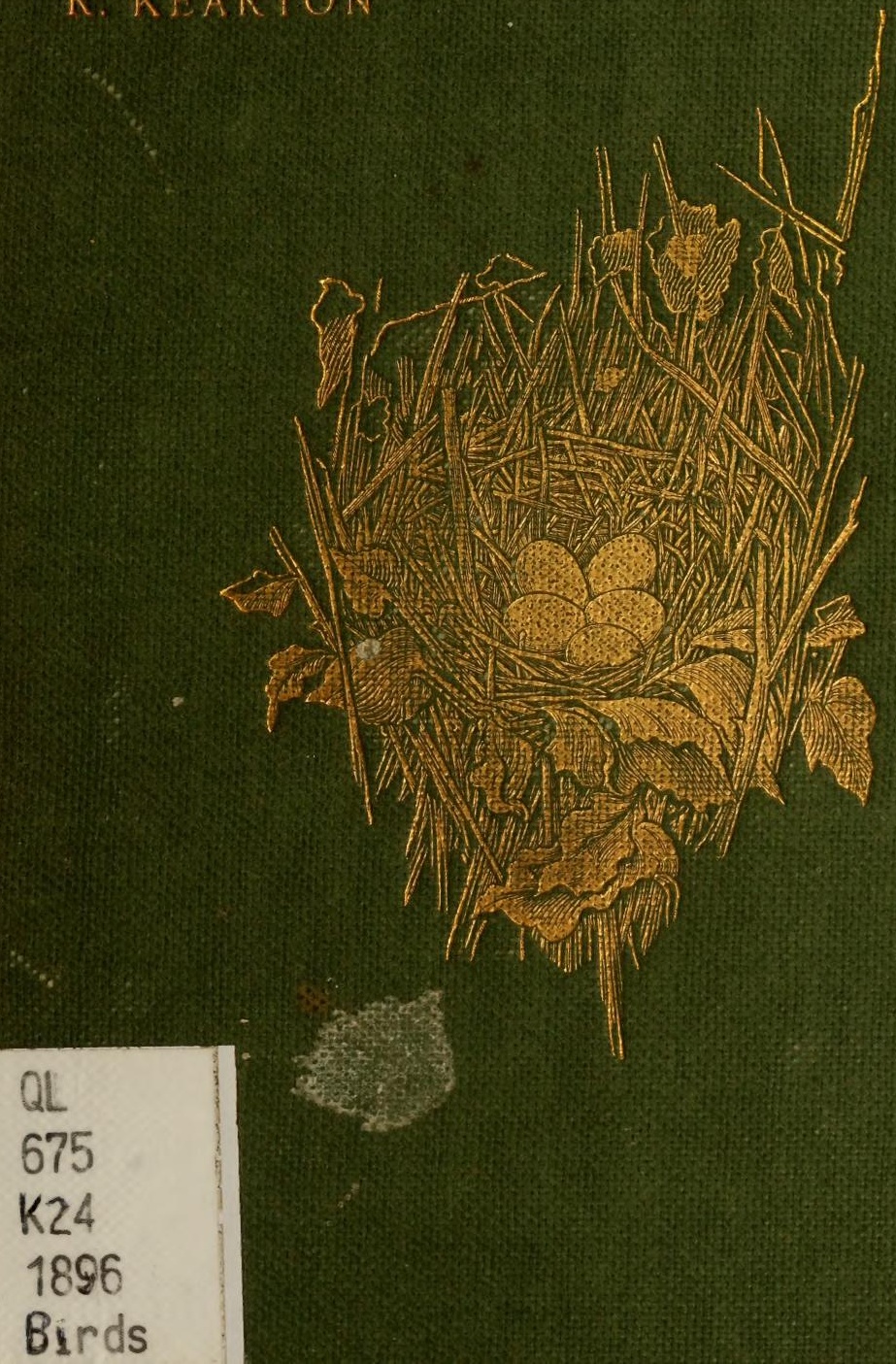




\section{Smithsonian Institution}

$\checkmark$ Sibraries

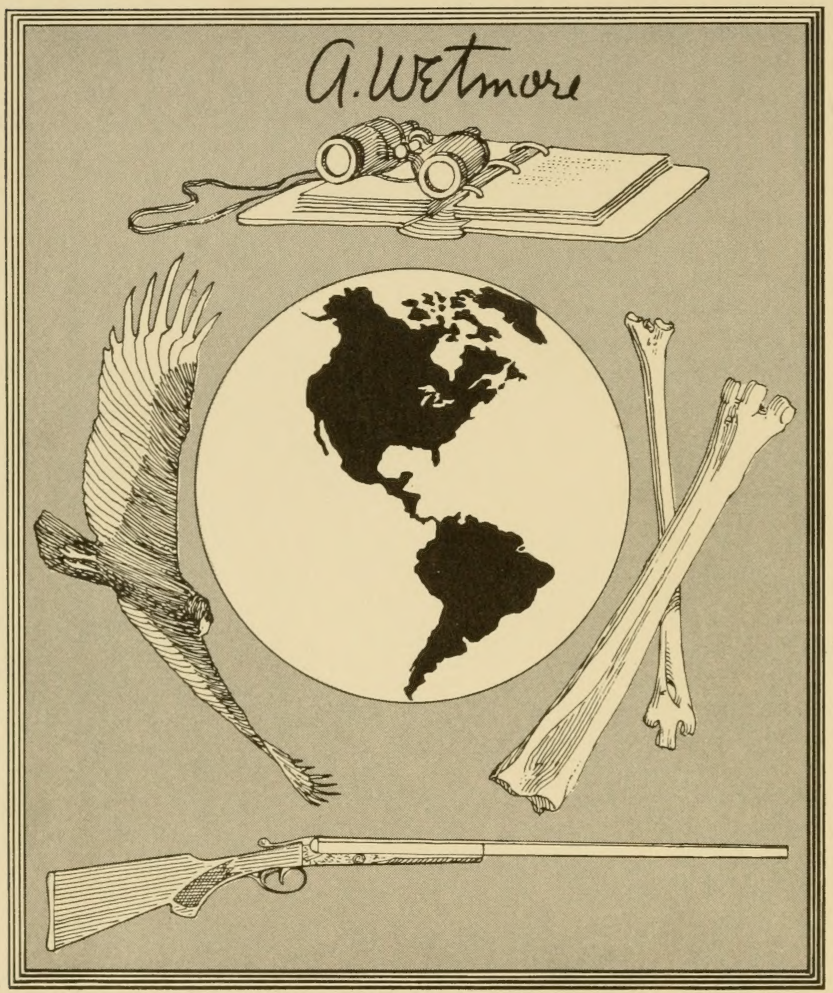

Alexander Wetmore 1946 Sixth Secretary 1953

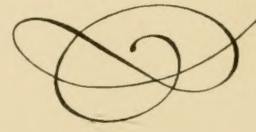


H. B. Cott.

E. 4

afuil.rigr.

A. Wrtmou Angust, 1967 




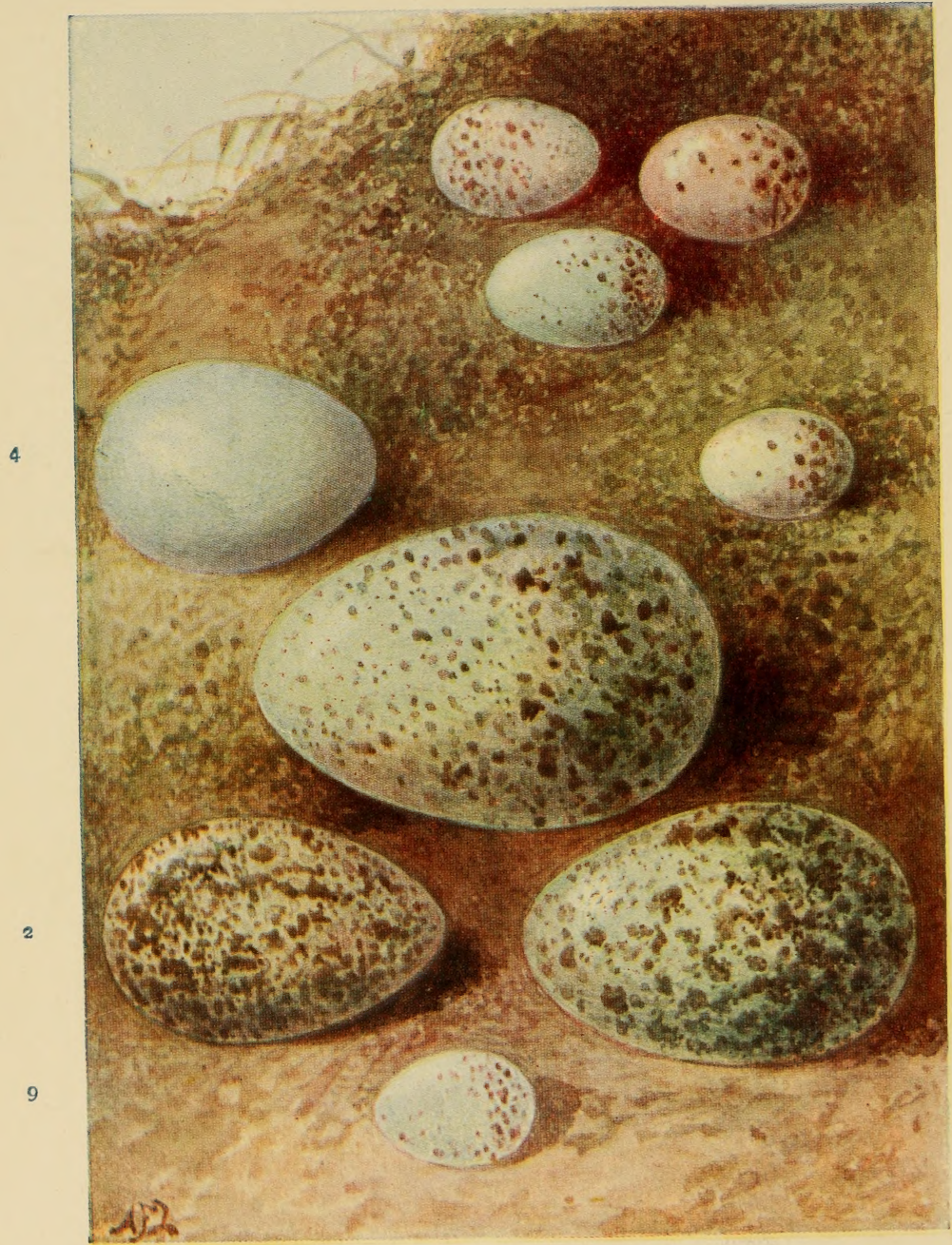

\section{EGGS.}

1. Goldfinch. 2. Magpie. 3. Bullfinch. 4. Starling. 5. Chaffinch. 6. Raven, 7. Linnet. 8. Rook. 9. Wren. 


\title{
'BIRDS' NESTS, EGGS AND
}

\section{EGG-COILECTING}

\author{
BY \\ R. KEARTON, F.Z.S.
}

AUTHOR OF “" With NATURE AND A CAMERA," “ BRitish BIRDs' NESTs," " WILD LIFE AT HOME," ETC.

\section{ILLUSTRATED WITH 2R COLOURED PLATES}

CA S SEL and COMPANY, Limited LONDON, PARIS, NEW YORK \& MELBOURNE. MCMV 


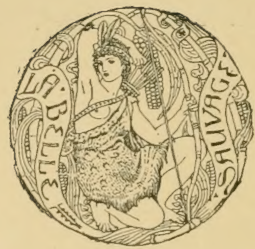

First printed February 18 go.

Reprinted June $1890, \times 893$.

New and Enlarsed Enition January 5 ; 96 .

Reprinted Fune 1896, 1898, 1900, 1902, 1903, Işc5. 


\section{PREFACE.}

THE very kindly reception by the press, and a steady public appreciation, have led to this endeavour to make my little book more complete, by preparing an Enlarged Edition, including all British-breeding birds that have now any reasonable claim for treatment. The work deals with a number of more or less familiar winter visitors that do not stay to breed with us; however, this is perhaps an advantage nowadays, when we all travel much and far.

As mentioned in the preface to the first Edition, this book is not intended to encourage the useless collecting of birds' eggs from a mere bric-ì-brac motive, but to aid the youthful naturalist in the study of one of the most interesting phases of bird life. It is to be hoped that the Act of Parliament empowering County Councils to protect either the eggs of certain birds, or those of all birds breeding within a given area, will be of great benefit to many of our feathered friends.

Besides a pretty extensive experience, I have, in the preparation of this work, sought the aid of such excellent authorities as Yarrel (fourth Edition), Seebohm, Dixon, and others, to all of whom I gratefully acknowledge my indebtedness.

\section{R. KEARTON.}

Boreham Wood, Erstree, Herts, 1896. 


\section{BY THE SAME AUTHOR.}

Wild Nature's Ways. With Rembrandt Frontispiece and 200 Illustrations from Photographs by C. and R. Kearton. 10s. $6 \mathrm{~d}$.

The Adventures of Cock Robin and His Mate. With upwards of 120 lllustrations taken direct from Nature by C. and R. KEARTON. 6s.

With Nature and a Camera. Illustrated by a Special Frontispiece and 180 Pictures from Photographs taken direct from Nature by CHERRY Kearton. Cheap Edition,7s.6d.

Our Bird Friends. With 100 Illustrations from Photographs by Cherry Kearton. 5s.

Strange Adventures in Dicky-Bird Land. Stories told by Mother Birds to Amuse their Chicks, and overheard by R. Kearton, F.Z.S. Illustrated from Photographs taken direct from Nature by C. Kearton. Price, eloth, 3ะ.6d.; cloth gilt, gilt edges, $5 \mathrm{~s}$.

Our Rarer British Breeding Birds: Their Nests, Eggs, and Summer Haunts. With about 70 Illustrations from Photographs by C. KEARTCN. Cireap Edition, 3s. 6d, net.

Wild Life at Home: How to Study and Photograph It. With Illustrations from Photographs taken direct from Nature by CHERRY KEARTON. 6s.

British Birds' Nests: How, Where, and When to Find and Identify Them. With Illustrations from Photographs of Nests, Eggs, Young, etc., taken in their Natural Situations and Surroundings, by C. KеAвтоs. 21s.

White's Natural History of Selborne. With Notes by R. KEARTON, F.Z.S., Author of "With Nature and a Camera," "British Birds' Nests," ete. Containing upwards of 120 Illustrations from Photographs by CHERRY and Richard KEARTON. $6 s$.

CASSELL \& COMPANY, Lmimted, London; Paris, New York \& Melbourne. 


\section{BIRDS' NESTS, EGGS, AND EGG- COLLECTING.}

\section{INTRODUCTION.}

The Problem of Preservation.-As a rule the first subject to which the young naturalist turns his attention is the most interesting one within his reach, and that subject is undoubtedly found in bird-life; particularly that portion of it which concerns the nests, eggs, young, and various modes of nidification, for this is really the kernel of ornithology. Its details teach him the utility of systematic study and close observation, two important points in all matters of scientific research.

It is my intention in the following pages to furnish as full and interesting particulars on Oology, which may fairly be entitled to the dignity of a science, as can be found, or is likely to be required, in any popular treatise of its modest compass.

This particular branch of natural history has been until lately but indifferently studied-in fact, considered unworthy of higher attention than that which could be bestowed upon it by schoolboys. People have been content to know that the wonderful architecture and mechanism of a bird's nest was the outcome of a force vaguely known as instinct, without taking the trouble to discover its workings, extent, or limits. 
Instinct is an extremely difficult power to define, and whether it be described as "hereditary habit," or simply accepted as an unknown law of Nature blindly followed by its possessor, it cannot be denied that it is the outcome of conditions, and always amenable to them. If the word mystery were often substituted for instinct, it would not be at all out of place, for it means quite as much. It is more honest to acknowledge our ignorance than to fence it round by speculative theory or cover it by almost meaningless phrases. Survival of the fittest is undoubtedly Nature's great law. With this end in view she governs and regulates the actions of birds in exactly the same way as she controls the colour and character of their plumage, shape, size, tint, and number of their eggs, first movements of their young, and other peculiarities we do not understand.

If we grant that birds possess highly-developed imitative faculties and tenacious memories, with a discriminating power which enables them to adapt certain habits of life to surrounding conditions, even this fails to explain a great deal. Supposing it is the secret of their beautiful nest-building, the house sparrow adopting trees to nest in where the houses are built of brick and lack crevices, or the falcon deserting its usual high inaccessible crag and nesting on the ground; it cannot possibly account for a young duck taking the water directly it has left the shell, or the habit of young plovers, snipes, grouse, and other birds crouching flat when danger is overhead even as soon as they are hatched. A stronger point still is migration, for birds cannot return to their old haunts by a memory of landmarks, as pigeons do even in their longest flights, for they fly over immense bodies of water and triverse 
vast tracts of land by night, on wings the length and strength of which have been specially developed for such long flights. Some fly across great stretches of country, yet are never seen except at the points from which they start and finish their flight. Neither ean these journeys be performed always under the guidance of leaders, for all migratory birds do not travel in flocks.

I will endeavour to point out how Nature has solved the problem of preservation; and it is equally interesting whether by the self-governed action of the bird, or the blind following of an impulse known only as instinct. Because we are unable to find any protective colouration in the plumage of a bird, its eggs or nest, we must not conclude that such peculiarity is a mere accident or useless decoration, for it either serves some wise end unknown to us, or has done so in far past ages, and is perpetuated because its possession is not distinctly harmful, and may at some future date be again called into requisition against danger. The extinction of nearly all birds whose existence is reasonably well known has not been due to natural causes, but to man or the influence his civilisation has introduced. Nature never made such a mistake as the introduction of rabbits and sparrows into Australia. They are two potent forces turned loose into practically unrestricted space, without any of their natural limiting influences.

Protective Colouring of Birds.-The protective colour of the plumage of certain birds is the great source of their safety during incubation. For instance, birds which nidificate on the ground, such as Black and Red Grouse, Pheasants, Partridges, and Sandpipers, all subject to the depredations of winged and creeping enemies, are prescrved by the modification of their tints. The sime 
means of security attend their eggs and downy young, even the extreme simplicity of their nests aiding the escape of detection. Birds whose down has protected them during the early part of their history, become aware of the dangers which threaten a more conspicuous plumage, which is a marvellous thing, whether acquired by reasoning or instinct. This is proved by the action of birds of the same order. The Golden Plover, with plumage in harmony with the surroundings of her nest (her feathers being still further subdued in colour during the breeding season), sits much closer than the Green Plover, although a shyer bird, with eggs possessing the same protective qualities. The Green Plover knows her plumage is much more conspicuous than her eggs, and quietly slips away before danger approaches half so near as the golden plover will allow it.

I am surprised to find so great an authority as Darwin assert that "the species which represent each other in distinct countries will almost always have been exposed to different conditions, but we can hardly attribute to this action the modification of the plumage in the males alone, seeing that the females and the young, though similarly exposed, have not been affected."

Possibly such may be the case where no protective modification is necessary in the female or young; but what about the fact that female Red Grouse differ much in the colour of their plumage, according to the conditions under which they live, though the males are left totally unaffected? Instance the female Grouse, known as the "Moss-hen," always found on the highest and most exposed situations where there is little cover, consequently great need of harmonising colours: a strong point, I venture to assert, in favour of protective utility. 
Moulting has been rendered subject to the law of preservation in a remarkable degree, for where birds are open to periodical changes of surrounding conditions which materially affect their existence, they are provided with an extra moult. For example, the Ptarmigan's plumage is pure white for winter snow, and brown for summer heather.

The stoat's fur undergoes a similar change of colour; and more marvellous still, to pursue the preservation argument into the water world, take a common trout, and chase him up and down a shallow pool until he has become thoroughly scared, and it will be found that wherever he rests for a few seconds his colour will change in obedience to that of the bed of the stream directly beneath him; so much so that I have known one half of a trout very dark and the other half very light coloured, correspondingly with objects beneath and around him.

Again, the same high authority points out that "the feathers of young birds are in male and female similar to the female parent when she is of a dull colour, but like the male when he is dull and the female bright; also, when both parents are of a conspicuously bright colour the young take a dull colour of their own" - for example, Robins. He infers that these colours represent those of far distant progenitors; but as safety lies in these modified tints, and preservation being Nature's chief problem, it is more reasonable to supposo that Nature lends this means of protection whilst the bird is in its most helpless condition, for an evolution that tends to increase dangerously conspicuous colours would only seem to invite extinction.

In another place he says " it deserves especial attention that brilliant colours have been transferred much more 
rarely than other tints." Yes, simply because they are generally a source of danger to the possessor.

Three familiar instances of special modifications in the plumage of the female are to be found in the black grouse, pheasant, and blackbird, all nidificating in situations more or less fraught with danger. Remarkable again is the fact that where the female is more conspicuously marked than the male the latter takes upon himself the duties of incubation entirely, or renders a great deal of aid, which is strong proof that dull subdued colours have been adopted for the preservation of the young in their several stages of helplessness.

Protective Construction of Nests.-It is surprising again to find Darwin, in arguing that ferw British birds build covered nests to protect themsclves against the conspicuousness of their orwn colours, citing the Dipper as an instance of this. But what about the white breast of this bird, which marks it out at long distances against the dark rock or water? Again, her pure white eggs are manifestly a source of danger, more conspicuous even than the bird. It must not be supposed I overlook another important feature in the covered nest of this bird, which is, horvever, subservient to the bird's desire to hide her white plumage and eggs, which renders it equally preservative in character. The bird gencrally builds near a waterfall, often quite behind, undoubtedly for the safety this situation affords, and she is not only obliged to construct a covered nest, but one which must keep out the constant dripping of water percolating through fissures in the rock. The construction of this nest even cuts off the chance of a stray splash of water finding its way to the eggs or young during the parent bird's absence, by the peculiarly ingenious entrance she makes to her little home. 
Still further, where birds are conspicuous in colour they either build covered nests, or place them in such situations as afford safety, and are thus equivalent. For instance, the Woodpecker, Kingfisher, and Magpie, the two former having a double object in the selection of a situation, firstly their own eminently brilliant colours, and secondly theirpure white eggs. The latter building a covered nest, of such materials as thorns, seems to point to a strategic plamning against the immorality of the family to which he belongs.

Periods of Incubation and their Utility.-The Duck family all lay eggs white, or nearly approaching it, and take the precaution to cover them carefully on leaving the nest.

Some naturalists have been of opinion that this is to prevent an undue escape of the heat generated by the parent; however, I am unable to find any observations to prove that these birds leave their egrgs for feeding purposes longer than any others that hatch their young in three weeks. Neither does it appear that they transmit heat better or worse than birds of entirely different habits, for it takes a Forwl four weeks to hatch a Duck's egg, and a Duck will on the other hand hatch a Forwl's in the normal time, three weeks. It appears that the period of incubation is regulated with a great amount of precision by the contemplated habits of life, the difficulties to be overcome, and dingers to be endured, as the following facts show :-

A Pigeon hatches its young out in sixteen days, and by a special process and careful assiduity feeds them until they are almost full grown. A Fowl, though not capable of feeding her young in the same way, possesses the power of defending her offspring, finding and selecting suitable food, and attending to their education generally in a bigher 
degree than the Duck can bestow on her progeny, which take four weeks to hatch.

To still further illustrate this wonderful regulating principle, let us diverge for a moment from the eggs of birds to those of fish, where we find things adapted with incredible precision to the surrounding conditions of existence. I have noticed that trout living and being obliged to deposit their ova in a stream subject to great variations of temperature, spawn much earlier than trout in a stream preserving a comparatively even temperature. The condition of the latter in comparison with the former showed unmistakably that the difference of food supply did not account for it, and as the fry in both streams appeared about the same time in the spring, and exhibited no appreciable difference in size or strength during the summer, the natural conclusion to be arrived at is that the time required for hatching in each stream is contemplated and provided against in some mysterious way.

Mechanical Construction of Eggs.-We now come to another phase of the protective principle, even more remarkable than those we have already discussed, and equally useful. This is in the mechanical construction of eggs to suit their situation and surrounding conditions. What an admirable provision Nature has shown in placing the axis of a bird's egg just where it will prevent it rolling off a flat surface, such as a ledge of rock, when moved by the terrible gusts of wind that sweep over high latitudes, or perhaps roughly moved by the parent-bird suddenly fluttering off when scared.

Take, for example, the egg of the Guillemot. This is so wonderfully constructed that if moved it will not roll away like a marble or billiard-ball, but simply spins round on its axis, in the same way as a screw or top, showing 
a wonderful adaptability to the exposed situation chosen by this bird for incubation.

Birds which make round, cup-shaped nests. or incubate in holes, such as the Orwl and Kingfisher, for instance, lay round eggs, which run no risk of rolling away and being smashed. Their shape also facilitates alteration of position of the parent-bird to secure an equal distribution of warmth and ventilation.

Were the Guillemot and either of the latter birds to change nesting situations for a while, it is proballe a speedy extermination of the species which adopted the flat rock for the round egg would soon take place, affording a beautiful illustration of the porrer that is also guiding the action of birds under the mysterious name of instinct. It is an unknown and unknowable power, yet its workings are as undeniable as its results.

As a further illustration, let us take the egges of the Golden and Green Plovers, and consider for a moment their size, shape, number, and colour.

All these qualities serve some well-defined and demonstrably useful end. Firstly, their size is abnormally large compared with that of the layer, but this is a provision which supplies the necessary size and strength of the young bird to enable it to cope with the surrounding conditions of its first days of self-feeding and locomotion amongst coarse grass and other obstacles.

Secondly, the shape of the egg serves to economise space, an important point where the eggs are large and the bird small. Thus the four pear-shaped eggs, having their small ends all pointing to a common centre, practically form a square, and thus enable the bird to cover them all at the same time. 
Thirdly, the number of eggs is always four, and by such limitation the form of the square is preserved, and the difficulty of a small bird covering a number of large eggs satisfactorily surmounted. I have often disarranged the order of Plovers' eggs, but always found that the first thing done by the bird on her return was to reduce chaos to order by turning the round ends out and the small ones into the centre of her little household.

Lastly, we come to the beautiful harmony of colouring of the eggs with surrounding objects, rendering them often very difficult to find, even by a practised eye, and the scant nest still further aiding in the chances against discovery.

The Sandpiper affords an admirable instance of the assimilation of its eggs to surrounding objects, and the extreme difficulty experienced in finding them attests to its protective utility.

Why Eggs Vary so much in Point of Number.The number of eggs laid by birds of different orders seems to be regulated by the danger to which they are exposed and the amount of food which the parents will be able to supply.

Thus, the Eagle in its inaccessible eyrie enjoys almost perfect immunity from danger, and has only two young ones, for which, however, the supply of food is only equal to the demand, and it is probable that one more voracious appetite would seriously endanger the safety of the whole family.

On the other hand, take the Common Partridge with its sixteen or twenty eggs, the high percentage of its dangers, and the generally abundant supply of food.

Again, the Swift, on its untiring wings for sixteen 
hours a day, avoids the majority of dangers which threaten less favoured birds, and only lays two egge, in a position very few other birds could adopt, yet one which secures her little household the amount of safety necessary for the due survival of the species. However, with her limited family, dexterity on the wing, and enduring powers, she seems to have no leisure time during the period her young require feeding. As an opposite, take the House Sparrow, with its five or six eggs, innumerable dangers, and easy access to food, and it must be confessed these things are ordered by a power of infinite wisdom.

Curious Nesting-Places.-The general situation and locality in which each bird's nest is likely to be found are mentioned in dealing with the bird under its separate heading; however, it may not be uninteresting to chronicle a few of the most remarkable and well-authenticated departures from accepted rules.

I have myself found a Dipper's nest on the branch of a tree twelve or thirteen feet from the water and twenty from the bank. This nest was of ordinary shape and size, its material being of the same kind as others, and securely fastened amongst the prongs of the branch like a Missel Thrush's. When the parent bird was disturbed she dived into the pool below to make her eseape (a habit invariably adopted when nesting in an ordinary position). She reared her young in safety, however, in spite of the awkward situation she had selected, and I have every reason to believe got them off without mishap. I have also found a Thrush's nest on the ground, precisely in the position a Lark selects.

House Sparrows furnish many examples of curious situations adopted for incubatory purposes. Not long ago a pair of these birds built their nest, and success- 
fully hatched a brood, in the cartridge-box of a cannon which was fired twice daily in the Gun Park at Woolwich. It is a notable fact that in some parts of the country Sparrows build extensively in trees, whilst in others such a circumstance is unknown. Some ornithologists are of opinion that it is an hereditary habit, others supposing that it is resorted to for the sake of coolness in hot weather; but a reason I incline to is that in parts of the country where houses and out-buildings are made of stone the birds find ample accommodation in joints, crevices, and crannies where the mortar has been dislodged, and are therefore not driven to the necessity of adopting trees, like birds found in districts where the houses are made of bricks, consequently closer, and affording less opportunity for nest-building. This bird, besides its noted pugnacity, is an arrant rogue, and invariably takes advantage of the House Martin's labour. I have known a house with twenty nests all close together under its eaves, about half of which were occupied by Sparrows, which had, in some cases where the nests were new, been actually watched ejecting the eggs of the original owners.

The Robin is noted for its caprice in the selection of a nesting site, and has been found hatching its eggs in nearly every conceivable situation, from the ordinary mossy bank to the pocket of a gardener's old coat which had been hanging undisturbed for several weeks in a toolhouse. Old kettles, water-cans, inverted plant pots, \&c., in buildings close to machinery in daily motion, and other equally curious places, are by no means rare occurrences. A case is recorded of a Robin's nest having been built in the hole made by a cannon-ball through the mizzen-mast 
against which Lord Nelson was standing when he receiveri his death-wound on board the Victory.

Swallows have also been known to adopt quite foreign situations for breeding purposes, such as holes in trees, and even openly on the branches.

Cases are known of the Starling building its nest down holes in the earth, and also quite exposed in trees, similar to the nest of the Sparrow. It has also been found going shares with a Magpie.

The Pied Wagtail occasionally chonses strange (prarters, one case being on record of a pair building beneath a railway switch, over which trains passed nearly every hour in the day within a few inches of the nest.

The roof of a house in Hull was once selected by two pairs of Rooks for nidification, and proved a successful choice, for they managed to build nests and rear their young.

The Common Wild Duck is also liable to depart widely from her usual babit in the selection of a site for lier nest, sometimes adopting a Crow's nest, and even the tower of a church, which latter has occasioned much speculation amongst naturalists as to how the parent bird managed to convey her progeny safely to water.

The Flycatcher is amongst the foremost of our eccentric birds in the choice of breeding quarters, its nest having been found in street lamps in different parts of the country, and in one instance on the head of a hoe hanging against the wall of a tool-house. The nest was removed whilst the hoe was being used, and, when replaced, the birds, instead of deserting it, resumed operations, and eventually reared their brood.

Another very interesting curiosity of recent date 
occurred in the neighbourhood of Skegness, where a pair of Marsh Titmice selected a farmer's letter-box for incubation purposes, and although it was opened twice daily, and the materials with which the birds began to build were several times cleared away, they doggedly persisted in their efforts, and eventually succeeded in making a nest and depositing the usual number of eggs.

One of the strangest cases of all, and I should think the most remarkable on well authenticated record, recently occurred near Colchester, where a pair of Common Wrens built their nest inside the skeleton of a hooded crow, which had been brought to justice and hung up as a warning to other winged depredators.

These odd positions and situations are evidently not chosen for purposes of concealment from man, at any rate; indeed, it is a question whether some of them are not adopted to secure the advantage his presence affords against the incursions of predatory birds and animals. And, on the other hand, if these seeming departures from instinct be admitted as due to reason, it seems strange that whilst some birds are capable of this, others exhibit what seems to human understanding profound stupidity. I have linown birls vainly try to build in positions where it was impossible for a nest to rest, each piece of material falling to the ground, until sufficient had been collected for a great many nests; yet the bird kept on collecting sticks, moss, and grasses, until probably she was obliged to drop her eggs in the fields. This is not a solitary instance, nor only once attempted, for close observation proved that the same inexplicably vain effort was continued from year to year, but whether by the same birds or not it is of course impossible to say. 
Some birds show a remarkable love for the same situation, in which they nest year after year for an incredible length of time. The same place is known to have been used by falcons for about a century and a quarter, and likely to continue if the birds are not molested. Blue Titmice are known to have selected the same quarters over a hundred years in unbroken succession.

On Forming a Collection.-My concluding remarks will be devoted to the guidance of such as require to make a collection of eggs.

Keep close watch on the building operations of the birds whose eggs are required. Dippers, Thrushes, and many others commence early in the spring, especially after a mild winter.

Take only one specimen, and not until you have reason to believe the bird has done laying. Never under any circumstances take an egg when you have ground to suppose incubation has commenced, or is in an advanced stage, for besides the cruelty of the thing, it will often be of no use.

The specimen being secured, it is taken for granted the collector is furnished with the necessary drill and blowpipe, procurable at any naturalist's shop. The next proceeding is to drill a small hole exactly on the side of the egg, selecting that of a spotted one with the least characteristic marks on it. Then insert the end of the blow-pipe, or rather direct the current of air sent through it into the hole made, being careful with small eggs not to burst them, or squeeze them until they collapse under the pressure of the fingers. When the contents have been emptied wash the egg out with clean water, introduced through the blow-pipe, being careful not to wet the outside more than necessary, or rub it too 
much, as the beautiful colouring of many eggs is easily displaced. When the egg has been blown, and properly dried inside and out, an operation needing some care, the hole should be covered over with a neat piece of gummed paper, on which the name of the specimen may be written, this being found especially useful when eggs of different kinds get mixed.

A small label should also be attached to the compartment allotted to each egg in the cabinet, bearing the name, locality in which it was found, and date, as such memoranda are often very useful, and inculeate habits of systematic study and storage of information sometimes impossible to remember. Besides this, a very good plan is to keep a note-book in which to enter such particulars and data concerning each specimen as may prove of utility or interest in the study of oology.

Of course it is impossible to obtain many specimens, which are seldom or never found in certain districts, therefore it is necessary to buy such eggs, or exchange through the medium of advertisement, with collectors equally glad to avail themselves of such an arrangement.

I have no doubt about the pleasure a study of the subject affords, and if my little book assists to heighten it in any way I shall be satisfied.

R. KEARTON. 


\section{BIRDS' NESTS AND EGGS.}

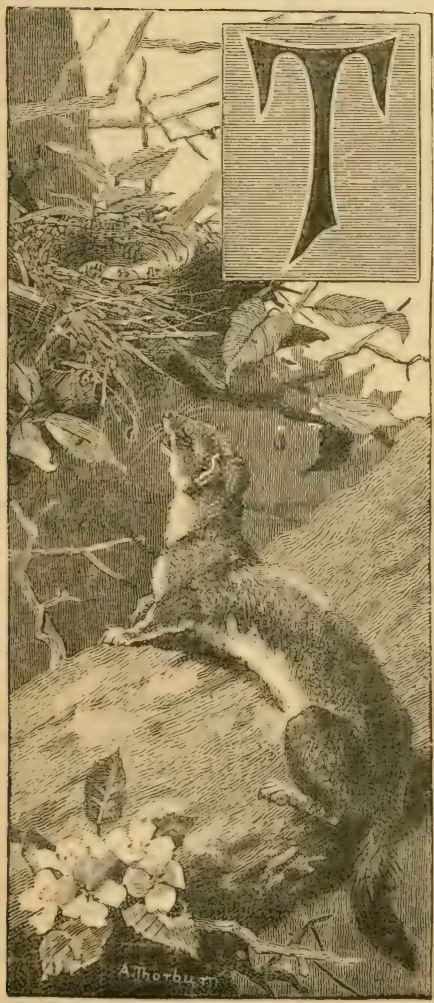

\section{THE GOLDFINCH.}

HIS beautiful little biru builds a nest of the first rank in point of constructive skill and neatness. Though it breeds at a surprisingly rapid rate, it is a regrettable fact to learn tkat its numbers are gradually becoming smaller in this country, and mainly through the profit its capture affords. Despite being much harassed by the birdcatching fraternity to supply the demand for it as a cage pet, if not actually approving of confinement, it seems to prefer the close proximity of man, often selecting as a nesting situation gardens and orchards, and has even been known to build in rose-bushes and other trees trained against 
a dwelling-house. The nest is composed of moss, a little hay and wool, lined with seed-down of the willow and hair neatly woven together. The eggs are four or five in number'; white, tinged with blue, and spotted at the larger end with raw sienna.

\section{$\checkmark$ THE MAGPIE.}

Trie Magpie builds her nest on the tops of very tall trees, but it has sometimes been found in comparatively small bushes. It is large, domed, and almost spherical in shape, composed of brambles, thorny sticks, clay, and finer sticks, and lined inside with dead grass and fibrous roots; it has a hole on the side. She lays six or seven eggrs of a dirty light blue, spotted with yellowish-brown all over.

\section{$\checkmark$ THE BULLFINCH.}

Tris bird lays four or five eggs of a pale blue colour, spotted and streaked with raw sienna, brown, or purple. The nest is made of twigs and fibrous roots, and lined with horsehair ; it is situated in thick garden and other hedges. The female sits very close, so that she may even be touched without leaving the nest.

\section{$\checkmark$ iThe STARLING.}

Tire Starling makes her nest of hay, straw, and fibrous roots; her favourite haunts are the gable-ends of old houses, cliffs, and hollow trees. She lays four or five eggs of a beautiful light blue, tinged with green. If she is left undisturbed, she will use the same nest for several years, with a little repairing each spring. She is very affectionate to 
her young, and works in hearty co-operation with her mate to procure them food, which is an enormous quantity in the course of a day.

\section{$\checkmark$ THE CHAFFINCH.}

The Chaffinch generally builds her nest in the forks of trees covered with lichens; it is made of moss, wool, and lichen, the inside being lined with hair and feathers. She makes a beautiful nest, small but deep, and it harmonizes so much with its situation that it is often difficult to fund. She lays four or five eggrs of a grayish-blue, spotted and streaked with a dirty purple-red. She sits very close, in fact I once knew a bird remain on her nest till a mischicvous boy caught her by the tail, pulling it out as she rose to fly; and she returned and reared her young after that.

\section{THE RAVEN.}

TiIe Raven lays five or six eggs of a gray-green ground colour, spotted and blotched with a darker greenish or smoky brown. She builds her nest in high, inaccessible rocks and cliffs, either on the sea-shore or inland, and it is sometimes found on the tops of lofty trees. It is composed of sticks of various sizes and kinds, wool, and hair.

\section{$\sqrt{\text { THE LINNET. }}$}

THis little bird lays from four to six eggrs of a whitish faint blue tinge, speckled with purple-rerl, and her nest is composed of moss, bent fibrous roots, and wool, lined inside with hair and feathers. She builds in whitethorn, blackthorn, and furze bushes; very rarely in trees. 


\section{$\sqrt{\text { THE ROOK. }}$}

The Rook lays four or five eggs of a pale green colour, spotted and blotched with greenish or smoky brown. She makes her nest of sticks, straw, hay, \&c., and is rather particular about it, pulling it to pieces and rebuilding it several times. Tall trees are usually selected, generally near to some mansion or village, where the roots form a colony. This bird lays very early, and has been kuown to commence sitting even in November.

\section{THE COMIION IVREN.}

Turs little bird lays four to eight eggrs of a yellowishwhite tinge, spotted at the larger end with a lind of brownish-red. It builds several supplementary nests, which are simply made of moss and lichen; this is attributed to the male bird by some naturalists; but however this may be, as a rule two of these nests will be found to one of the othnrs lined with feathers, which is intended for incubation. The nest is built in old barns, on the sicles of cliffs, and in the roots of trees growing from high banks; it is dome-shaped, and has a very small entrance.

\section{$\sqrt{\text { THE JAY. }} \quad x$}

TuE Jay lays five or six egrgs of a pale greenish-blue, sometimes yellowish-white, thickly spotted with minute brown spots, generally confluent on the larger end, where there are several irregular black lines. She builds her nest in the thickest parts of woods, where it may be weli out of sight. It is composed of sticls, small twigs, small fibrous roots, and grass. 



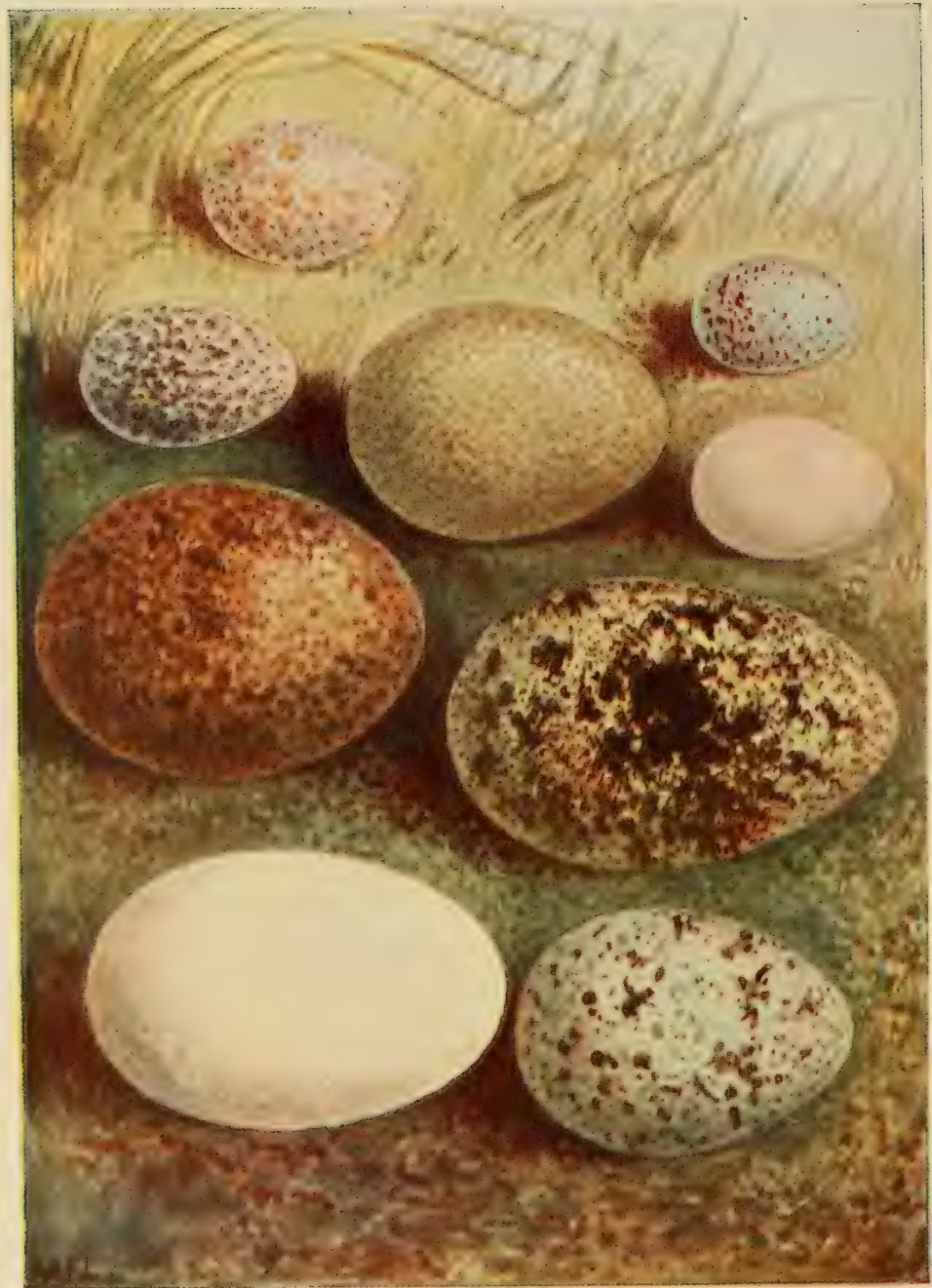

\section{EGGS.}

1. Jay. 2. Sparrow. 3. Jackdaw. 4. Grouse. 5. Kestrel. 6. Robin 7. Redpoll. 8. Ringdove. 9. Wryneck. 


\section{$\checkmark$ THE HOUSE SPARROW.}

"'irrs familiar little bird builds her nest in the walls of old stone houses, at the back of spouting, and amongst ivy. It is particularly fond of ejecting the Martin from her carefully-built home, and has been even known to turu out the eggrs of this little harmless bird. She lays five or six egrs, of a dirty white, covered with black or dark brown spots.

\section{$\checkmark$ THE JACKDAW.}

THe Jacklaw builds her nest in torvers of churches, the ruins of old castles and abbeys, rocks, hollow trees, and chalk pits. It is made of sticks, strarv, and hay, with an inner lining of large feathers, hair, and wool. The egge, numbering from three to six, are a pale green-blue, spotted with dingy brown; the spots are confluent at the larger or thicker end.

\section{THE COMIION GROUSE.}

True Grouse lays on an average about nine eggs; as many as fifteen have been found, but this number has been by some attributed to two birds, as they will sometimes build (if we may term it such) within a yard of each other. Their nests merely consist of a little hollow scratched out, and lined with heather or bent. The eggs are of a dirty white colour, covered with umber-brown spots. Both the old birds are very cunning in trying to decoy the intruder away from the whereabouts of the nest, feigning lameness or injury.

\section{THE KESTREL.}

The Kestrel lays four to seven egges of a dirty white, sometimes with a bluish tinge, thickly covered with reddish- 
brown blotches. She generally makes no nest at all, but scratches a hollow in the soft earth on a ledge of rock situated on high mountain or sea cliffs. The deserted nest of the crow is sometimes utilised.

\section{$\sqrt{\text { THE ROBIN. }}$}

Tris beautiful little bird, the favourite of English children, builds her nest in walls and banks, where roots and moss abound. It is composed of moss, fibrous roots, and leaves, and is sometimes lined with hair. She lays five or six eggs of a very light gray, spotted with a dull light red; sometimes these spots are very few.

\section{THE REDPOLL.}

T'rie eggs of this bird are four or five in number, of a very pale blue-green colour, spotted about the larger end with orange-red. The eggs retain much of their pretty colour after being blown, they are of such a beautiful blue. She makes her nest of hay and moss, lined inside with willowdown, and finishes it off in the most beautiful manner. She builds her nest in willows, alders, and other bushes that fringe streams and ponds in mountainous districts.

\section{$\int$ THE RINGDOVE.}

THe Ringdove makes a very loose, slovenly nest of twigs and sticks, and it is sometimes so badly built that the eggs may be seen through the bottom of the nest. She builds in fir, yerv, or other trees, sometimes in ivy that grows upon rocks and trees, very near the ground. She lays two white eggs of a rounded oval shape. 



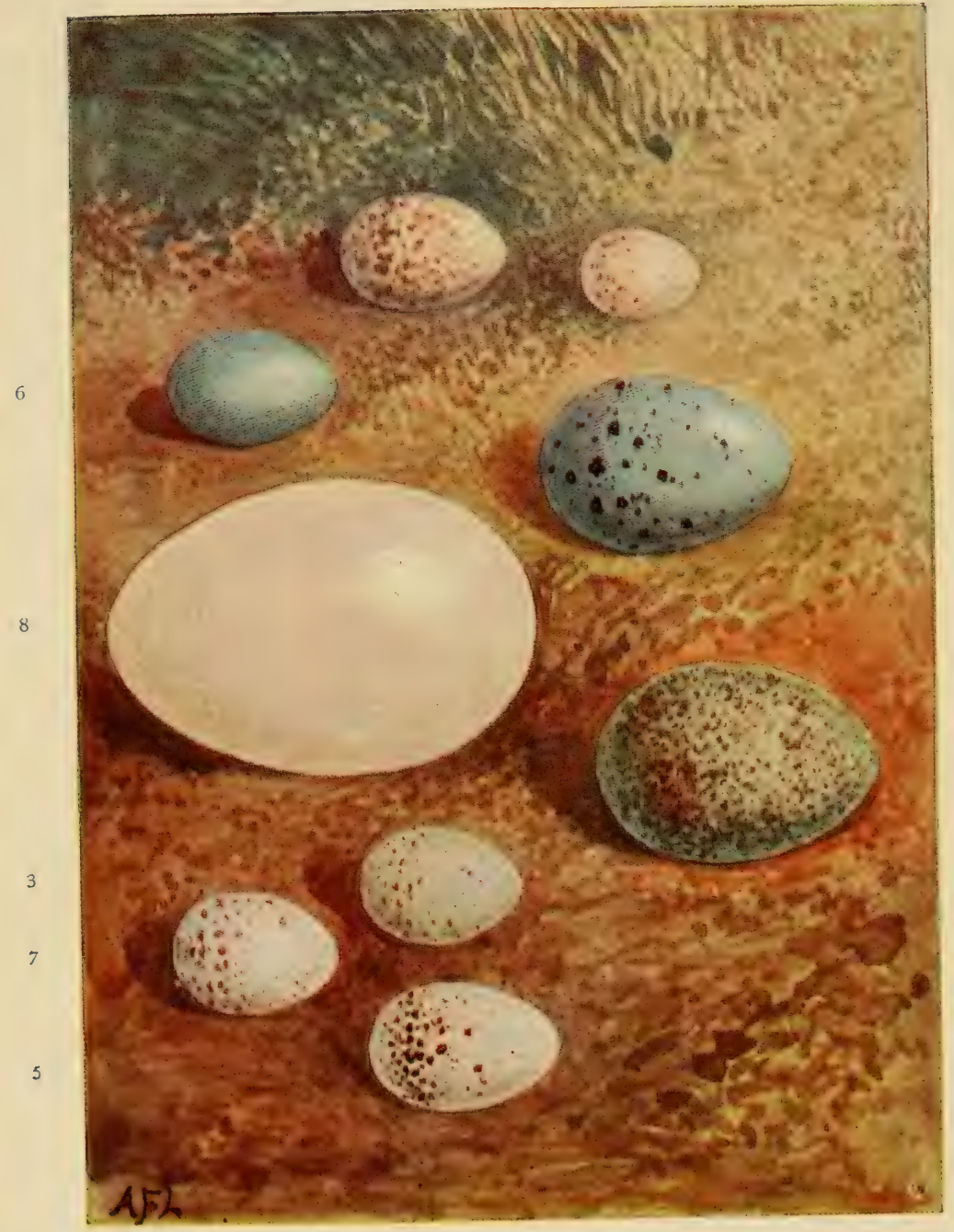

\section{EGGS.}

?. Golden-crested Wren. 2. Whitethroat. 3. Siskin. 4. Thrush. 5. Greenfinct. 6. Redstart. 7. Great Tit. 8. Teal. 9. Blackbirù. 
THE WRYNECK.

Trre eggs of this bird are from five to eight in number, of a pure white. She makes her nest in holes in the trunks of trees. It is made of dry, rotten wood, which is ground down to a kind of powder, and it has been found lined with moss and feathers.

\section{THE GOLDEN-CRESTED WREN.}

Triss little bird, like the others of its tribe, lays a considerable number of eggrs for its small size. They are eight or nine in number, thickly spotted with reddish-brown, these spots being confluent at the larger end. The underground colour is a faint fleshy tint. Her nest is made of moss and lichens, and is lined with willow-down and feathers. The outside of the nest generally harmonises with its situation, which is amongst the branches of a tree, generally of the fir, from a branch of which the nest is usually suspended.

\section{$\sqrt{ }$ THE WHITETHROAT.}

Tue Whitethroat lays four or five eggs of a greenishwhite colour, spotted with brown and gray, the spots sometimes form a zone or belt round the larger end. Her nest is made of dead grass and a little hair, loosely attached, the nest being carelessly made. It is situated in low thick herbage, or amongst nettles, or other ground weeds.

\section{THE SISIKIN.}

Tins bird lays four or five eggs of a bluish grround colour, some being spotted all over with cloudy rusty spots, cthers with these spots well defined about the larger end. Hor 
nest is made of green moss, small twigs, dried grass, and sometimes lined with feathers and rabbits'-down. The nest is rarely found in Britain; its usual situation is amongst furze-bushes.

\section{$\sqrt{\text { THE THRUSH. }}$}

TuE Thrush builds her nest in hedges, banks, against the trunks of trees, in stone walls, and is fond of ivy against trees or rocks. Her nest is made of grass and moss, the interior being lined with clay or cow-dung, in which are sometimes found pieces of decayed wood. She lays from four to six eggs, of a beautiful blue spotted with black, most of the spots being on the thick end of the egg.

\section{$\sqrt{ }$ THE GREENFINCH.}

This bird lays four or five eggs, which are white tinged with blue, and speckled at the larger end with light orangebrown. Her nest is situated in thick hedges, ivy, holly, and other evergreens. It is composed of moss and wool, and is lined with hair and feathers. The nests of these birds have been found so close that the material of two was interwoven together.

THE REDSTART.

Tire nest of this bird is made of moss lined with hair and feathers. It is situated in holes in rocks, walls, trees, stables, and barns; and the bird has been known to build in a plant pot with the bottom upwards, entering through the hole. She lays from five to seven eggs, of a pale bluish.green, unspotted. 



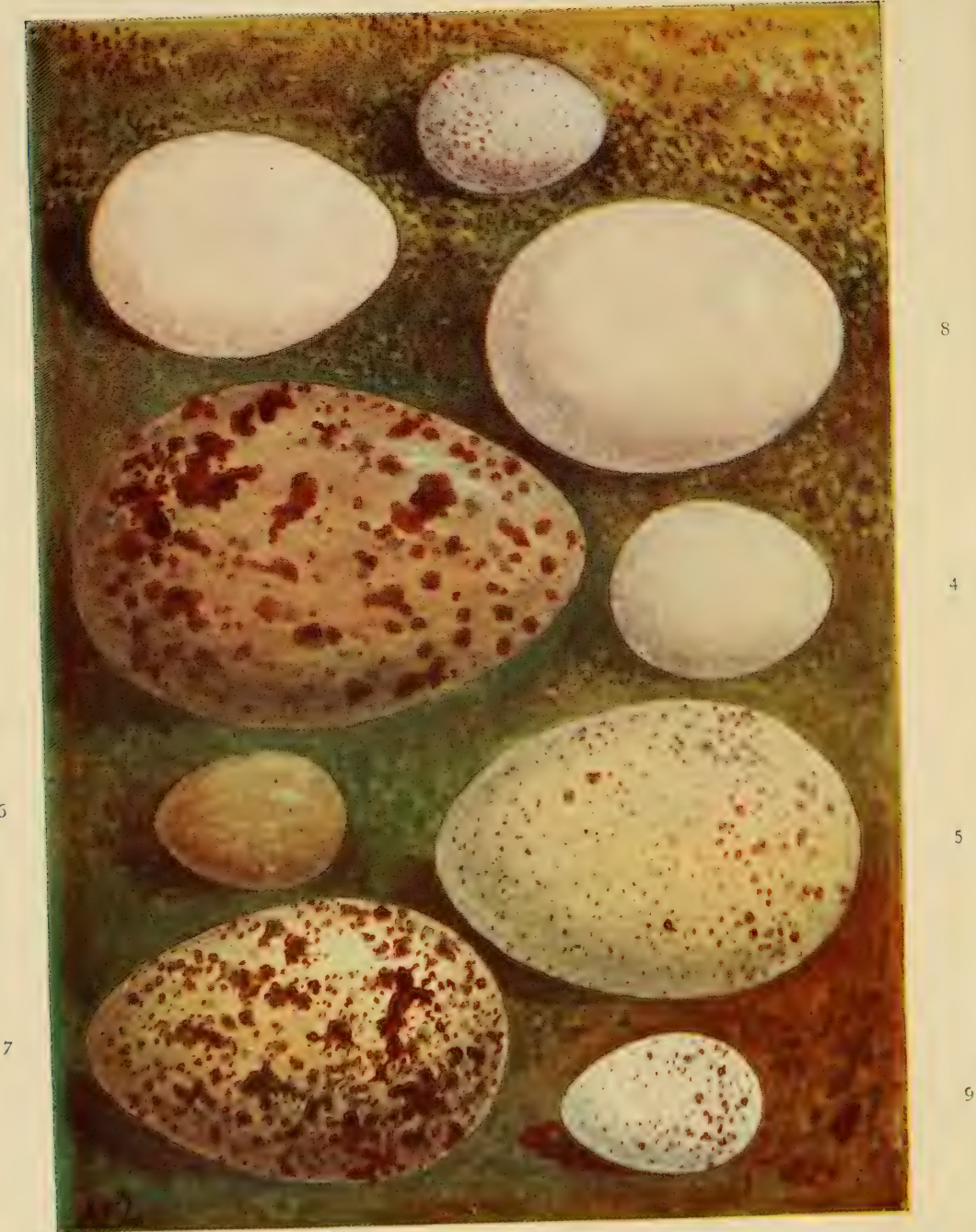

\section{EGGS.}

I. Nuthatch. 2. Sea Gull. 3. Woodpecker. 4. Kingfisher. 5. Moorhen.

6. Nightingale. 7. Lapwing. 8. Barn Owl. 9. Crossbill. 


\section{$\checkmark$ THE BLACKBIRD.}

The Blackbird builds her nest in stone walls, holly bushes, hedges, and amongst ivy. It is made with small twigs, roots, and cow-dung or clay intermixed, and lined inside with very fine slender grass. She has been known to try to build on the side of a cliff, where the sticks, \&c., would not remain, but have fallen down until there was enough to make half-a-dozen nests, yet the bird continued to bring fresh material. She lays four, five, and rarely six eggs of a dull bluish-green, spotted all over with brown blotches.

\section{$\sqrt{\text { THE GREAT TIT. }}$}

The eggs of this bird are from six to twelve in number; their colour is white, spotted with a reddish-brown. The nest is composed of moss, feathers, and hair, and is situated in holes in walls and trees. The bird has been known to make these holes herself in the trunk of a tree, working with great diligence and rapidity until she had finished.

\section{THE TEAL.}

Tre Teal builds its nest where rushes are abundant, chiefly on marshes in Scotland and the north of England. The nest is composed of large quantities of dried sedges, flags, and other water plants, and is lined with feathers. The bird lays eight or ten eggrs, which are buffish or creamy. white, sometimes faintly tinged with green.

\section{THE NUTHATCH.}

TrIs bird lays from five to seven eggrs in number, of a pure white spotted with red-brown. They are very often mistaken for the egrgs of the Great Titmouse. The nest 
is made of the dried leaves of the oak, apple, elm, \&c., carelessly arranged. It is situated in a hole of a decaying tree, and if too large at the entrance the bird plasters it up until she can just get in and out comfortably.

\section{THE COMIMON SEA-GULL.}

Thrs bird lays two, and sometimes three eggs, of a pale green or a yellowish-white colour, irregularly blotched with gray and blackish-brown. Her nest is made of seaweed, dry grass, \&c., and is found on sea cliffs and bold rocky headlands, such as St. Abb's Head in Berwickshire.

\section{$\sqrt{ }$ THE GREEN WOODPECKER.}

Ture eggs of this bird are three or four in number, of a very light bluish-tinged white colour. Her nest is made entirely of the pieces of wood chipped off by the bird in her boring operations. It is placed in the trunk of a tree, frequently in a hole which the bird herself has previously excavated, and perhaps used before. She secms to have a particular liking for the aspen and black poplar tree.

\section{THE KINGFISHER.}

Turs bird lays six or seven eggrs, nearly round, white and shining. When fresh and unblown, the yolk shows through the shell, and gives it a beautiful pink colour, something similar to the Dipper's, but more clear and vivid. The nest is composed of the bones of fishes, and is generally in the Sandmartin's previous excavations, about three or four feet above the usual surface of the water. 
$\checkmark$ THE IIOOR-HEN.

Tre eggs of this familiar and semi-domestic bird are from eight to ten in number, of a pale brownish-grey, spotted with umber-brown. This bird, like the duck, when leaving the nest covers her eggs with flags and reeds, of which also the nest is made. She builds among the sedges on the banks of streams and ponds, and sometimes in trees. Nests have often been found in willow-branches which touch and float upon the water.

\section{THE NIGHTINGALE.}

The eggs of this bird are from four to six in number, and are usually of a yellowish olive-brown colour, unspotted, but are occasionally found blue. Her nest is made of dried leaves, lined inside with fine grass. It is situated on the ground in woods and shrubberies, especially on the little banks at the foot of trees, under the shelter of ferns or weeds.

\section{$\int$ THE LAPIVING.}

Trre Lapwing, or Green Plover, makes a very simple nest, only scratching a hole and lining it with bent or short grass. She generally makes it on a little knoll, so that it may be out of danger of being deluged, as her home is generally in swampy marshy land. She lays four eggs of a dirty-green ground, blotched all over with dark brown spots, and the colour harmonises so well with the ground, that it is sometimes very difficult for the collector to see them even when looking close to where they are.

\section{THE BARN OWL.}

Tire Barn Owl lays two egggs at a time, that is, lays two and hatches them, and lays again, even to a second and 
third time, before the first have flown. They are white and unspotted. She makes a very slight nest of sticks, hay, and sometimes of her orwn cast-off feathers. She select barns, old ruins, hollow trees, and crevices of rocks, overshadowed by ivy or creeping plants.

\section{THE CROSS-BILL.}

Tris bird lays four or five eggs of a white colour, tinged with pale blue, resembling the colour of skim-milk, and speckled with red, but only very sparingly. Her nest is made of twigs, grass, and scmetimes lined with a few long hairs. She builds mostly among the branches of the Scotch fir, the nest being generally close to the boll or stem.

\section{THE WOODLARK.}

UNLIKE its congener, the Skylark, this bird is limited to certain localities in our islands. Whilst it is fairly abundant in some districts, it is seldom or never seen in others. It is highly esteemed as a song-bird, and consequently suffers at the hands of professional bird-catehers, especially as its young begin to carol at an early period of their existence. Its nest is situated on the ground, usually well concealed beneath a tuft of grass or low plant, and is composed of grass, bents, moss, and hairs, the coarser material used on the outside and the finer to line the interior. The eggs are four or five in number, of a lighter ground colour than the Skylark's eggs, thickly speckled with reddish-brown, the spots sometimes, but rarely, forming a zone at the larger end. 



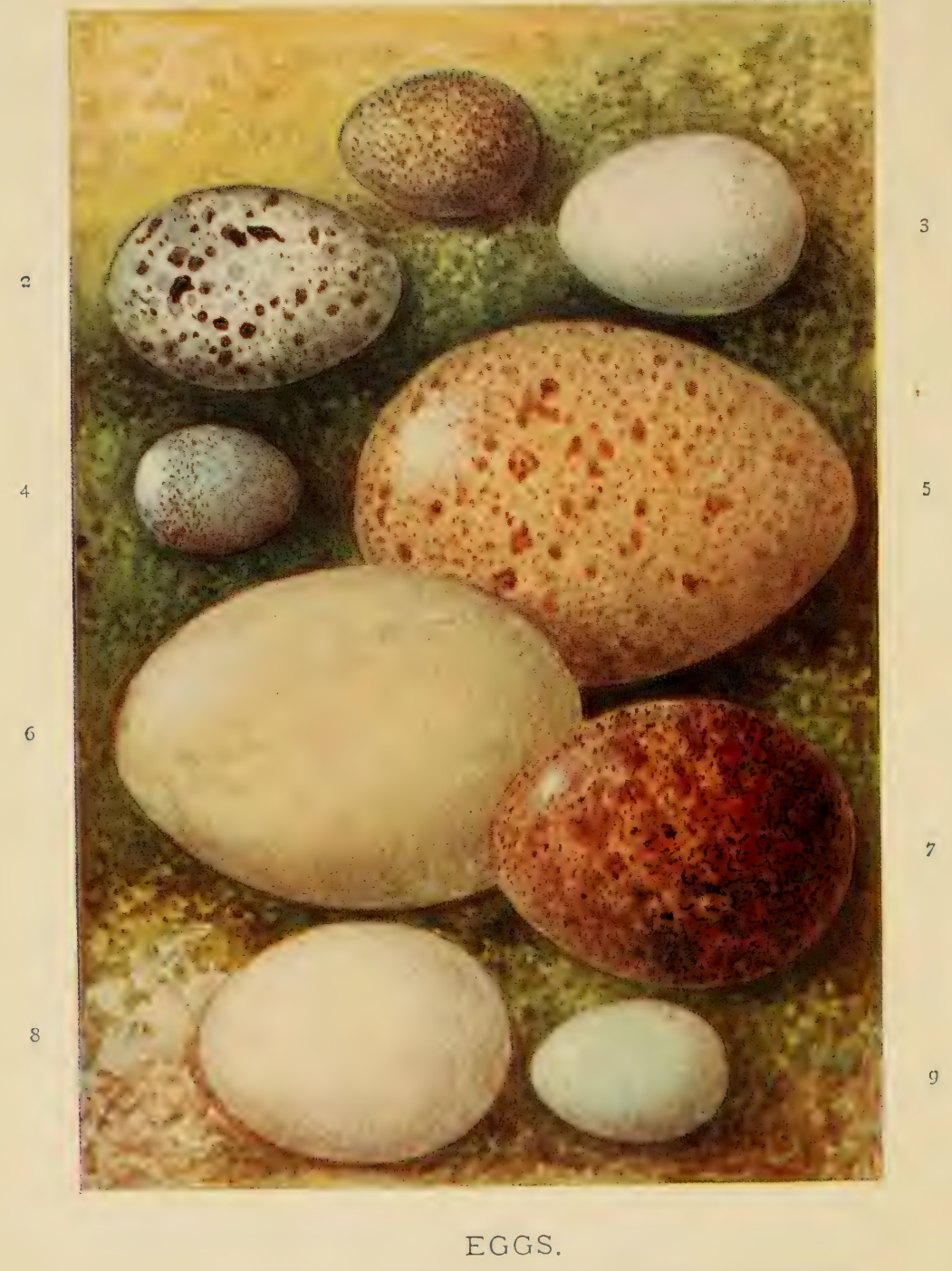

I. Woodlark. 2. Nightjar. 3. Stormy Petrel. 4. Stonechat. 5. Capercailzie.

6. Bittern. 7. Merlin. 8. Little Grebe. 9. Wheatear. 


\section{THE MERLIN.}

Like some other of the Hawks, the Merlin does not take much trouble in the construction of her nest, simply selecting a little hollow, usually well hidden by heather, in moorland districts, lining it with dead ling and a little grass. The eggs number from three to six, according to some authorities; but I have usually found four on the North Riding moors, brown in colour, thickly covered with spots, blotches, and marblings of a reddish hue, especially at the larger end.

\section{THE BIT'TERN.}

TuE ground is chosen as the situation of this bird's nest, well hidden amongst the dense growth of reeds and flags, in close proximity to the water it haunts. It is composed of a plenteous supply of sticks, reeds, flag-leaves, \&c. The eggrs are found in numbers of from three to five, and have been described as of a pale clay-brown, stone colour, and olive brown, all of which are as near the mark as a verbal description fan come.

\section{$\sqrt{\text { THE NIGHT-JAR. }}$}

THis bird cannot really be said. to make a nest of any kind, simply selecting some natural depression in the earth, beneath the shelter of a furze-bush or common bracken. She lays two eggrs, which are grey, beautifully spotted, and marbled or veined with dark brown and tints of a bluishlead colour, glossy. The female sits so closely, and harmonises so well with her surroundings, that, unless one happens to detect her beautiful large eye, the chances are very much against finding her nest. 


\section{THE STORM PETREL.}

Tre Scilly Islands, St. Kilda, the Orkneys, Shetland, and the Irish coast, are the breeding haunts of the Storm Petrel. The nest is placed on the ground, amongst cliffs and under large-sized stones, being composed of pieces of dry earth and stalks of plants. One single white egg, about the size of a Blackbird's, is laid.

\section{THE STONE-CIIAT.}

This pert little bird is very dexterous in the art of nestbuilding, selecting for materials moss and dry grasses to form the outer structure, and feathers, hair, \&c., for lining the interior. The position selected is generally on the ground, at the bottom of a furze-bush, though sometimes quite away from any bush. The eggs number five or six, and are of a pale blue-green, with minute reddish. brown spots, chiefly at the larger end.

\section{THE WHEAT-EAR.}

1 GHELTERED and darkened situation is generally chosen by the Wheat-ear wherein to build her nest-chinks of stone walls, the ruins of cairns, in old rabbit-burrows, under stones on moors, mountain wilds, \&c. The nest, not very artistic in construction, is composed of a variety of materials, such as bents, grass roots pulled up by the sheep when grazing, and dried in the sun, hair and wool gathered from brambles, corners of rocks, and walls against which the sheep have rubbed themselves. The eggs number five or six, and are of a pale greenish-blue colour unspotted. 

I

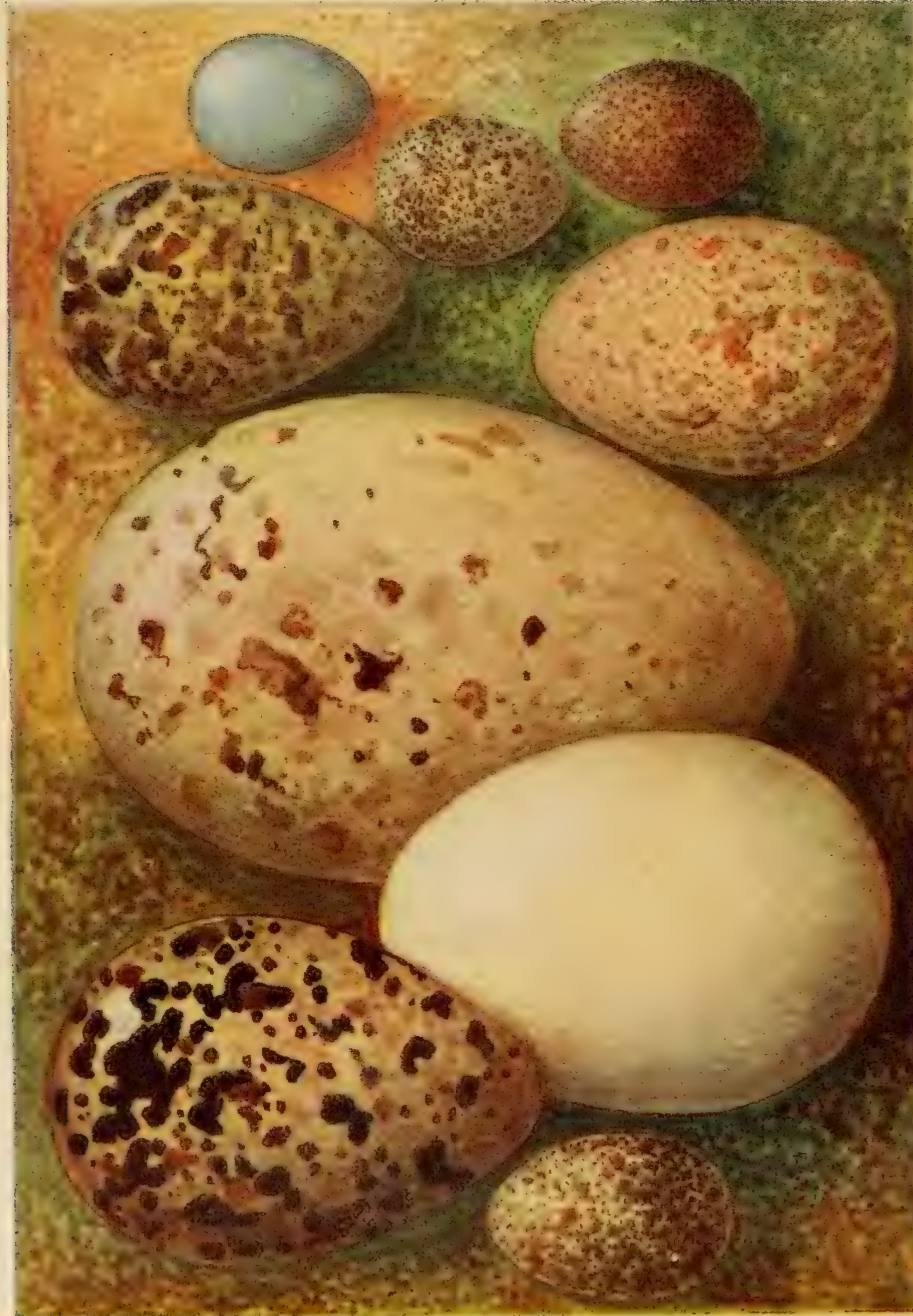

EGGS.

2. Pied Flycatcher. 2. Meadow Pipit. 3. Tree Pipit. 4. Dunlin. 5. Landrail. 6. Skua. 7. Wigeon. 8. Golden Plover. 9. Skylark. 


\section{$\sqrt{\text { THE LITTLE GREBE. }>}$}

An immense mass of aquatic weeds floating on the surface of a quiet pond, and thoroughly saturated with water, forms the nest of this birl. She lays from five to six egros, at first white, but gradually becoming dyed a dirty mud colour by the decaying weeds with which the parent bird covers them on leaving her nest to seek food, \&c.

\section{THE CAPERCAILZIE. $X$}

Trurs bird's nest is situated on the ground, and is composed of a few sticks and ling stalks. The eggs number from six to trvelve, and are of a pale reddish-yellow brown, spotted all over with two shades of darker orange-brown, somerwat like those of the Black Grouse.

\section{THE MLADOW PIPIT. $Y$}

Tre nest of this common little bird is built of bents, with an inner lining of grass and harrs. It is situated on the ground, and generally in such a position that protection from the rain, sheep's feet, \&c., is afforded by a stout tuft of bents, a projecting piece of earth or stone. Its where. abouts is, however, generally betrayed hy the parent bird's peculiar flight when disturbed, even in the earliest stages of incubation. In the course of a day's travel on the moors I have met with several nests, some of them remarkably close to each other. The egg's number from four to six; and in spite of the fact that some eminent authorities have said that they are of a redilish-brown, mottled orer with darker brown, varying but little, I should deseribe them as varying from light to very dark dusky brown. I 
should conclude, from long observation, that more Cuckcos are bred and reared by this bird than all the other fosterparents put together; and it is remarkable what affection it shows for the adopted nursling. Not long ago I had the misfortune to shoot a young Cuckoo during the dusk of evening in mistake for a Hawk, and was struck with pity on seeing the poor Meadow Pipit light on the dead body of the unfortunate victim, and try to drag it away as I approached.

\section{THE PIED FLY-CATCHER.}

This bird seems to resort annually to the same locality, and use the same nest year after year, which is composed of moss, grass, bents, feathers, hair, \&c., and is situated in holes in pollard-trees and walls. She lays four or five eggrs, of a pale blue, which might not erroneously be described as greenish-blue, unspotted.

\section{THE TREE PIPIT.}

The Tree Pipit's nest is always on the ground, beneath the shelter of a tuft of grass or low bush, and is made of fibrous roots, moss, and wool, lined with fine grass and hair. The eggs number from four to six, and are so variable in colour that verbal description is almost baffled in attempting to convey an impression of what they are like. Some are purple-red, thickly sprinkled with spots of a deeper shade; others of a yellowish-white, spotted and sprinkled all over with greyish-brown, like a Sparrow's egre.

\section{THE DUNLIN.}

Trie nesting-place of the Dunlin is on the sea-beach, among the shingle, heather, or long grass at the mouth of 
rivers, on moors and fells in the North of England, Wales, Ireland, Scotland, the Orkney Islands, and the Hebrides. The nest is composed of a meagre supply of bents and straws, and the eggs number four, elegantly shaped and beautifully coloured, though very variable in ground colour, sometimes of a bluish-white, blotehed all over with umber-brown, whilst others are of a clear light green, richly spotted with light brown. The hen sits closely.

\section{THE SKY-LARK.}

Tirs familiar songster's nest is placed on the ground, amongst corn or rough tufty grass, and its whereabouts is generally betrayed by the peculiar scudding flight of the hen when disturbed. The nest is built of bents and dry grass, those of the most slender texture being placed inside. The eggs number four or five (I have never found more), the colouring of which is subject to variation, and not of the easiest kind to convey in a written description. However, the following may be taken as representative:-A dirty white ground colour slightly tinged with green, spotted and mottled with umber brown, generally more thickly towards the larger end.

\section{THE GOLDEN PLOVER.}

The favnurite nesting-place of the Golden Plover is on the dreary mountain wilds of the North of England, Scotland, and Irelund. She selects a slight natural depression in the earth, and scrapes together bits of dead grass, rushes, and heather for a nest, in which four eggss are deposited, with the sharp points all meeting in the centre. The ground 
colour of the egrgs is stone or eream, spotted and blotehed with umber or blackish-brown, of various sizes and shapes.

THE LANDRAIL.

TrIe position selected by the Landrail for her nest is on the ground, amongst grass, underwood, clover, or corn. It is loosely constructed of dry herbage. Her eggs vary greatly in number, from seven, eight, or nine to as many as fifteen, and are of a dingy white, suffused with a reddish tinge, freckled and spotted with red, brown, and purplish-grey.

\section{THE WIGEON.}

This bird has been known to breed in Scotland and Ireland, but its favourite places are Scandinavia, Finland, and Northern Russia. The nest is placed in a clump of rushes or a tuft of heather, its materials being reeds and decayed rushes, with a beautiful inner lining of down off the parent birl, which lays from seven to ten creamy-white eggs, of a very oval shape. Broods have been hatehed at different times in the Zoological Gardens.

\section{THE COMIION. STUA.}

Nidification is carrice on by the Skua in companies, in the Shetland Islands only. The nest is placed on the ground, and. is made of dead ling, moss, and dry grass, in which are deposited two eggs only, of varying colour. Some are of a dark olive brown, whilst others are of a greener tint, with black-brown spots, intermixed with small speckles of a whitish or rusty colour. 



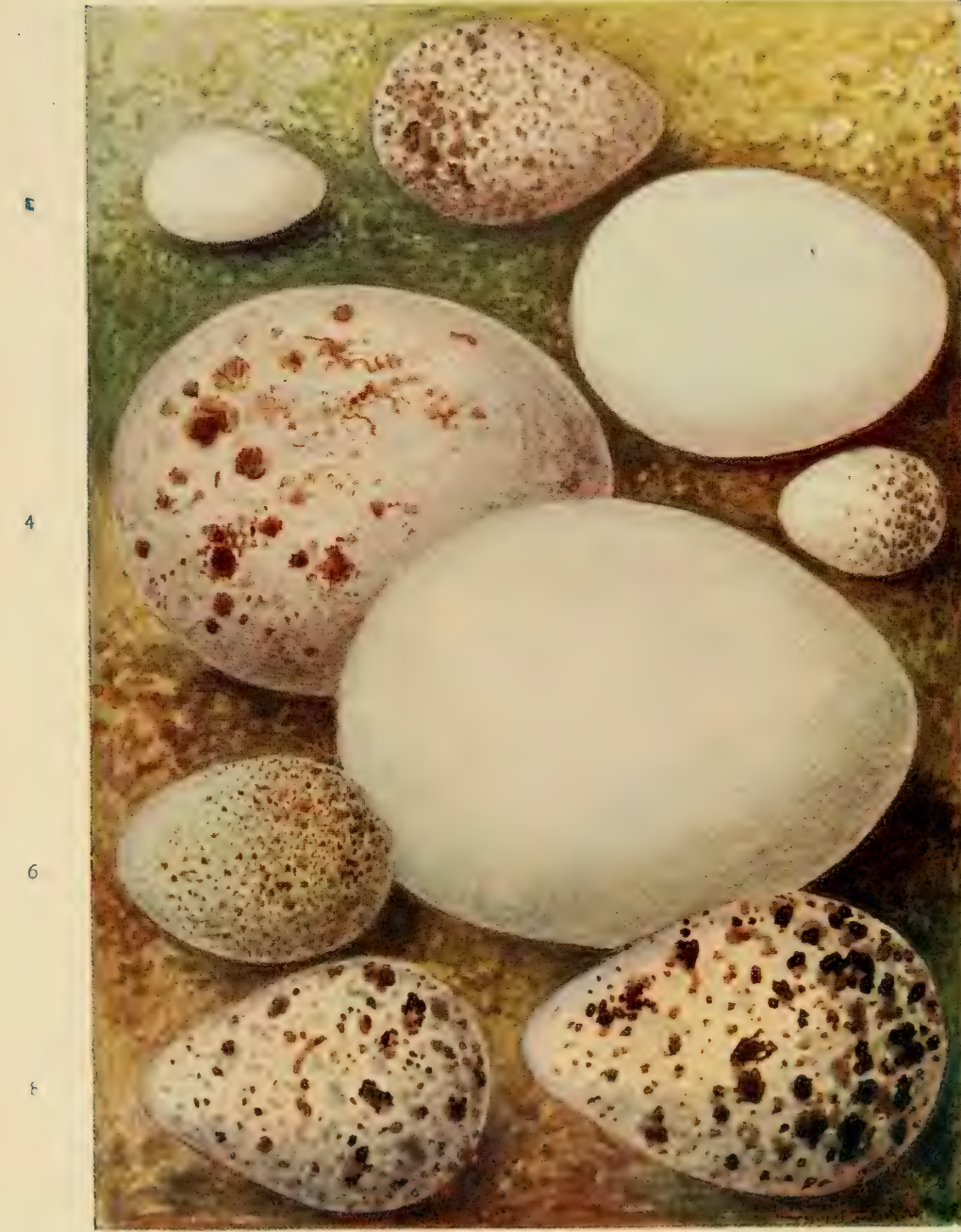

\section{EGGS.}

1. Sand Martin. 2. Little Stint. 3. Long-eared Owl. 4. Kite. 5. Lesser White-throat 6. Redwing. 7. Shieldrake. 8. Sandpiper. 9. Redshank. 


\section{THE KITE.}

THIs bird locates its nest in a strong fork of some tall tree, building it with sticks and whatever softer material she can come at without much trouble, such as wool, \&c. The eggrs number three, and are of a grey or dirty white, spotted and blotched with duil red or orange-brown, the spots predominating at the larger end.

\section{THE RED-SHANK.}

T'HE nest of the Red-shank is situated amidst a tuft of grass, or in a small hole sheltered by the surrounding herbage, and is constructed of a few blades of fine dry grass lightly put together. She lays four eggrs of a cream or straw colour, blotched and speckled with dark brown, the spots being very variable, but generally forming a belt or zone at the larger end.

\section{$\checkmark$ THE SAND-MARTIN.}

As denoted by the name, the nesting-place of the Sandmartin is at the extremity of a deep hole, which the bird excavates for herself in some sandbank, generally near a river. The nest is constructed of straw, hay, or dead rushes, whichever may be found in the locality where the bird is breeding, and lined with feathers. The eggss are from four to six in number, of an elongated shape, the extreme thinness of the shell giving them a pinky appear. ance, but when blown they are a beautiful white.

\section{THE LITTLE STINT.}

This bird does not breed in the British Isles, but in Northern Europe and Asia. The nest is situated un the ground, and is very similar in construction to that of most 
of the Sandpiper species, being a natural depression in the ground, with a lining of dead leaves, or other such material as may be procured within easy reach of the place chosen. The eggs are four in number, of varying ground colour, from pale brown to pale greenish-grey, spotted and blotched with rich brown, the spots generally confluent at the larger end; but the colour is probably subject to as many zariations as the Dunlin's eggs, already described.

\section{THE LONG-EARED OWL.}

LiKE the Hawk tribe generally, this bird manifests an unmistakable dislike for maternal labour, as she contents herself with the old nest of a Crow, Magpie, or the abandoned home of a Squirrel. Some collectors give the number of eggs as from three to seven; but four or five is the general rule, and numbers above the last figure quoted the exception. The eggs are white, and almost as blunt at one end as the other.

\section{THE SHIELDRAKE.}

The labours of the Rabbit are utilised by the Shieldrake, and almost indispensable to her for incubation purposes, as she deposits dried flags, bents, reeds, and a liberal quantity of down, plucked from her own body, at the bottom of a deep burrow, after having enlarged and improved it to suit her purpose. She lays from eight even to twice that number of eggs, of a very smooth, roundish, oblong shape. They are cream colour, or nearly wbite in colour.

\section{THE REDWING.}

THIS bird very rarely builds in the British Isles, but abundantly in Norway, Sweden, and other high latitudes 
visited by it during the summer. Its nest is very similar to that of the ordinary Ring Ouzel or Blackbird, and is located in the middle of a dense bush. The eggs number from four to six, and are somewhat like those of the Fieldfare, only not so large. It would take a very clever connoisseur to pick out the egg of the Blackbird, Ring Ouzel, Fieldfare, and Rediving from some specimens without making a mistake, so much alike are they in colour, size, and shape.

\section{THE SANDPIPER.}

$\mathrm{O}_{N}$ the banks of a river, lake, or tarn, this familiar little bird locates its nest, generally choosing some natural de. pression, where it will be protected by a projecting grass tuft, though I have found its nest on the bare ground, and once on a tiny piece of grass amongst a lot of rocks. The nest is lined with dead rushes, leaves, and fine grass. The eggs number four, of a creamy yellow or stone colour, with light brown spots and blotches, as it were, in the shell, and dark brown on the surface.

\section{$\checkmark$ THE LESSER WHITE-THROA'T.}

THe situation chosen by the Lesser. Whitethroat for its nest is amongst brambles, low bushes, and nettles, building it of grass, bents, and an inner lining of horsehairs. The eggs number four or five, and are white, with a greenish tendency, spotted, chiefly at the larger end, with ash and light umber brown.

THE RUFF.

This bird, like the Snipe and Red-shank, malies her nest in wet, swampy places, using only the coarse grass found on 
the spot. Like its congeners, it only lays four eggs, very similar in ground colour and marking to the two birds quoted above, varying from stone-colour to olive-green, blotched and speckled with rich brown and liver-coloured spots.

\section{THE WHITE-TAILED EAGLE.}

THe high, inaccessible cliffs of Scotland and Ireland are the places where this noble bird propagates its race. Sticks, heather, grass, and wool are the nesting materials used. The eggs are two in number, usually of an unspotted white as representative, but sometimes slightly marked with pale red-this, however, being the exception.

\section{THE GREY PHALAROPE.}

The breeding haunts of this bird seem to be as far north as it can possibly carry out incubation successfully ; Greenland, Northern Siberia, and Melville Island being chosen. A natural depression in the peat earth serves as a nest, in which four eggrs are usually laid, of a stony colour, tinged with olive-green, speckled and spotted (especially at the larger end) with dark brown.

\section{THE SHOVELLER.}

Tins duck breeds in Norfolk, the Fen districts, and Scotland, once numerously, but now more rarely. The nest is made in marshes as far removed from human intrusion as possible, and is constructed of sedges, reeds, \&c.; and as the time of hatehing aplroaches, the eggrs are covered with down from the bird's orwn body. They number from eight to twelve, and are white, tinged with green. 



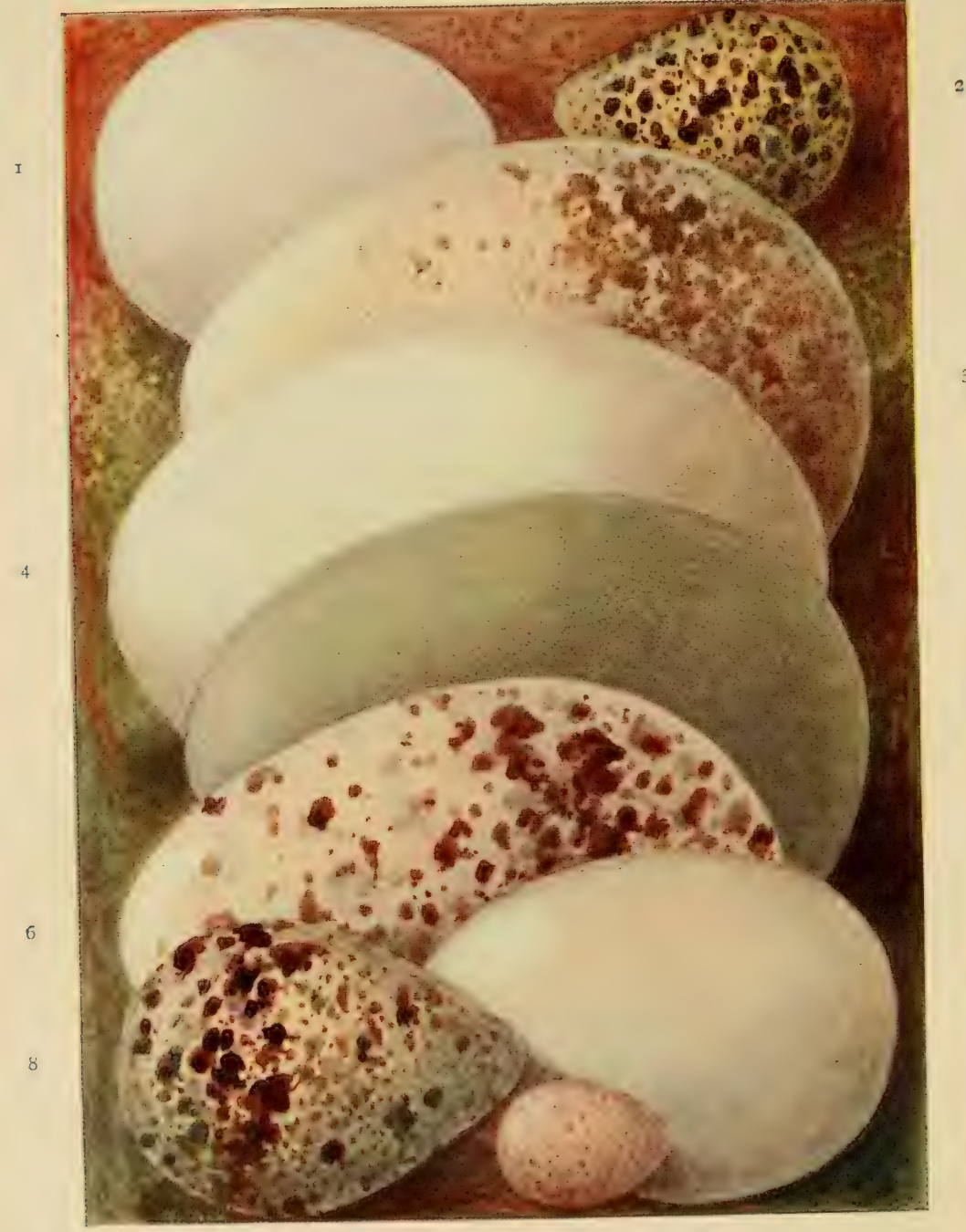

\section{EGGS.}

1. Tawny Owl. 2. Grey Phalarope 3. Golden Eagle. 4. White-tailed Eagle.

5. Eider Duck. 6. Herring Gull. 7. Shoveller. 8. Ruff. 9. Grasshopper WVarbler. 
THE GRASSHOPPER WARBLER.

THE nest of this shy little summer visitor is usually well concealed near the ground, in the midule of a thick bush. It is constructed of strong dry grass and moss outside, with an inner lining of slender grass. The eggs number from four to seven, and are of a pale rosy-coloured white, with spots and speckles all over of a darker-shaded red.

\section{THE GOLDEN EAGLE.}

The mate of this king of birds builds her nest in the most desolate and unapproachable parts of Scotland and Ireland, where even the skilful and daring cragsman can with difficulty come. The eyric is made of sticks, a supply being added each year until an enormous pile is collected, almost flat at the top. The eggs number from two to three, and are of a grey or dingy-white colour, clouded and blotched nearly all over with rusty or reddish-brown spots.

\section{THE EIDER DUCK.}

Tins useful member of the Duck family breeds on the Scottish coast and at the Farne Islands, and on the shores of Norway and Sweden, in great numbers. The nest is made of dried grasses, weeds, \&c.; and as the process of incubation advances, like the Shoveller, the mother lines the nest profusely with the beautiful down from its body. The eggs usually number five, and are of a light green colour, oblong in shape.

\section{$\checkmark$ THE TAWNY OWL.}

A HolLow in a tree, or the deserted nest of a Crow, serves this nocturnal bird for a nest. The eggrs are of an 
elliptical shape, numbering from three to five, and are quite white.

\section{$\int$ THE HERRING GULL:}

$S_{\text {EA }}$ cliffs and rocky islands round the coasts of England, Wales, Scotland, and Ireland, are the nesting-places of this bird, the materials used being dried grass and ferns, loosely put together. The eggs are three in number, of a stone colour, sometimes light olive-brown-but this rarelyspotted with dark brown.

\section{$\checkmark$ THE CARRION CROW.}

Tiris bold predatory bird is like the Raven, monogamous, and sticks to its mate for life. They use the same nest often year after year, driving their young forth as soon as they are capable of looking after themselves. On an average four or five eggs are laid, of a grey-green colour, blotched and spotted with a smoky brown. In some instances, like those of the Rook, they are found quite blue, minus spots. The nest is situated at the tops of trees in woods or plantations, and is composed of sticks like those of most birds, using the larger for the outside, the smaller for the inside, which is plastered with mud, clay, or cow-dung, lined with wool, horse and cow hair.

\section{$\sqrt{\text { THE SWALLOW. }}$}

I HAVE observed that the Swallow's favourite nestingplace is amongst the rafters of cow-barns, stables, and cut-houses of a similar nature. Nests may be found 



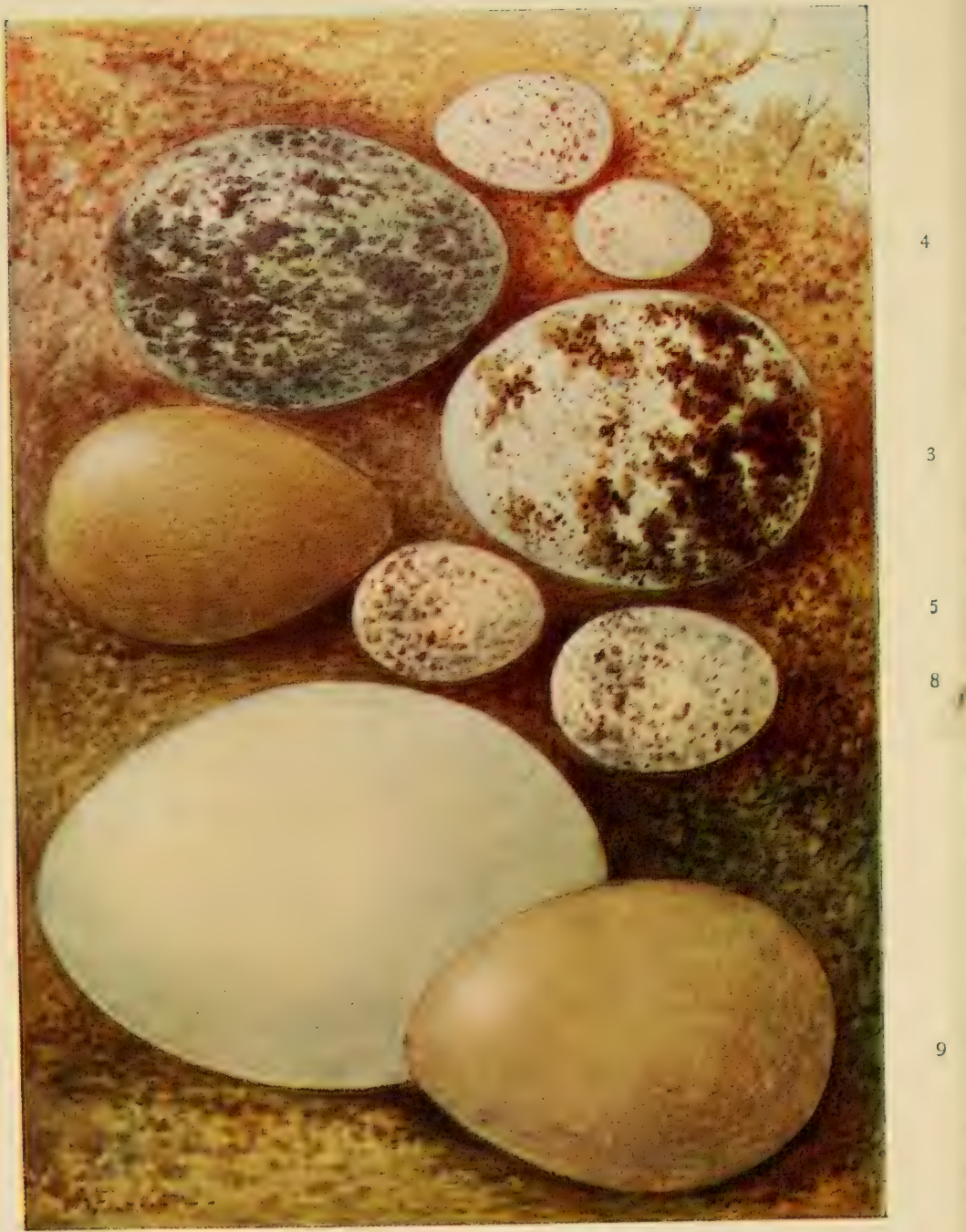

EGGS.

1. Carrion Crow. 2. Swallow. 3. Sparrow-Hawk. 4. Blue Tit. 5. Blackcap. 6. Partridge. 7. Wild Duck. 8. Cuckoo. 0. Pheasant. 
even in old chimneys, but it is my opinion that they only locate themselves in such a smoky atmosphere when no better place is procurable; they have also been found amongst the brickwork of disused limekilns. The nest is composed of clay or mud mixed with straw, hay, and rushes, lined with soft light feathers, usually gathered whilst the bird is on the wing. When a boy, I have amused myself for hours flying feathers for the dexterous Swallows and Martins to carry off to their nests, and have always observed that if the Swallow let a feather fall from her nest whilst building it, and did not catch it before reaching the ground, she allowed it to remain there, often to betray the locality of her eggrs. The Swallow does not exhibit the same amount of care over the formation of her nest as the Common Martin or Sand Martin, and leaves it open at the top. She lays four or five eggs, white, which are unlike those of the other species of the family, inasmuch as they are speckled with brown, which generally forms a belt round the larger end of the egg.

\section{$\int$ THE SPARROW-HAWK.}

The Sparrow-Hawk lays from four to six egegs of a bluishwhite, spotted more numerously at the larger end with red-brown blotches. It is said to often utilise the disused nest of the Magpie or Crow, but I am inclined to the opinion that this is not often the case, as the half-score or so of nests which have come under my personal observation have in every instance been built by the Sparrowhawk herself. 


\section{THE BLUE TIT.}

Buue Trits lay from seven to nine eggs, of a white underground, spotted with red-brown all over, but more numernusly at the larger end. Their nests are composed of moss, feathers, and hair, and will generally be found in holes in trees or walls.

\section{THE BLACKCAP.}

The Blackcap locates her nest amongst nettles and brambles, generally near the ground, but not resting upon it. It is a very slovenly bird, as far as the structure of its nest goes, which is composed of fibrous roots and the stems of cleavers. It lays four or five eggs of a whitish underground, blotched and spotted, with two shades of brown or pale delicate pink, with dark red spots and blotches.

\section{$\checkmark$ THE PARTRIDGE.}

Frow ten to twenty eggs are laid by the Partridge, of a pale yellow-brown, without any spots. There has been some diversity of opinion as to the time of hatching, some holding that the third week of June is the time, whilst others say the middle of the following month; but I think that the locality in which the bird is found has something to do with this difference of time. She does not make any nest worth speaking about, merely scratching and trampling the grass, weeds, \&c., down. Her nest is situated on the ground in standing grass, cornfields, among brackens, weeds, \&c., mostly in arable districts 
She sits very closely, indeed so closely that I have known her head cut clean off as she sat on her nest in a field of grass which was being mown.

\section{$\sqrt{\text { THE WILD DUCK. }}$}

Trie nest of the Wild Duck is composed of grass, intermixed and lined with down, and is generally situated on the ground near the margin of rivers or lakes, to enable the mother to lead her progeny to the water immediately they are hatched. However, there are numerous exceptions to the usual site of her nest, as it is occasionally found occupying deserted Crows' nests, or built on pollard willows, and has even been found in such an exceptionally odd situation as a church tower, from whence she managed to convey her young in safety. These elevated nestingplaces have given rise to mucl variance of opinion amongst naturalists as to how the parent bird carries her progeny to the water; some contending that she conveys them in her feet, others, in her beak, \&c.

This habit of the lird, however, is quite familiar to the Laplanders, who prepare wooden cylinders, which they stop at each end, leaving a hole in the side, and elevate on poles, to entice the duck, which does not hesitate to avail itself of such convenient accommodation; thus the wily Laplander is enriched with a good store of egg's for breakfast. The Hawk-Owl often takes a fancy to the situation, and appropriates it for nidification purposes, paying dearly for his intrusion when the owner of the cylinder comes round to collect his dues.

The eggs of the Wild Duck number from eight to fifteen, of a greenish-white colour, smooth on the surface. 
$\checkmark$ THE CUCKOO.

The Cuckoo seems to think he was born to do nothing else but tell and re-tell

"His name to all the hills;"

for he neither makes a nest nor troubles to rear his young, but leaves them to the tender mercies of unpaid nurses, being partial to the Wagtail, Hedge-sparrow, and Meadow Pipit, who are so affectionate that they have been known to follow and feed the young Cuckoo in a cage. Only one egg is found in a nest, which is of a reddish-grey, with a darker belt formed of numerous confluent spots at the thick end of the egg, but they are very variable.

\section{$\checkmark$ THE PHEASANT.}

Pheasants lay from eight to thirteen eggs of a pale olivegreen or brown, without spots. Their nests are composed chiefly of the dried grass where it is situated, which is on the ground amongst weeds, coarse grass, or scrub, in the outskirts of woods. It has, however, been found occupying a Squirrel's drey in a Scotch fir, where she hatched her young, but did not rear them, as from some cause or other they died in the nest. This bird is polygamous.

\section{$\sqrt{ }$ THE PIED WAGTAIL.}

THE nest of this bird is situated in holes in stone walls, bridges, crevices of rocks, quarries, \&c. I remember on 



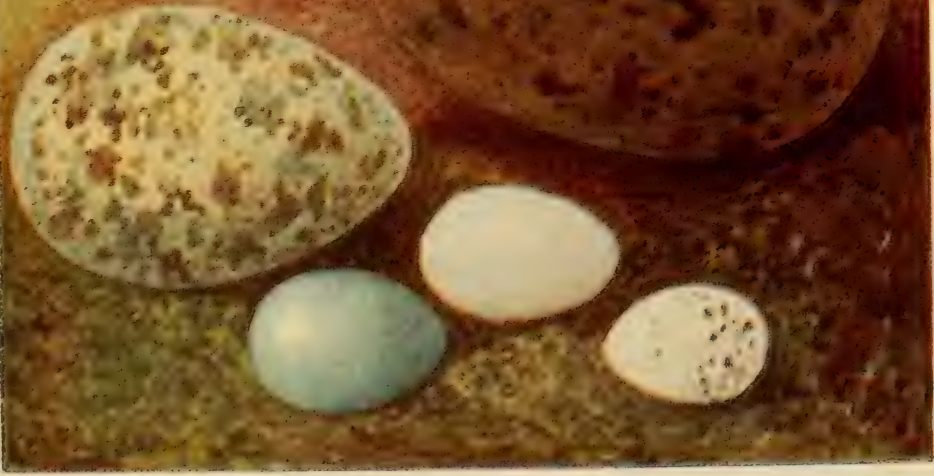

\section{8 \\ EGGS.}

I. Pied Wagtail. 2. Heron. 3. Woodcock. 4. Swift. 5. Black-headed Gull.

6. Snipe. 7. Chiff-Chaff. 8. Martin. 9. Hedge Sparrow. 
one occasion finding one in the stump of a rutten tree which had broken off about eleven feet from the ground; they are also found in pollard willows. The nest is chiefly composed of moss, small fine grass, fibrous roots, wool, horse and cow-hair. The eggs number from four to six, and are of a grey colour, speckled with light umber-brown.

\section{$\checkmark$ THE HERON.}

The Heron lays four or five eggs of a pale blue, with a tinge of green. Her nest is composed of a very liberal collection of sticks, and is lined in the interior with wool, and occasionally rags. It is situated on the tops of high trees. Like the Rooks, Herons build in societies, which are called heronries.

\section{THE WOODCOCK.}

THE Woodcock lays four eggs of a yellow-white colour, blotched with pale chestnut-brown. Her nest is generally found amongst the underwood at the foot of a tree, where she does not appear to try to avoid its being seen, but scratches a slight hollow, lining it with dead leaves and the withered fronds of the bracken. Although the great bulk of these birds are migrants, it is nor proved beyond doubt that many are bred yearly in this country. Like the Partridge, Grouse, \&c., the young leave the nest as soon as hatched, and are most carefully looked after by the parent bird. 
'THE SWIF'T.

The Swift is the garret-lodger of nature, for she builds her nest in the very highest crevices and holes in steeples, towers, chimneys, rocks, and occasionally, like the Martin, under the eaves of inhabited houses. Her nest is composed of hay, straw, and feathers, in somewhat sparse quantities, which she appears to solder or cement to the stone and to each other with a glutinous substance elaborated by glands peculiar to certain birds of this genus. She lays two or three white unspotted eggs of a rather long oval shape.

\section{THE BLACK-HEADED GULL.}

This bird generally lays three eggs, four being occasionally found, of a pale olive-green or pale umber-brown, blotched with black-brown or dark grey; however, they are very variable in ground colour, sometimes being of a bluish-white, unspotted. The nest is loosely built of the tops of sedges, reeds, or rushes, and is placed about a foot or more above the surface of the water or swamp. She is fond of low marshy districts, such as Norfolk, Kent, Essex, and some parts of Lincolnshire, and I have frequently found her round the edges of high mountain tarns in the Pennine range.

THE SNIPE.

The Snipe generally lays four eggrs, rather large for her size, of a grey colour, tingred with yellow or olive-green, and blotched with umber or rusty brown, of two shades, 
more thickly towards the larger end. The eggs are sharply pointed, and invariably placed with the small ends together in the middle. Her nest is placed in a slight depression in the earth, which she lines with withered grass, rushes, or dried heather. It is situated in long grass: rushes, or amongst heather, near to tarns, swamps, bogs, and other places suitable to the habitat of the bird.

\section{THE CHIFF-CHAEF.}

This bird lays five, six, or seven eggrs of white ground, dotted with brown or blackish-purple spots, predominating at the larger end ; the shell is very delicate, and must be carefully handled. Her nest is built of dead grass, the skeletons of leaves, tinin pieces of bark and moss, lined profusely inside with wool, feathers, and hair. It is situated amongst furzes, brambles, in hedge-banks near the ground, occasionally amongst long grass on the ground, and is spherical in shape, with an opening at the side.

\section{$\checkmark$ THE MARTIN.}

TII Martin seems particularly fond of attaching her nest to the habitations of man. I have counted eighteen nests in as many feet under the eaves of one house. She builds under eaves, angles of windows, arches of bridges, throughs of cow-barns, rocks, sea-cliffs, \&e. Her nest is comprosed of clay and mud, particularly that found on roads corered with limestone, as it possesses great adhesive qualities 
when dry. If the weather is dull it takes her some time to build her nest, but if it is dry and fine she runs it up quickly, working most dexterously at it early in the morning. She lines it internally with straw, hay, and feathers, and returns to the same nesting-place year after year, sometimes to find her cosy little nest occupied by sparrows. She lays four or five eggs, white, the yolk giving them a slight pinky tinge, unspotted.

\section{$\sqrt{\text { THE HEDGE-SPARROW. }}$}

The Hedge-sparrow's favourite nesting-place is in hawthorn hedges, the nest is also found in furze-bushes, low shrubs, laurels, \&c., and is composed of straw, dried grass, moss, and wool, lined with hair. The eggs are four or five in number, of a beautiful greenish-blue.

\section{THE DIPPER.}

The Dipper, or Water Ouzel as it is called in some districts, builds her nest in such splendid harmony with its surroundings that it is very difficult to find. It is generally placed near to some waterfall, and very often behind it, so that the bird has to fly through the water on entering and leaving her nest It is also found in caves, underneath the arches of bridges, and I have even found one in a tree. The exterior is composed of aquatic mosses, and the interior beautifully lined with dry leaves. Dippers' nests are 



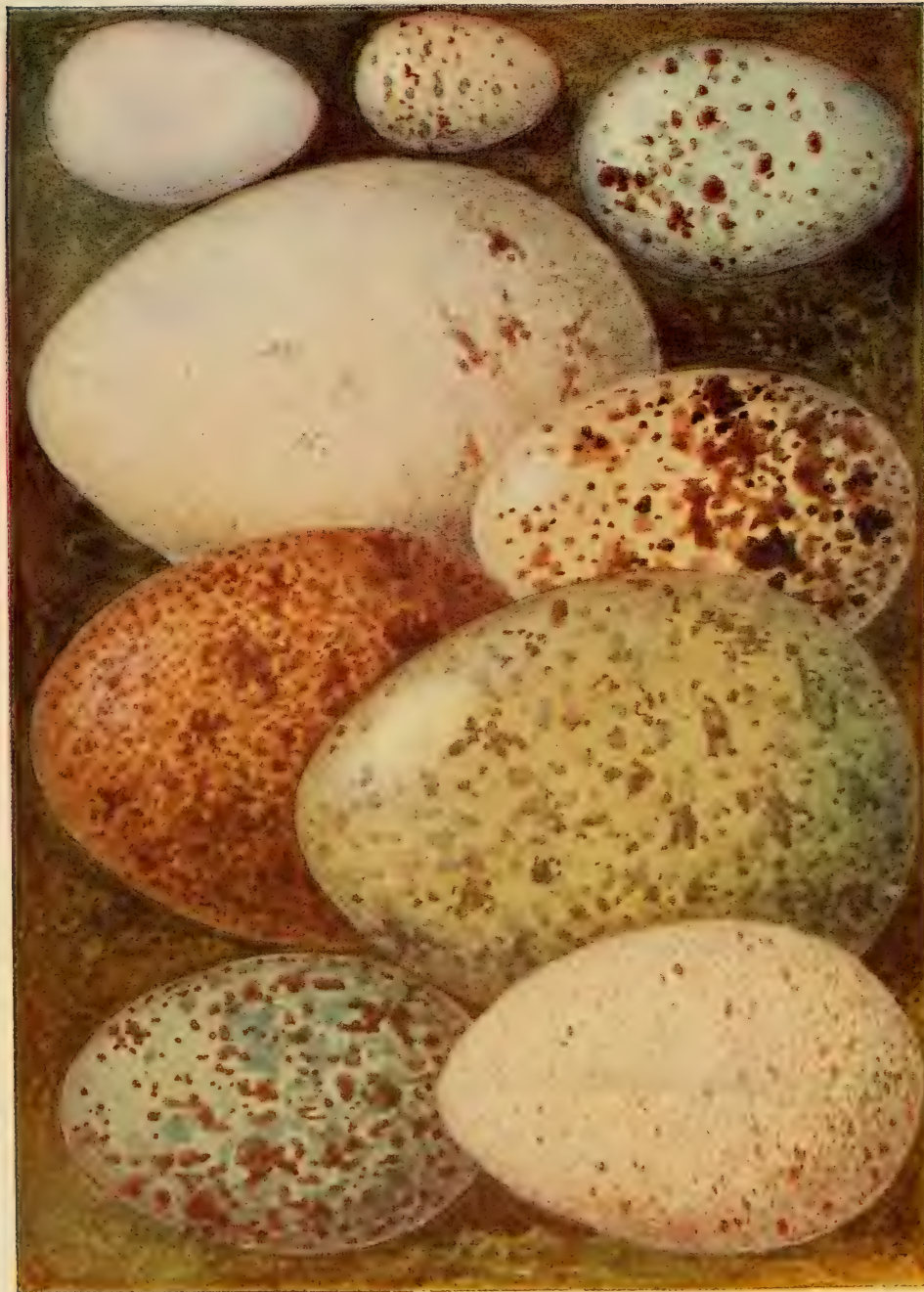

\section{EGGS.}

I. Dipper. 2. Garden Warbler. 3. Missel Thrush. 4. Spoonbill. 5. Ftarmigan. 6. Peregrine Falcon. 7. Curlew. 8. Hooded Crow. 9. Coot. 
generally of large size, almost globular in form, with a central hole for the entrance and exit of the bird. She lays from four to six eggs, the average being five, of a delicate semi-transparent white, unspotted.

\section{THE GARDEN WARBLER.}

The Garden Warbler's nest is located a few feet from the ground, in the branches of a thorn or bramble-bush, and coarse grasses, which are densely matted. It is made of straws, dried grass, fibrous roots, wool, and horse-hair, and is rather loose and slovenly. Her eggs number four or five, of a pale yellowish stone-grey, blotched and spotted with ash-grey and purplish-brown.

\section{$\sqrt{ }$ THE MISSEL THRUSH.}

THis bird, known in many parts of the country as the Misseltoe Thrush, builds her nest in trees, resting it on a branch close to the trunk, or where the trunk ends abruptly in two or three strong branches. It is composed of dried grass and moss, with a liberal mixture of wool, which helps it to adhere to the bark of the tree, and is lined internally with fine soft grass. Her eggs number from four to six, according to some authorities, of a pale green, speckled with brown, of two shades; however, the colours are subject to variation. She commences to breed very early in the season, like the Common Thrush, and has been known to lay trice in the same nest, which strengthons my opinion that the bird does often rear two broods in one 
season, from the time I have known her to occupy the same nest.

\section{THE SPOONBILL.}

Tire Spoonbill lays from two to four eggs, which vary in colour, some being entirely white, whilst others are spotted with a light brownish-red. The nest is situated in trees, or amongst the reeds and rushes on the ground, the bird seeming, like the Heron, partial to society. If the nature of the position will permit, several nests are situated close together, and are composed of sticks, coarse grass, and dried roots, carelessly thrown together. The bird does not breed in this country.

\section{THE PTARMIGAN.}

This bird lays from six to fifteen eggs of a pale red, brown or white, blotched with two shades of darker brown. Her nest is situated on the ground, on the bleak stony mountain-tops of the mainland of Scotland and the surrounding islands. It is merely a cavity scratched in the ground, in which the hen lays her eggs.

\section{THE PEREGRINE FALCON.}

Turs noble bird builds her nest of sticks, and places it amongst rugged cliffs, chiefly round the coast. She lays three or four eggs of a red-brown colour, with darker blotches and clouds. 


\section{THE CURLEW.}

OF slight construction, the nest of this bird is situated on moorland, heath, and marsh tracts of land; a few leaves or other dry materials, carelessly brought together among long grass, heather, or in a tuft of rushes, is all that appears. The eggs are four in number, pear-shaped, and generally placed with the smaller ends together, of an olive-green colour, blotched and spotted with darker green and dark brown.

\section{THE HOODED CROW.}

Hooved Crows lay four or five eggs of a grey-green, blotched and spotted with smoky brown. Their nests are built of sticks, heather, and wool, and are situated amongst rocks and sea-cliffs in Scotland, occasionally in trees, and are very similar to those of the Carrion Crow.

\section{$\sqrt{\text { THE COOT. }}$}

Tire Coot lays from seven to ten eggs, of a dingy stone colour or dull buff, spotted and speckled with brown; the spots are less numerous but darker than the speckles. Her nest is situated in marshes and ponds, and is composed of decaying sedges, reeds, flags, and rushes; and, though of clumsy appearance, is very strong. It is built on willows that grow amongst the water, on tufts of rushes, and more commonly among reeds. It has been known to be dislodged from its position by a flood, and swept ashore 
whilst the lird was incubating without any apparent inconvenience to her.

THE WATER RAIL.

As might be expected, the nest of this bird is composed of sedges and flags, in somewhat considerable quantities, and is situated under thick cover in osier-beds and swamps in which alders grow, more especially in the southern counties of England. The hen lays from six to nine eggs of a creany-white, with a few small reddish spots and dots.

\section{THE COMMON BUNTING.}

Tue Common Bunting lays from four to six eggs of a grey colour, tinged with red-brown, purple-brown, and ashcoloured spots or streaks. Her nest is built of straw and coarse hay outside, lined in the interior with fibrous roots, and sometimes with horse-hair. It is situated amongst coarse grass near to or on the ground.

\section{$\sqrt{\text { THE YELLOW-HAMMER. }}$}

Trrs beautiful bird lays from three to six eggs of a dingy white tinged with purple, streaked and veined with purplebrown, the streak or vein generally terminating in a spot of the same colour. Her nest is situated on or near the ground, sheltered by overhanging grass, and is composed of dried or decayed leaves of grass round the exterior, followed 



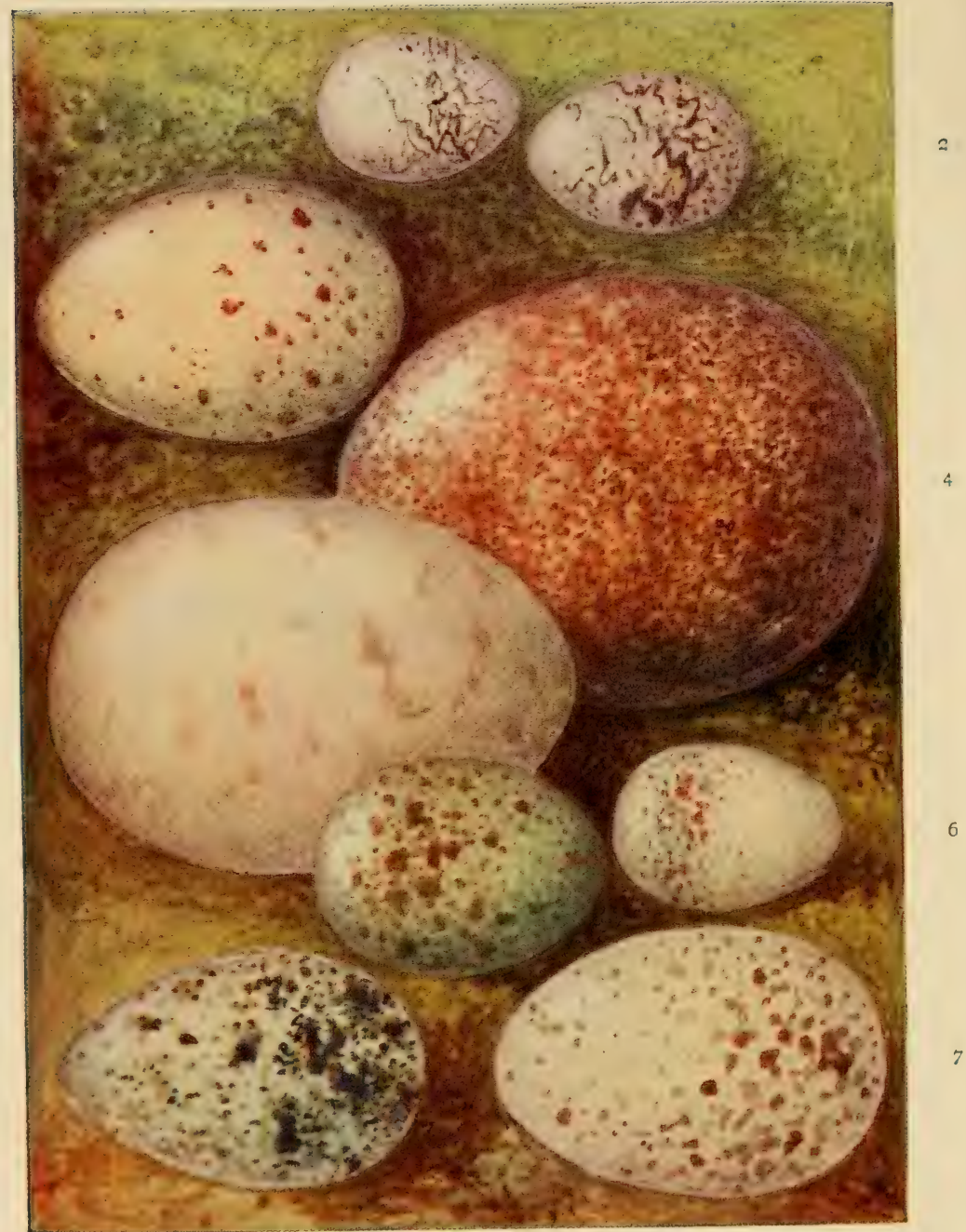

\section{EGGS.}

I. Water Rail. 2. Common Bunting. 3. Yellow Hammer. 4. Gyr-Falcon.
5. Jack Snipe.
6. Red-backed Shrike. 7. Chough.
8. Fieldfare
9. Puffin 
by a layer of finer grass, and the interior lined with horsehair.

\section{THE JACK SNIPE.}

According to some of the very best authorities on British ornithology, the Jack Snipe does not breed in these islands although an occasional nest is said to have been found. The bird is only a winter migrant, and breeds in the neighbourhood of St. Petersburg. The eggs are four in number, of a yellowish olive colour, spotted with two shades of brown, especially on the larger end.

\section{THE GYR FALCON.}

Trie Gyr Falcon does not build in the British Isles, but in Iceland, Greenland, and the northern districts of Europe and America. The nest is composed of sticks, seaweed, and mosses, and is situated in lofty precipices. The eggs are two in number, mottled nearly all over with pale reddish-brown on a dull white ground. They are larger than those of the Peregrine Falcon, but very similar in shape and colour, as well as in the mode in which the colour is disposed over the surface.

THE FIELDFARE.

A Fieldfare's nest has never, within my personal knowledge, been found in the British Isles, the birds breeding in the more northern parts of Europe, such as Norway and 
Sweden, in large number's. They build their nests near to the trunks of spruce trees, employing such materials as sticks and coarse grass, and weeds gathered wet, intermixed with clay, and lined internally with long grass. The eggs number from three to six, somerwhat resembling those of the Blackbird or Ring Ouzel.

\section{THE RED-BACKED SHRIKE.}

THe Red-backed Shrike lays five or six eggs of a pinkwhite or cream-colour, with brown spots predominating at the larger end. Her nest is composed of wool, moss, bents of grass, alid hair, and is situated in furze-bushes, whitethorn hedges, \&c.

\section{THE CHOUGH.}

This bird builds her nest in sea-cliffs, in caves, old ruins, \&c., near the sea. It is composed of sticks, lined with a liberal application of wool and hair. Her eggs number five or six of a dirty white colour, spotted and blotched chiefly at the larger end with raw sienna-brown and ash colour.

\section{THE PUFFIN}

LAYs one grey-coloured egg marked with indistinct spots of pale brown; the nest is generally minus materials, so the egg is placed on the bare earth at the extremity of a burrow or fissure in a sea cliff. She often adopts a rabbit-burrow if 



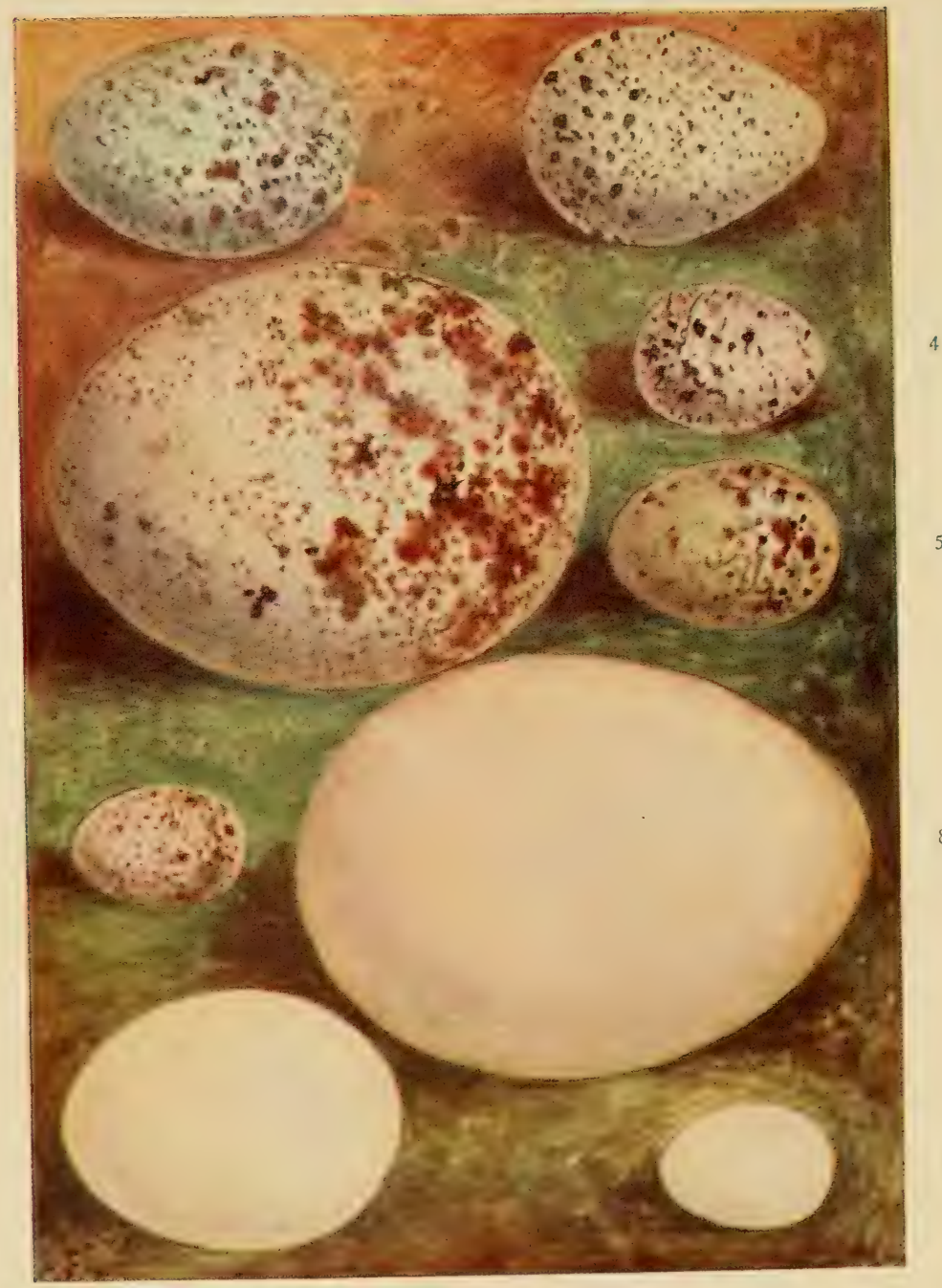

\section{EGGS.}

I. Ring Ouzel. 2. Kentish Plover. 3. Buzzard. 4. Cirl Bunting.

5. Hawfinch. 6. Stock Dove. 7. Dartford Warbler. 8. Pochard. 9. Black Redstart. 
it is situated in the immediate neighbourhood of the sea, and should the original owner or excavator be bold enough to dispute the right of proprietorship, this remarkable bird is not at all indisposed to do battle for possession of the situation her fancy has selected as a desirable place in which to carry out the duties imposed by Nature's law for the perpetuation of the species.

In the absence of a suitable cranny or rift in the rock, or the accommodation usually afforded by the presence of rabbits, the bird will set to work and excavate a hole sometimes as much as three feet deep, sticking to her task with such assiduity as often to endanger her safety from capture.

It seems, horvever, that she takes great care that whatever place is adopted for her nest it shall not be reached by even the highest tide. The nest of the Puffin is found in great numbers in the Isle of Wight, Puffin Island, Scilly Islands, Isle of Anglesea, and many islands on the coast of Scotland. The parent bird cannot be induced to leave her nest except by force, sitting very closely, and determinedly defending it with her singularly constructed and formidable beak, with which she bites most severely.

\section{THE RING OUZEL.}

The mountainous districts of the North of England and Scotland are the favourite nesting-places of this bird, which seems most at home in lonely secluded districts. It has often struck me that it is to this bird alone the mountain ash orves its existence high up in nearly every little mountain valley where no other tree is to be seen, the Ring Ouzel eating the berries and dropping the seed in all sorts of nut-of-the-way nooks and corners. 
The situation of the nest, its materials and structure, also the eggs of the Ring Ouzel and Blackbird, differ but little, and I have often had a difficulty in determining the rightful owner of a nest, until the parent bird has been watched on or off. The nest is composed of coarse grass, moss, and mud, with an inner lining of finer grass, and is generally situated in clefts of rock, steep banks, or old walls, sometimes quite on the ground. The eggs number four or five, of a dull bluish-green, freckled or blotched with reddish-brown, markings generally larger and fewer than those of the Blackbird.

\section{THE KENTISH PLOVER.}

No trouble is taken by this bird in nest-building, simply depositing its eggs in some depression or hollow of the sand or shingle on the southern coasts of England, principally Kent and Sussex. The eggrs number four, and are of a cream, stone, or pale testaceous-brown colour, streaked and spotted with black.

\section{THE BUZZARD.}

THe Buzzard sometimes builds a nest of sticks, hay, leaves, and wool; at other's adopts a crow's nest in some moderately high tree. Her eggs number two, three, and even four, and are of a dingy white; sometimes this colour alone, and at others spotted and blotched at the larger end with red-brown.

\section{THE CIRL BUNTING.}

Some low bush or furze is generally adopted by this bird for its nesting-place. The nest is composed of dry grass, roots, and moss, with generally an inner lining of hair, but 
sometimes without either moss or hair. The eggs number four or five, of a dull bluish or cinereous white with irregular streaks of dark brown, often terminating in a spot at one end.

\section{THE HAWFINCH.}

The Hawfinch builds in various kinds of trees and at various heights; sometimes its nest is found quite exposed in a whitethorn bush, or on the horizontal branch of an oak. It is built of twigs, \&c., intermixed with lichens, and interlined with fine fibrous roots and hair. IIer eggrs number from four to six, of a pale olive-green colour, irregularly streaked with dusky grey and spotted with black. The ground-colour is variable, being sometimes of a buffish hue.

\section{$\checkmark$ THE STOCK DOVE.}

ClefTS in rocks, rabbit-holes, cavities in the trunks of trecs, and often on the ground beneath thick furze-bushes which are next door to waterproof on account of their thickness, are the situations chosen by the Stock Dove. Very little trouble is taken with the nest, which merely consists of a few twigs and roots. The eggrs only number two, of a pure shining white.

\section{THE DARTFORD WARBLER.}

THick furze-bushes are the places chosen by this bird for its nusting-place on the commons of Kent and Surrey. The materials used are dead branches of furze, moss, and dry grass mixed with wool, and lined inside with finer dead grasses, the whole structure being loosely put together. The eggs number four or five, and are of a greenish, some- 
times buffish, white ground speckled all over with dark or olive brown and cinereous, which become more dense at the larger end and form a zone. The eggs are at times more numerously spotted than at others; then the markings are not so large.

\section{THE POCHARD.}

Tirrs bird breeds in the east and south of England, also in Scotland and Ireland, although it is much less numerous during the summer than the winter months. The position of its nest is similar to that of the Wild Duck, also the materials of which it is composed (dead grass and sedge, as well as down when the bird has begun to sit). Its eggs number from seven even to thirteen, but ten is the usual number laid, of a greenishbuff colour.

\section{THE BLACK REDSTART.}

Thrs well-known visitor breeds in many parts of Europe and North Africa, building a nest very similar to that of the Robin, composed chiefly of twigs, straw, dried grass, \&c., and situated in holes of walls and other positions similar to the above-mentioned bird. Five is the usual number of eggrs; however, four only, or as many as six, are found, generally pure white in colour, occasionally tinged faintly with brown. Cases are recorded where they have been found spotted at the larger end with minute brown spots.

\section{$\sqrt{\text { THE SPOTTED FLY-CATCHER. }}$}

MANY curious positions for rearing a family have been chosen by the Spotted Fly-catcher, but its nest is generally 



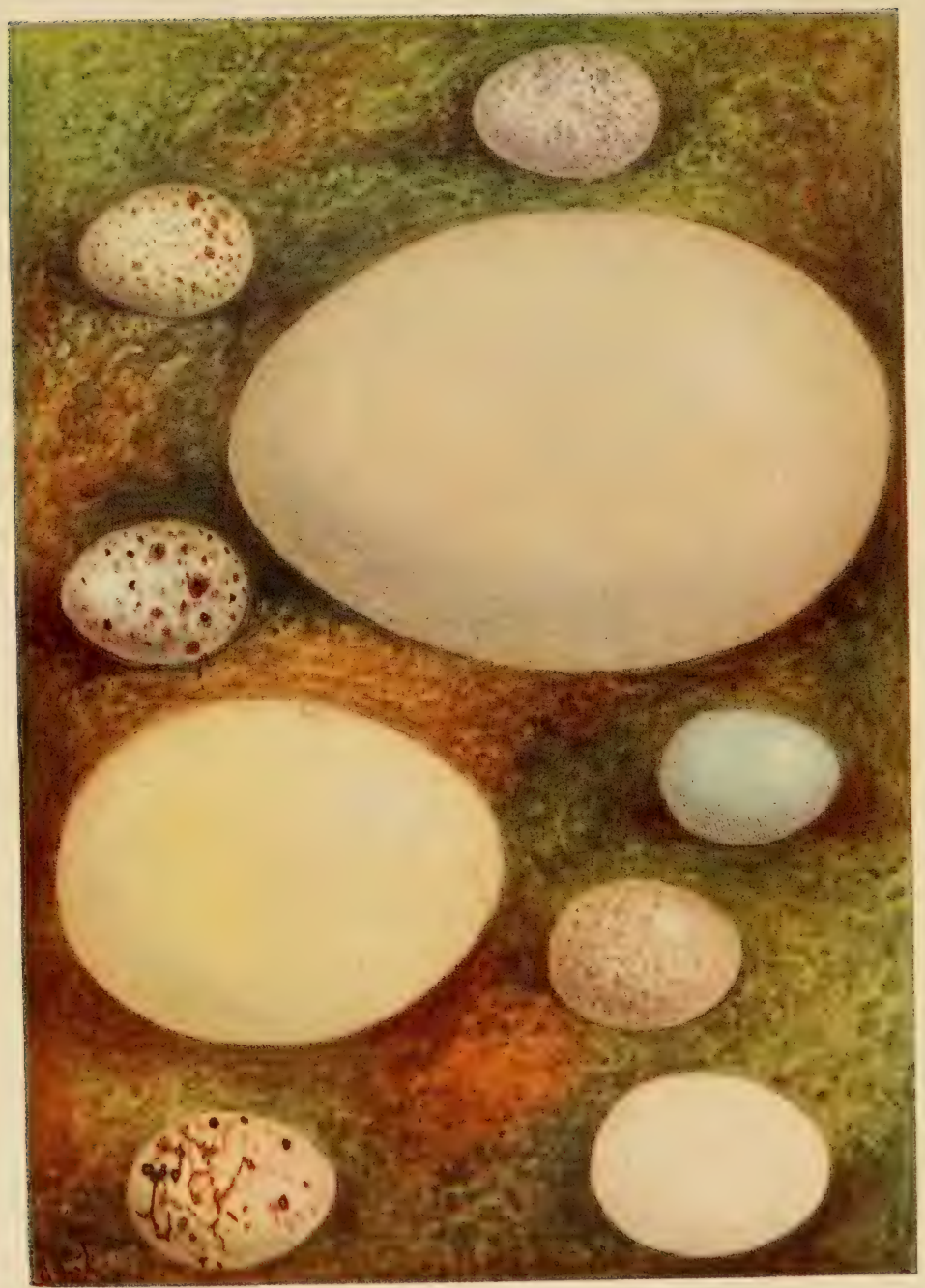

\section{EGGS.}

x. Spotted Fly-catcher. 2. Tree Sparrow. 3. Brambling. 4. Whinchat. 5. Scoter. 6. Grey Wagtail. 7. Smew. 8. Black-headed Bunting. 9. Great Spotted Woodpecker. 
found in trees which are trained against walls, barns, tool and summer houses. It is composed of a diversity of material, and no fixed rule seems to be adlered tobents, straws, moss new and old, hairs, feathers, \&c. The eggs number four, five, or even six, of a grey-white spotted with faint red; sometimes, but rarely, pale blue, unspotted. The ground-colour varies from grey or bluishwhite to pea-green, the markings also being in various shades, clouded, spotted, and blotched with faint red or reddish-brown.

THE TREE SPARROW.

HoLes in pollard and other trees are chosen as desirable situations by this bird for perpetuating its race, and sometimes in the thatches of old barns along with the Common House Sparrow. Its nest is very similar to that of its more widely-distributed and better-known kinsman, viz., of hay, dry grass, and straw, with a liberal lining of nice warm feathers. The eggrs generally number four or five, of a grey colour, thickly spotted with umber-brown or darker grey, sometimes white with grey spots or blotches, and may be described, like the Common Sparrow's, as variable.

\section{THE BRAMBLING.}

Scandinavia and other countries situated in high latitudes are the breeding-haunts of this little bird, which builds a nest very similar to the Chaffinch. It is placed fourteen or twenty feet from the ground, in the fork of a branch shooting out from the trunk of a birch or spruce fir-tree, and composed of moss, lichens, bark, mixed with thistledown, and lined with tine grass and feathers. Its egers 
number from five to seven, similar to those of the Chaffinch, the ground-colour being generally green, and the spots not so dark nor large.

\section{THE WHINCHAT.}

THE nest of this bird is composed of grass and moss of different kinds, the stronger on the outside, and the finer forming a lining for the interior, and is situated on the ground in positions where it is by no means an easy task for the most veteran collector to find it. It lays five or six eggs of a delicate bluish-green, rarely speckled or marked with red-brown.

\section{THE SCOTER.}

TIIE most northern counties of Scotland are the nestingplaces of this bird, which gathers together such materials as twigs, grasses, dry stalks, and leaves, placing them under cover, or in hiding, afforded by the low-growing shrubs or plants, and lining the whole with down. The eggs number from six to ten, and are of a pale greyishbuff colour, sometimes slightly tinged with green.

\section{THE GREY WAGTAIL.}

Sorre naturalists describe the position of this bird's nest as on the ground; but, personally, I have generally found them in the niches of rocks, or under overbanging ledges or banks. The nest is composed of moss, bents, grass, horsehair, often lined with a coat of cow's-hair, which they rub off against walls and trees in the spring-time. This bird's eggs number five or six, and are of a grey colour, mottled and spotted with ochre-grey or brown, variable. 



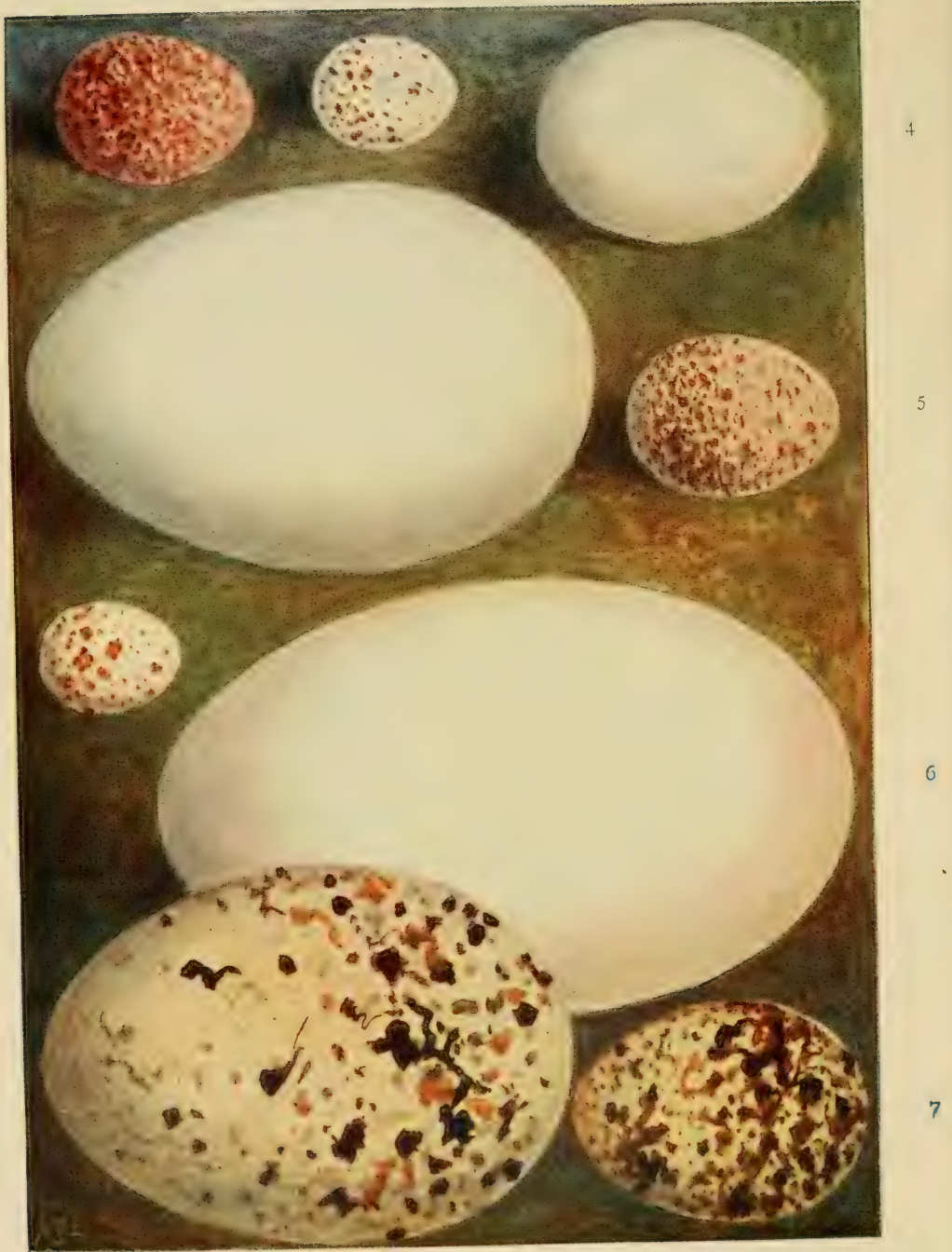

EGGS.

I. Rock Pipit. 2. Cormorant. 3. Creeper. 4. Turtle Dove.

5. Shore Lark. 6. Gannet. 7. Quail. 8. Oyster-catcher. 9. Cole Tit. 


\section{THE SIIEW.}

THe nesting-place of this bird is in high latitudes, such as north-east Russia, and the situation chosen is in the hollow trunk of a tree. The material of which the nest is composed is taken from the bird's body, and consists entirely of down. Her eggs number from seven to eight, very similar to those of the Wigeon, creamy-white in colour, fine-grained, and rather glossy.

\section{$\int$ THE BLACK-HEADED BUNTING.}

Morst swampy localities are chosen by this bird as the situation for its nest, which is composed of dried grass, moss, and an inner lining of finer grass, reed-down, or horsehair, and generally, though not always, placed on the ground, among rushes or coarse long grass. It lays four or five eggrs of a pale reddish-brown or grey with a rosy tinge, streaked, veined, and spotted with brown of a rich dark purple shade.

\section{THE GREAT SPOTTED WOODPECKER.}

Trre position of the Woodpecker's nest is in the hollow trunk of some tree. A hole generally about two feet deep is chosen, but the parent bird does not seem to consider any attempt at nest-building in any way necessary. The egg's are laid on pieces of wood chipped off inside, and number four or five, white, occasionally stained or dyed by the material on which they are laid.

THE ROCK PIPIT.

LEDGES or crevices of rocks near the sea-shore are the favourite building-places of this bird. It collects such 
yellowish-brown, mottled and clouded or blotched with red or olive brown; variable both in ground-colour and markings.

THE OYSTER-CATCHER.

ThIs bird lays its eggs, which number three or four-three being the general rule-on the bare ground, mostly in slight declivities, taking care that they are above highwater-mark. Sometimes a few bents, pebbles, or broken shells are used as a sort of lining. The eggs are stone or cream colour, of a variety of shades, blotched with dark brown, occasionally streaked and spotted with a lighter hue. The markings are variable in character and position, some being pretty equally distributed over the eggs, whilst others are inclined to form a belt round the larger end.

\section{THE COLE TIT.}

Trunks of trees, holes in walls and banks made by rats, moles, or mice, are selected for incubation purposes by this little bird. The nest is built of moss, wool, and hair, and contains from five to eight, or even nine eggs, white, spotted and freckled with light red or red-brown.

\section{THE GUILLENOT.}

Tre Guillemot makes no nest at all, but deposits its single egg on the ledges of sea-cliffs in a great many places round our coasts. A verbal description of it is almost useless, as the colouring presents such a wonderful variety of tints. The ground-colours are white, cream, yellowishgreen, blue, reddish-brown, pea-green, purplish-brown, \&c. Some are profusely spotted and blotched or streaked with black, black-brown, or grey in great variety; whilst others 



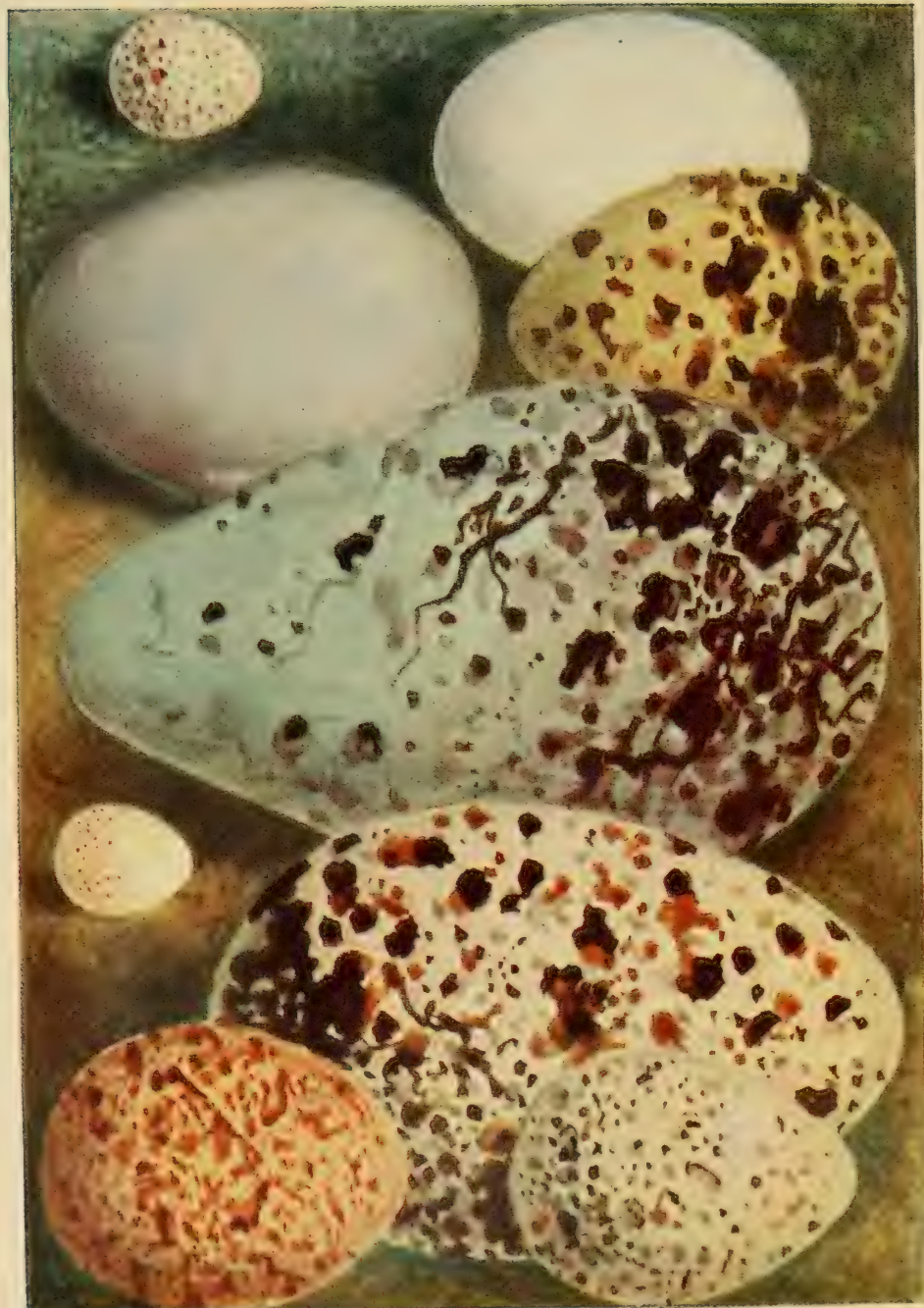

EGGS.

I. Guillemot. 2. Rock Dove. 3. Dotterel. 4. Marsh Tit. 5. Little Auk.

6. Red-Legged Partridge. 7. Sanderling. 8. Long-tailed Titmouse. 9. Razor-bill. 
are scarcely marked at all. Our illustration may be taken as a very good specimen of one lind of colouring and marking, though a very pretty one might be given of an entirely different colour and character.

THE ROCK DOVE.

LEDGES and fissures or crevices in sea-cliffs are the restingplaces of this bird, which uses sticks, twig's, heath, and dead grass for building purposes. Her eggs are two in number, quite white.

THE DOTTEREI،.

Mountain-tops in the North of Scotland are the favourite nesting-places of the Dotterel, which is now becoming comparatively rare in districts where it was once common. It uses no materials for nest-making, simply laying three egg's in a slight cavity amongst woolly-fringe moss or other mountain vegetation which affords some little concealment. The eggs are of a dark cream or olivaccous-brown colour thickly blotched or spotted with dark brown or brownishblack.

THE MARSH TIT.

Hotes in trees (generally willows or pollards), banks, \&e., are the places adopted by the Marsh Tit for its nest, which is composed of moss, wool, and down from rabbits, or the ripe catkins of willorws. Her eggs number from six to eight, or even as many as ten have been found. They are white, spotted with red-brown, more thickly at the larger end.

THE LITTLE AUK.

THE rocky shores of Spitzbergen, Greenland, and Iceland form suitable breeding resorts for this bird, which makes no 
nest, but deposits its single egg on the bare ground in some crevice or under loose rocks. The egg is of a pale greenish-blue, or white tinged with greenish-blue, a little spotted and veined, especially at the larger end, with rustcolour or yellowish-brown. Sometimes the egg has no spots or streaks, at others only indistinctly streaked or veined at the large end.

\section{THE RED-LEGGED PARTRIDGE.}

TuIs bird makes a slight nest of bents and leaves upon the ground in grass, corn, or clover fields; however, instances have been cited where it has been found at considerable elevation. But this departure from the general rule I have noticed with other birds on rare occasions. Her eggs number from twelve to eighteen, of a yellow-grey or cream colour, marked with red or cinnamon-brown.

\section{THE SANDERLING.}

Trie Sanderling is only a visitor to our shores, and breeds in Arctic countries, such as Labrador, Greenland, \&c. Its nest is composed of grass and built upon the ground. The eggs are four in number, of a buffish-olive ground-colour, spotted and mottled plentifully with dark brown or black, also with indistinct sub-markings of a greyish tinge.

\section{THE LONG-TAILED TIT.}

HuDGES and bushes are the positions taken up by this skilled little architect and builder, whose beautiful work wins the admiration of all naturalists. Oval in shape, it is of large size compared with the bird, and strongly and compactly put together with wool, lichens, and moss, the two former of which adhere very closely when they once become 
entangled. A small ho'e is left on one side, pretty high up. for ingress and egress, and the inside is lined with feathers, which make it as warm and comfortable, at least, to the buman understanding, as the outside is compact. The eggs number from seven to ten, and even sixteen or twenty, which are probably the production of more than one bird; white or rosy-white until blown (by reason of the yolk showing through the thin transparent shell), with very small reddish-brown spots round the larger end.

\section{THE RAZOR-BILL.}

Tıe Guillemot and Razor-Bill appear to be very much alike in the choice of their position for breeding purposes, and alike only lay one egg each; but that of the latter differs very much from the former in diversity of colouring. It is white or buffy-white, spotted and blotehed with black, chestnut, or reddish-brown.

\section{THE SANDWICH TERN.}

Low, sandy islands, such as the Wamses at the Farne and Scilly Isles, and at suitable places on the Scottish and Irish coasts, are the favourite breeding places of this Tern. Sometimes a slight hollow is scratched in the sand or gravel; at others no declivity at all is formed for the nest. Occasionally a few bits of grass are used as a lining. The eggs number two or three, and vary from creamy-white to dark buff in ground colour. They are blotehed and spotted with reddish-and blackish-iorown and underlying light grey markings. 


\section{THE ARCTIC TERN.}

BreEds on low islands and in suitable places along the enast, chiefly in the northern parts of our kingdom. I have found most nests amongst the shingle. As a rule, no materials whatever are used. The eggs are two or three, varying from greyish-buff to buffish-brown (I have seen them occasionally pale blue), spotted and blotched with blackish-brown and underlying pale grey. The eggs of this bird run slightly smaller than those of the Common Tern.

\section{THE COMMON TERN.}

The situation, nest, and eggs of this bird differ but little from those of the Arctic Tern, except that the nest is often farther away from the water's edge, and generally lined with bits of withered grass and weed. The bird is a more abundant breeder, however, round the English coast, and less numerous in Scotland. Its eggs run slightly larger, are not so boldly marked, and the ground colour is less prone to an olive tinge.

\section{THE LESSER TERN.}

ONE result of the recently-passed law for the better protection of Wild Birds ought to be the stoppage of the decrease of this beautiful little Tern's numbers. It breeds in suitable localities round our coast, depositing its eggs on the shingle without making any nest at all. These number two, three, and occasionally four, similar in coloration to those of the Common and Arctic Terns, but smaller in size. 



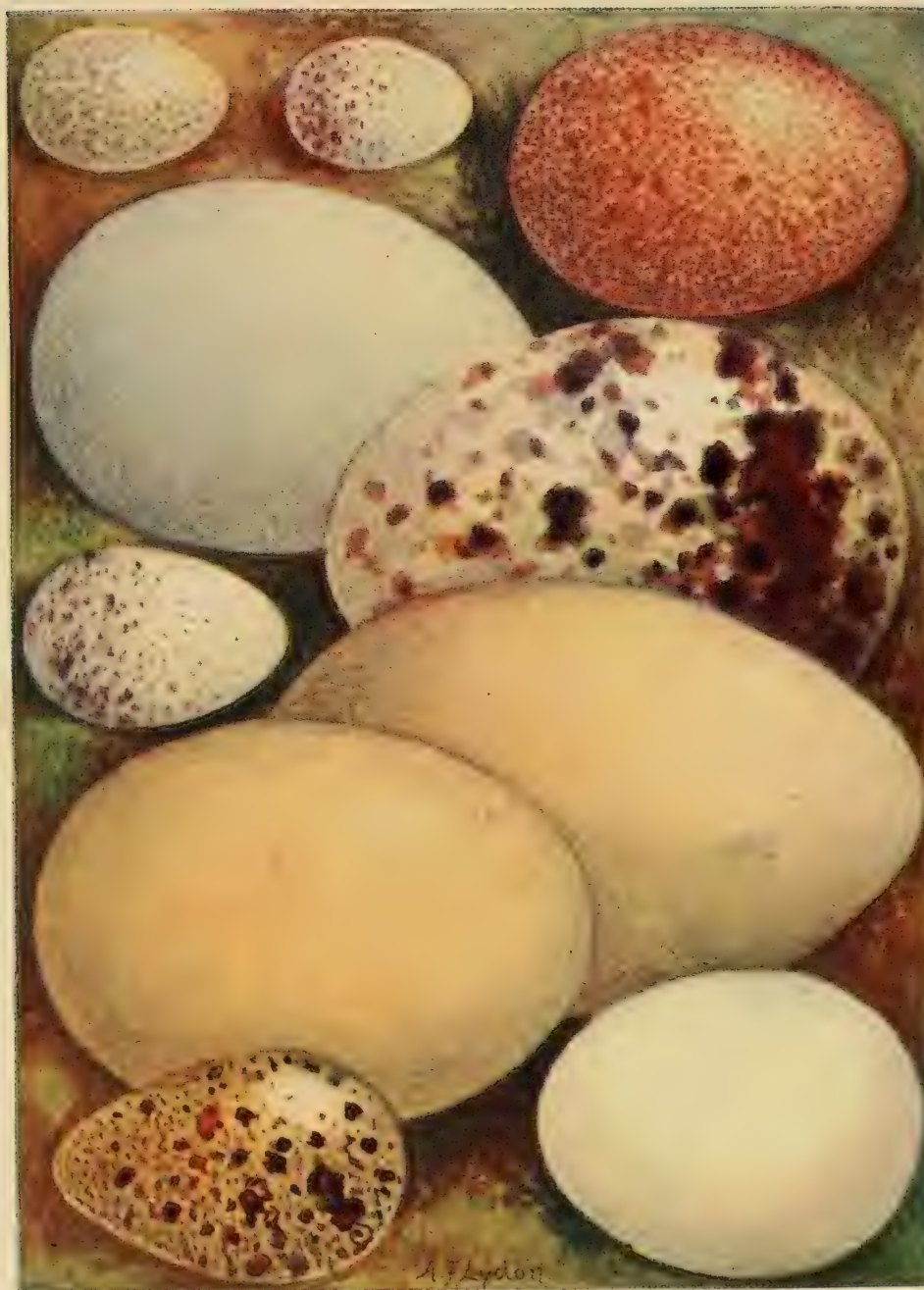

EGGS.
r. Yellow Wagtail
? Twite.
3. Hobb;
4. Marsh Harrier.
5. Osprey.
6. Snow Bunting
7. Tufted Duck. 8. Goosander
9 Ringed Pluver. 
THE GOSHAWK.

IIrgir trees on the outsides of forests and large woods are chosen by the Goshawk for the accommodation of its nest, which is made of sticks, twigs, rootlets, and noss. It lays four egres generally, but sometimes only three are found, and at others as many as five; of a pale bluish-white, occasionally marked with small, light reddish-brown spots. The bird has, horvever, long since ceased to breed in the British Isles, unless as a rare exception.

\section{THE YELLOW IVAGTAIL.}

I HAVE met with this somewhat local though common summer visitor's nest most abundantly in the Yorkshire dales. It is situated on the ground, in meadows, pastures, and on commons, and is generally sheltered by a clod, piece of overhanging bank, or tuft of grass, and is often most difficult to find. It is composed of grass, moss, and rootlets, with an inner lining of horse and cow hair, sometimes a few feathers. The eggs number from four to six, greyish-white in ground colour, and thickly speckled with greyish- and yellowish-brown. They are very similar to those of the Grey Wagtail.

\section{THE GREY LAG GOOSE.}

Tins bird places its nest on the ground in desolate swamps and on lonely moors in the Highlands of Scotland, and the islands lying to the west; also in Ireland, in County Monaghan. It builds a large nest of sticks, heather, twigs, reed, grass, and moss, with an inner lining of down from 
the bird's own body. The eggs number six to cight, or even a dozen, creamy-white, unpolished.

\section{THE MUTE SWAN.}

Althodgh semi-domesticated and holding its footing only by the help of strict protection, the Swan has been so long with us that it merits treatment, I think. Its nest is composed of reeds, rushes, and grass, with a slight lining of down and feathers, and is placed on small islands and on the banks of lakes and rivers. The eggs number from three or four to a dozen, according to the age of the parent bird, and are greenish-white, roughish, and unspotted.

\section{THE SHAG.}

In caves, fissures, on ledges of maritime cliffs, and amongst huge boulders piled up along the beach of small rocky islands around our coasts, may be found the nest of this bird. I have seen specimens close together vary considerably in size according to the accommodation. It is composed of seaweed, sticks, sprigs of heather, turf, and grass. The eggs number two, three, four, or five, generally one of the first two numbers, the real shell being of a delicate bluish-green, but difficult to see on account of the thick, chalky encrustation.

\section{THE CRESTED TIT.}

TIIE nest of this pretty little bird is placed in a hole in the branch or trunk of a tree at varying heights from the 
ground, and is met with only in the pine forests of Scotland. It is composed of grass, moss, nool, fur, and feather's. The eggs number four to seven or eight, and are white in ground colour, freckled and spotted with reddish-brown, generally forming a belt round the large end.

\section{THE GADIVALL.}

This bird is only known to nest in one or tivo places in Norfolk. It has been my pleas'rie to examine two nestsone situated amongst rough, dead grass, and the other in a tuft of rushes-in each case quite close to the water. The nest is made of dry grass, rushes, or withered leaves, and lined with beautiful soft down. From eight to twelve or thirteen creamy-white eggs are laid.

\section{THE TUFTED DUCR.}

This member of the Duck family selects the neatest and best concealed situation of all. It is gencrally well hidden in a tussock of rushes growing in or close to the water of a mere or pond. T'he nest is made of dead rushes, grass, or reeds, and is lined with small dark pieces of down, with whitish centres. The eggrs are light greenishbuff in colour, and number from eight to ten, or even thirteen. They are very similar to those of the Pochard, but the down tufts in the nest are darker.

\section{THE STONE CURLEW.}

Found on stony, arable land, commons, and rough, bare pastures. I have watehed the bird through my binoculars, 
when put off her eggs, fly to some distance and remain quite flat upon the ground, with which she closely harmonises. The nest is a mere unlined hollow, with sometimes a few bents in it, which may as easily as not have been blown there. Her eggs number two, of light buffish to clay-brown ground colour, blotched and spotted with blackish-brown and grey. I have noticed that one egg in a nest will differ radically in the size and intensity of its markings from the others.

\section{THE FULMAR PETREL.}

So far as the British Isles are concerned, it is perhaps only safe to say that this bird breeds at St. Kilda, although it has been reported from other quarters. Its nest is situated on ledges of cliffs covered with a sufficient amount of earth for the bird to make a burrow in, or in crevices. It is sometimes lined with a scanty supply of dry grass; at others no lining at all is used. The bird lays a single rough, chalky-white egg.

\section{THE GARGANEY.}

Norfolk seems to be the last breeding resort of this duck. Its nest is situated in reed beds, or such other vegetation as will afford the bird plenty of concealment. It is composed of reeds, leaves, or dry grass, and is lined with pieces of down, the long white tips of which distinguish it from the Teal. The eggs are creany-white, like those of 
the bird above-named, and number from seven or erght ta as many as thirteen.

THE GOOSANDER.

The Goosander breeds in the Highlands of Scotlind, and situates its nest in hollow trees and crevices of rock, generally near the water. Very little, if any, material is said to be used excepting the warm lining of greyishwhite down from the bird's own body. The eggs number from eight to a dozen or thirteen, creamy-white and smoothshelled.

\section{$\sqrt{\text { THE GREAT CRESTED GREBE. }}$}

TIIE midland and eastern counties contain the favourite breeding resorts of this handsome bird. Its nest is composed of all kinds of dead aquatic vegetation, such as reeds and flags, and is situated in or on the water of lakes, broads, large tarns, and meres. The bird lays three or four eggs, sometimes even as many as five, white and chalky when first laid, but soon becoming soiled and dirty.

\section{THE BLACK GUILLEITOT.}

The Isle of Man, Hebrides, Orkneys, Shetlands, and some parts of Ireland are favoured by this bird as a breecler. Its nest is situated in crevices and under ledges and boulders of rock. No materials of any lind are used for its nest. The eggs number two, varying from light bluish-green to light buffy-white in ground colour, spotted, 
speckled, and blotched with rich blackish-brown and pale reddish-brown and underlying grey markings.

\section{THE RITTIWAKE.}

Trre nest of the Kittivake is situated on ledges of maritime cliffs round our coast, and at the Farne Islands I have seen the bird occupying such a small corner that it was unable to sit properly on its egrgs. The nest is made of seaweed and lined with dead grass. Its eggs number trwo, three, and rarely four, and vary from light greenishblue to stone colour, or buffish-brown, blotched and spotted with varying shades of brown and grey. The markings sometimes form a zone round the larger end.

\section{THE SHORT.EARED OWL.}

ON the ground, amongst heather or sedges, this bird makes its nest, in the eastern and northern counties and in Scotland. It uses next to no materials, but such as are present consist of bits of dead reeds and leaves. Its eggs number from four to seven or eight, pure white, unspotted, and oval in shape.

\section{THE LESSER SPOTTED IVOODPECKER.}

Almovgh nowhere abundant, this bird breedss in suitable districts throughout England. Its nest is situated in a hole in the trunk or some large branch of a tree, and is 
about seren to a dozen inches deep. I have found it quite close to London. No materials are used for the nest except chippings of dry wood detached in the construction of the hole. Eggs from five or six to eight, and even nine, white, without spots, and polished.

\section{$\checkmark$ THE WILLOW WREN.}

The nest of the Willow Wren, or Willow Warbler, is situated on or near the ground in fields, orchards, woods, and almost everywhere. It is made of moss, bits of dried grass, occasionally fern-fronds or leaves, and is lined with feathers and hair. The eggs number from four or five to seven, and upon occasion I have found eight. They are white, spotted with reddish-brown.

\section{$\sqrt{\text { THE SEDGE }}$ W'ARBLER.}

I HAVE found this bird's nest amongst low bushes, tufts of tall, coarse grass, and amongst nettles; generally, though not always, near water. It is composed of grass-stems lined with finer grass, horsebair, and sometimes vegetable down in small quantities. The eggs number five or six, light yellowish-brown tinged with blue, which is rarely seen on account of the closely-crowded yellowish-brown or buffish-brown markings. The eggs generally have a few streaks or lines of blackish-brown on the larger end.

\section{THE RED-BREASTED MERGANSER.}

Trie nest of this bird is found on the ground, concealed beneath rocks, or amongst the vegetation growing on the 
banks of large bodies of water in Scotland and Ireland. I have seen it on the banks of streams, where it must have been washed away by the first freshet. It is composed of bits of heather, dry leaves, and down from the bird's own body. The eggs number from six or seven to nine, or even a dozen, and vary from buffish-grey to pale olive-grey in colour.

\section{THE GREENSHANK.}

Breeds chiefly in the Highlands of Scotland, and the islands lying to the west thereof. Its nest is merely a slight declivity lined with a few bits of dry grass, dead heather, or leaves. The egrgs number four, of a stone colour or creamy-white, spotted and blotehed dark reddish-brown and grey.

\section{THE WHIMIBREL.}

Tire islands to the west and north of Scotland are the breeding home of the Whimbrel. A slight dry hollow in the shelter of a tussock of grass or heath is selected on some lonely piece of moor. The nest is lined with a few blades of withered grass, sprigs of heather, or dead leaves. The eggs number four, varying from darkish buff to olivegreen, spotted and blotched with reddish-brown, olivelurown, and underlying markings of grey.

\section{$\sqrt{\text { THE REED WARBLER. }}$}

T'rrs bird suspends its nest between the stems of reeds and hranches of willows and other trees growing from or over 



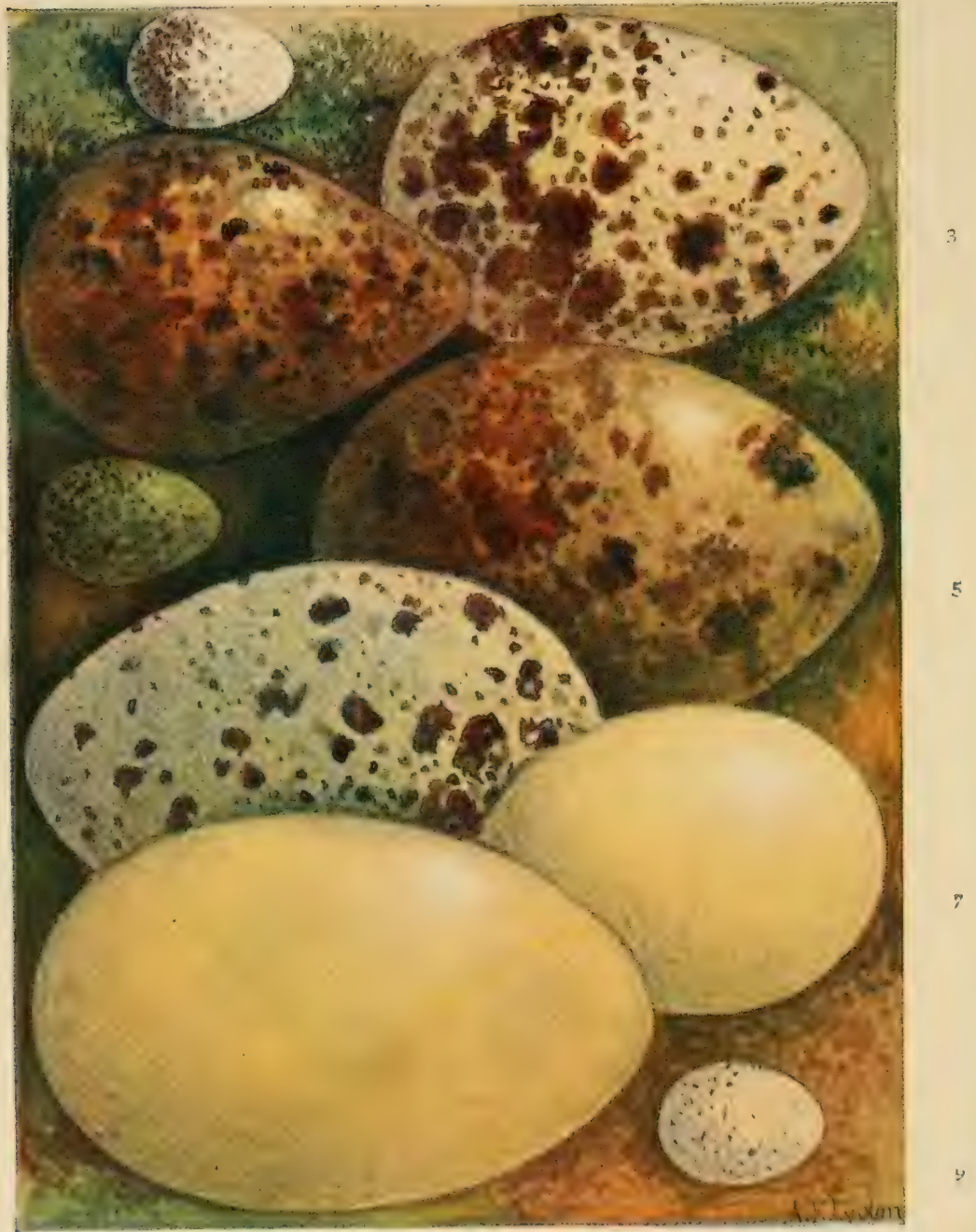

EGGS

r. Wood Warbler 2 Greenshank 3. Sandwich Tern.
;. Reed Warbler
5 Whimbrel.
6. Black (iullemot.
Garganey.

B Red-breasted Merganser a Pearcled Tit. 
water. It is composed of sedge grass, reed leaves, moss, hair, and reed down. It is found in the Southern and Eastern portions of England. The eggs number four or five, light greenish-blue or greenish-Ivhite, spotted, freckled, and clouded with greenish-brown or dark olive, and underlying markings of greyish-brown. The spots are generally most numerous round the larger end of the egg.

\section{THE WOOD WARBLER.}

BreEds sparingly throughout England and in Southern Scotland. Its nest is placed in tufts of coarse grass and other vegetation on the ground, and is composed of dry grass, leaves, and bits of moss, and lined with horsehair only. This feature will readily distinguish it from the nest of the Chiffchaff and Willow Wren, whose semi-domed structures it closely resembles in other respects. The eggs number from five to seven, white in ground colour, numerously spotted and freckled with purplish-brown and underlying markings of grey.

\section{THE TWITE.}

The Twite breeds on the moors in the North of England, Scotland, and in Ireland. Its nest is situated on or near the ground amongst heather or furze. It is composed of sprigs of heath, and lined with rootlets, wool, feathers, and hair. The eggrs number four or five, sometimes six, and are similar to those of the Linnet, pale bluish-green, spotted, speckled, and streaked with purplish-red and reddish- 
brown. I have found several nests close together on a small rocky islet in the Highlands.

\section{THE BEARDED TIT.}

Ir is thought by some writers that the exceptionally hard weather we experienced last winter (1894-5) has extinguished this little bird in its last resort, the fens of Norfolk and Cambridgeshire; however, it is to be hoped that this is not the case. Its nest is composed of dead sedge and reed leaves, lined with grass and reed down, and is situated near the ground in some large reed bed. The eggs number from four to seven, light brownisl_white, sparingly marked with streaks and spots of dark brown.

THE ROSEATE TERN.

So rare a breeder with us has this bird become, that a celebrated authority recently included it in a work on British Birds' Nests only after some hesitation ; but I am pleased to say that two pairs bred last year in one of their old haunts well known to me. The nest is simply a hollow in the sand or shingle of a small rocky island, at no great height from the sea. The eggs number two or three, and exactly resemble in coloration and size those of the Common and Arctic Terns.

\section{THE RINGED PLOVER.}

Triss pretty little bird makes no nest in the proper sense of the word, althongh I have found a few pebbles and 



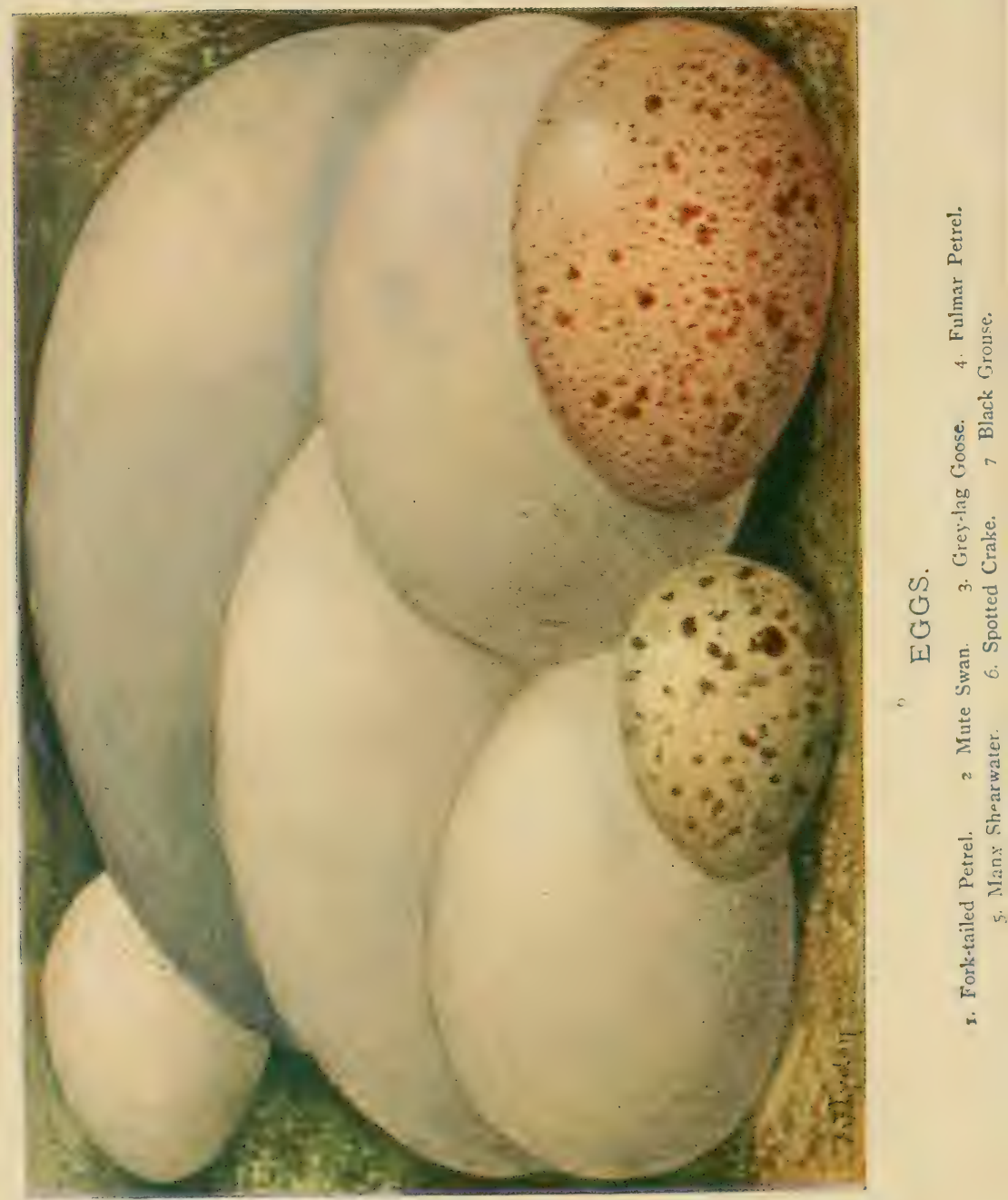


small shells used when a rocky place instead of a sandy beach has been chosen for breeding upon. Its nest is generally well above high-water mark, amongst fine sand, shingle, or on bare rock round our coast, and on the shores of inland sheets of water. The eggs number four, and vary from pale buff to stone or cream colour, spotted anci speckled all over with small brownish-black and underlying inky-grey marks.

\section{THE MANX SHEARIVATER.}

Tue Manx Shearwater brecds on the western coasts of England and Scotland, in the Hebrides and islands to the north of Scotland; also in several parts of the Irish coast and the off-lying islands. Its nest is situated at the end of a deep burrow, which is generally dug by the bird itself. Some observers have reported it to consist of bits of grass and stalks, and others have found no attempt at all at nest-building in some of the burrorvs they have opened. It lays a single white, smooth egg.

\section{THE PINTAIL DUCK.}

Turs uncommon Duck breeds in one or two parts of Ireland and Scotland still, it is said on good authority. Its nest consists of rushes, sedge, dead grass, and tufts of dark brown down bearing white tips, and is placed amongst rushes and such other coarse vegetation as will afford the bird shelter. The eggs number from six to cight, or even ten, of a pale buff colour tinged with green. 


\section{LEACH'S FORK-TAILED PETREL.}

The St. Kilda group of islands forms the principal British breeding haunt of this bird, although colonies nest in the Hebrides and on the Blaskets off the Irish coast. The nest is situated at the end of a burrow made by the bird itself, or under rocks, and is composed of withered grass, moss, and lichens. Only one egg is laid, white in ground colour, with a belt of small brownish-red spots round the larger end.

\section{THE RED-NECKED PHALAROPE.}

A Litrue withered grass or other herbage is used to line the depression selected by this bird for its nesting place, which is situated on the ground in grassy swamps and marshes, near water as a rule, in the North of Scotland and some of the islands lying to the west and north thereof. Four eggs are laid, varying in ground colour from olive to pale buff, spotted, speckled, and blotched with varying shades of dark brown and underlying specks of light grey.

\section{THE HOOPOE.}

Although this bird has bred in different parts of England, its chances of doing so now are somerwhat remote, on account of the merciless persecution it suffers at the hands of gunner's. Its nest is situated in holes in trees, walls, or rocks, and is composed of bits of straws and dry grass. The eggs number from five to seven, and vary from light greenish-blue to pale buff, with minute pitmarks over their surface. 



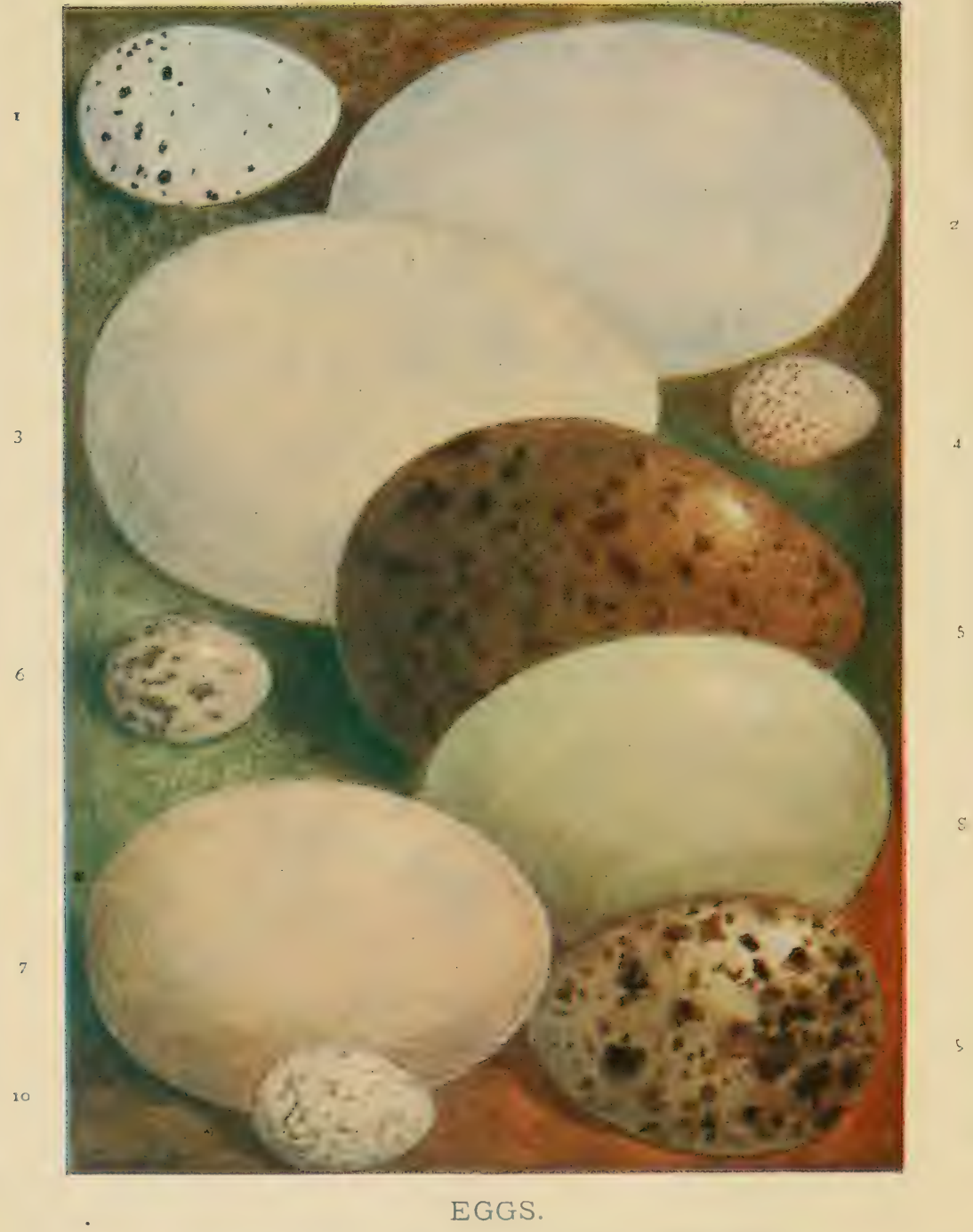

r. Golden Oriole. 2. Shag. 3. Gadwall. 4. Willow TVren.
5. Richardson's Skua.
6. Marsh Warbler.
7. Goshawk.
8. Pintail.

o. Arctic Tern. то. Blue-headed Wagtail. 


\section{THE GOLDEN ORIOLE.}

Tris bird is, to a very great extent, an accidental visitor to our shores, but it is thought by eminent authorities that it would become a common breeder with us were it not so dear to the heart of the collector. It has bred in several of the southern counties of England, and suspends its nest, which is composed of strips of bark, wool, selge, grass, and leaves, with an inner lining of flower-heads of grass, beneath the forks of a large horizontal branch at some considerable height from the ground. The eggs number four to five or six, are white or light creamy-white, spotted with purplish-brown and underlying markings of grey.

\section{THE OSPREY.}

Tue Osprey, now only met with in one or two remote parts of Scotland, emp!oys sticks, turf, moss, and wool in the construction of its bulky nest, which it builds on the top of a tall tree or ruin. The eggs number three, sometimes four, varying from white to creamy-white in ground colour, beautifully marked, and especially so at the larger end, as a rule with rich reddish-brown. The markings vary considerably.

\section{THE WHITE WAGTAIL.}

Altuovan this bird is the Continental representative of our Pied Waggtail, there are on record many well-authenticated instances of its breeding in this country. It difter's from the Pied Wagtail in being bluish or slate grey, where 
that bird is black, below the nape. Its nest, and the situation in which it is placed, do not differ from that of the bird just named. The eggs are also similar, but are said to be subject to greater variation in colour and markings.

\section{THE BLUE-HEADED WAGTAIL.}

Tire nest of this somewhat rare visitor has several times been found in Northumberland, and it has in all probability nested on many occasions elsewhere, without its identity being clearly established. The nest is made of dry grass, fine roots, and moss, lined with hair and occasionally a few feathers, and is situated on a bank or amongst grass or corn in a similar position to that of the Yellow Wagtail. T'he eggs number five as a rule, but six are sometimes found, of a yellowish-white ground colour, spotted, freckled, and clouded with light brown, and occasionally streaked on the larger end with fine blackish-brown lines.

\section{MONTAGU'S HARRIER.}

Altirougir this bird rarely breeds with us now, its nest has occasionally been met with in recent years in the southern counties. The nest is placed on the ground amongst heath, fern, furze, or growing crops, and consists of a few twigs, straws, and bits of dead grass. Its eggs number from four to six, of a faint bluish-white, and are on rare occasions marked with a few light reddish-brown spots. 



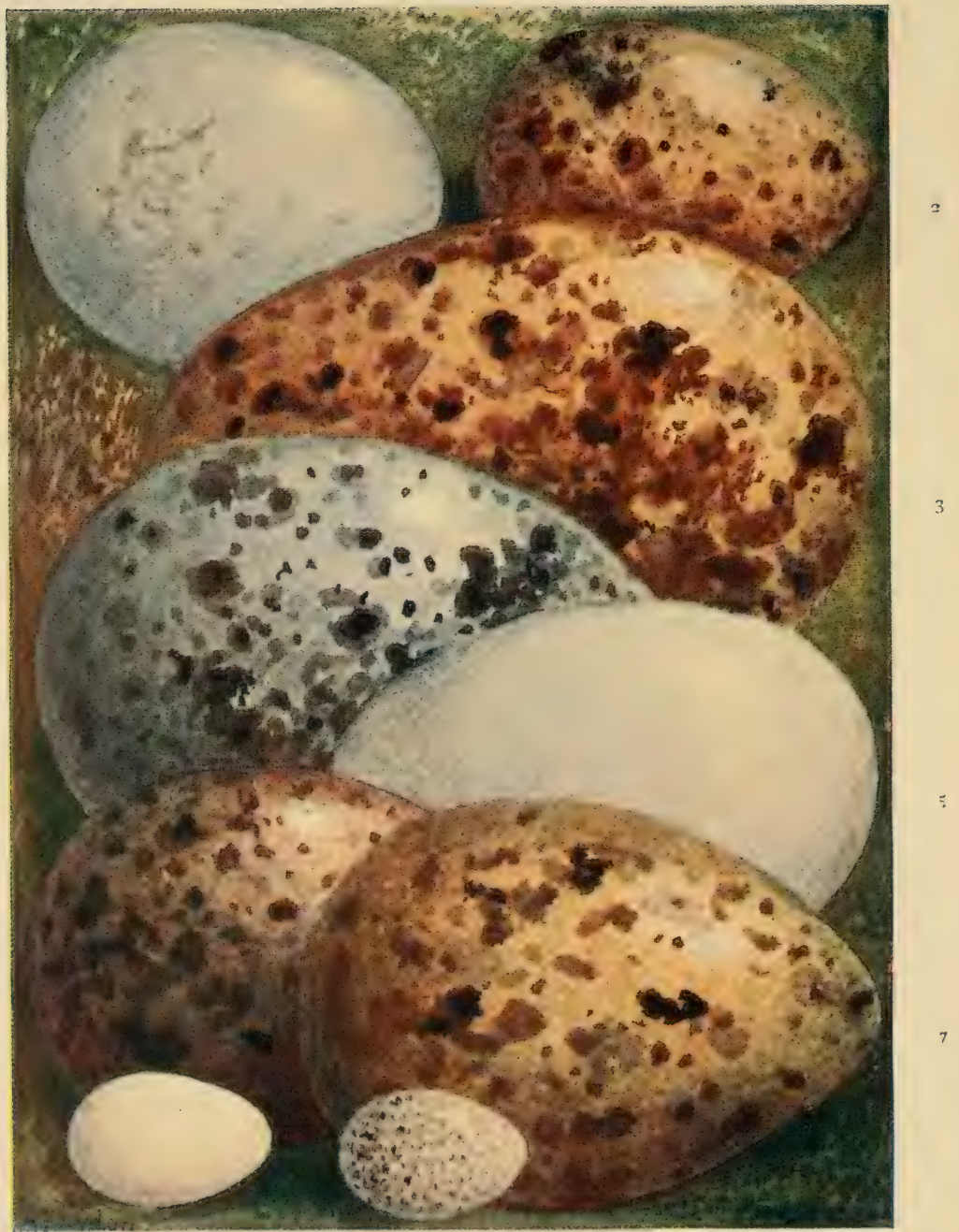

EGGS.

t. Hen Harrier. 2 Roseate Tern. 3 Great Black-backed Ciull. 4 Lesser Black-backed Gull. 5. Great Crested Grebe. 6 Kittiwake. 7. Stone Curlew. 8 Lesser Spotted Woodpecker. o White Wagtail. 


\section{THE HEN HARRIER.}

GAME-preserving has proved a disastrous business to this bird, and it now only breeds in a few of its old strongholds, such as Cornwall, Wales, the Highlands, Orkneys, and Hebrides, where I have met with it. Its nest is composed of sticks, sprigs of heather, dry grass, and wool, and is placed upon the ground in deep heather. The eggs number from four to six, of a pale bluish-white colour, rarcly marked with a few reddish-brown spots.

\section{THE MARSH HARRIER.}

STICKS, reeds, and sedge are the materials used by this bird for building its nest, which is situated on the ground, although instances have been reported of it occurring in a tree. It is said to still breed in Norfolk and the West of England. The eggs number three or four, sometimes as many as six, it is said. They are greyish-white, slightly tinged with light bluish-green, and occasionally marked with rusty brown.

\section{THE HOBBY.}

This bird still breeds in very small numbers in the Midlands and in the Eastern Counties. It selects the old nest of a Crow, Wood Pigeon, or Magpie, and deposits its three or four egrgs in it without any attempt at nest-building. The eggs are yellowish-white in ground colour, hut this is almost entirely hidden by the thick marking of reddishbrown. 
RICHARDSON'S SKUA.

THE islands lying to the West and North of Scotland, also parts of the far north of the mainland, are chosen by this Skua for its brceding quarters. The nest is simply a slight hollow, sparingly lined with a fer bits of withered grass, and is situated on wild, unfrequented moors and bog-land. The eggs number two, but upon occasion one only is found, and sometimes as many as three. They vary from olive-green to reddish-brown in ground colour, spotted and blotehed with blackish-brown and light grey. I have seen them harmonise so closely with their surroundings that I had a great difficulty in finding them, though I had marked the whereabouts of the nest within a few feet through my binoculars.

\section{THE LESSER BLACK-BACKED GULL.}

Low rocky islands are the favourite brecding places of this Gull, and they are now particularly numerous at the Farne Islands, where I have seen the eggs lying about so thickly that the visitor had to exercise great care to avoid treading upon them. Sometimes quite a large quantity of seaweed is used in making the nest, at others a few bits of grass and roots, and in some cases, where bare peat earth is available, simply a hollow is scratched out. The eggs as a rule number three, but sometimes only two are met with. I have seen it stated that the bird oceasionally lays four, but out of the hundreds of nests I have examined I have never had the luck to see that number. In coloration they vary from pale greyish-green to reddishbrown, blotched and spotted with blackish- and greyish- 
brown. Sometimes the markings take the form of streaks. The eggs, although as a rule darker than those of the Herring Gull, are very difficult to distinguish, and I have found no safe method short of watching the parent birds on the nest.

\section{THE GREAT BLACK-BACKED GULL}

THE flat-topped summits of rocks, stacks, and high maritime cliffs are the usual situation for this Gull's nest; horvever, I have met with it on comparatively lorv rocky islets in Highland sea-lochs. It does not breed on the East Coast of England. Its nest is made of bits of heather, dead grass, seawced, and sometimes a few feathers, and varies in size. The eggs number three, but sometimes only two are found, greyish-brown or stone colour, tinged with olive and spotted with blackish-brown and dark grey.

\section{THE BLACK GROUSE.}

Turs bird places its nest amongst deep heather, long grass, and rushes, ferns, and brambles, in suitable moorland parts of England, Wales, and Scotland. It is simply a hollow lined with a fer bits of fern, heath, or dead grass. The eggrs number six to ten, or even more, yellowish-white to buff, spotted with rich reddish-brown. I have generally found it through putting the hen off her nest.

\section{THE MIARSH WARBLER.}

A situation such as that afforded by a stunted bush orergrown with weeds and close to water of some lind, chiefly 
in the southern counties of England, is said to be chosen by the Marsh Warbler for its nest. It employs grassstems and leaves, moss and spiders' webs, in the construction of its nest, with an inner lining of horsehair. The eggs number from five to seven, and vary considerably in coloration. One type is said to be greenish-white, spotted, blotched, and marbled with olive-brown, and another greenish-blue, blotched and spotted with olive-brown and grey underlying marks. It is a rare and local breeder with us.

\section{THE SNOW BUNTING.}

THe highest mountain-tops of Scotland and the Shetlands are patronised by the Snow Bunting during the breeding season. It makes its nest of withered grass, fine roots, and moss, and lines it with down, wool, hair, or feathers, and situates it in crevices of rock or amongst loose stones. The egrgs number from four to eight, but five or six are generally found, varying from dull white to very light greenish-blue in ground colour, spotted and blotched with reddish-brown, and occasionally streaked with blackishbrown. The markings are most numerous at the larger end, and the underlying ones are of a light grey and pale brown.

\section{THE SPOTTED CRAKE.}

TuE eastern and southern counties of England are the favourite breeding resorts of this somewhat uncommon birl. Its nest is large, and made of reeds, sedges, rushes, and other materials growing in swamps, and is placed on a 



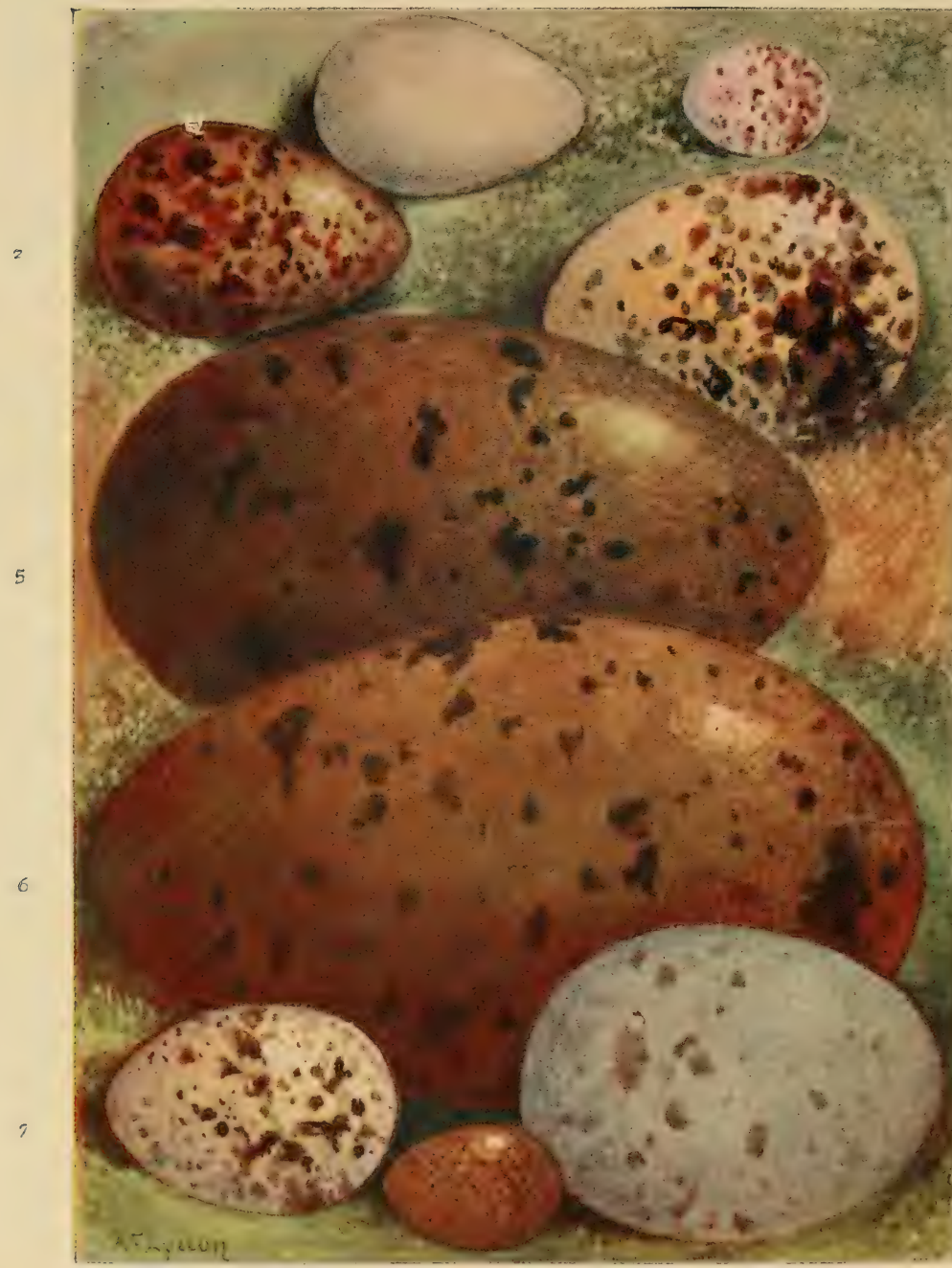

\section{EGGS.}

x. Hoopoe. 2. Red-necked Phalarope. 3. Crested Tit.

4. Common Tern. 5. Red-throated Diver. 6. Black-throated Diver. 7. Lesser Tern. 8. Montague's Harrier. 9. Sedge Warbler. 
tussock or amongst reeds, the base generally resting in water. The eggs number eight to ten, and even twelve, and vary in ground colour from white to buff, the intermediate stages including olive and greenish-white. They are spotted with reddish-brown of varying shades, and grey.

\section{THE RED-THROATED DIVER.}

I mave seen this bird's nest in the Outer Hebrides, where it is fairly common. It also breeds on the mainland of Scotland and in Ireland. The nest is generally placed close to the edge of some mountain tarn or loch, and is a mere depression trodden in the peat earth, sometimes scantily lined with bits of dead bent or water-weeds. The eggs number two, of a dark brownish-olive, frequently greenish, spotted with blackish-brown, and underlying markings of a lighter character.

\section{THE BLACK-THROATED DIVER.}

T're Black-throated Diver breeds in the Outer II and on the mainland of Scotland. It places its nest, which is made of reeds and aquatic weeds, lined with grass, on the shingle of mountain-loch shores and small islands. The eggs number two, dark olive-brown, or buffish-brown, spotted somewhat sparingly with blackish-brown and umber-brown. The eggs need careful identification, else they are likely to be confused with those of the Redthroated species. 



\section{INIEX.}

$\Lambda$

Auk, Little, 69

B

Bittern, 33

Blackbird, 29

Blackicap, 46

Black Redstart, 52

Blue Tit, 46

Brambling, 63

Bullfinch, 22

Bunting, Blackheaded, 65

, Cirl, 60

, Common, 56

, Snow, 90

Buzzard, 60

\section{C}

Capercailzie, 35

Carrion Crow, 44

Chaffinch, 23

Chiffchaff, 51

Chough, 58

Cirl Bunting, 60

Cole Tit, 68

Coot, 55

Cormorant, 66

Crake, Spotted, 90

Creeper, 66

Crossbill, 32

Crow, Carrion, 44

, Hooded, 55

Cuckoo, 48
Curlew, Common, 5.5

" Stone, $7 j$

\section{D}

Dartford Warbler, 61

Dipper, 52

Diver, lied-throated, 91

,, Black-throated, 91

Dotterel, 69

Dove, Ring, 26

„ Rock, 69

, Stock, 61

, Turtle, 66

Duck, Eider, 43

× -, Wild, 47

,, Tufted, 75

,, Pintail, 83

Dunlin, 36

$$
\text { E }
$$

Eagle, Golden, 43

"White-tailed, 42

Eider Duck, 43

Falcon, Gyr, 57

,, Peregrine, 54

Fieldfare, 57

Flycatcher, Pied, 36

" Spotted, 62

G

Gadwall, 75

Gannet, 67

Garden Warbler, 53 
Garganey, 76

Golden-crested Wren, 27

Golden Eagle, 43

, Plover, 37

Goldfinch, 21

Goose, Grey Lag, 73

Goosander, 77

Gosharvk, 73

Grasshopper Warbler, 43

Grebe, Little, 35

, Great Crested, 77

Greenfinch, 28

Greenshank, 80

Green Woodpecker, 30

Grey Wagtail, 64

Grouse, Red, 25

Black, 89

Guillemot, Common, 68

$$
\text { , Black, } 77
$$

Gull, Blackheaded, 50

" Common, 30

," Herring, 44 ।

„, Great Black-backed, 89

,, Lesser Black-backed, SS

Gyr Falcon, 57

$\mathrm{H}$

Harrier, Montagu's, 86

$$
\begin{array}{ll}
" \quad \text { Hen, } 87 \\
" \quad \text { Marsh, } 87
\end{array}
$$

Hawfinch, 61

IIawk, Kestrel, 2 ๖

," Merlin, 33

, Sparrow, 45

Hedge Sparrow, 52

Heron, 49

Hobby, 87

Hooded Crow, 55

Hoopoe, 81

House Sparrow, 25

Jackdaw, 25
Jack Snipe, 57

Jay, 24

Kestrel, 25

Kingfisher, 30

Kite, 39

Kittiwake, 78

Landrail, 38

LLapwing, 31

Lark, Shore, 67

, Sky, 37

, Wood, 32

xLesser Whitethroat, 41

Linnet, 23

\section{M}

$\times$ Magpie, 22

Marsh 'Tit, 69

Martin, House, 51

* , Sand, 39

Meadow Pipit, 35

Merlin, 33

Merganser, Red-breasted, 79

Missel Thrush, 53

Moorhen, 31

iv

Nightingale, 31

$\times$ Nightjar, 33

Nuthatch, 29

Oriole, Golden, 85

Osprey, 85

Ouzel, Ring, 59

, Water, 52

Owl, Barn, 31

" Long-eared, 40

"Short-eared, 78

", Tawny, 43

Oyster-catcher, 68 


\section{$\mathrm{P}$}

Partridge, 46

, Red-legged, 70

Peregrine Falcon, 54

Petrel, Stormy, 34

, Fulmar, 76

", Leach's Fork-tailed, 84

Phalarope, Grey, 42 " Red-necked, 84

Pheasant, 48

Pied Flycatcher, 36

X " Wagtail, 48

Pintail Duck, 83

Pipit, Meadow, 35

" Rock, 65

" Tree, 36

Plover, Golden, 37

x $"$ Green, 31

" Kentish, 60

" Ringed, 82

Pochard, 62

Ptarmigan, 54

Puffin, 58

Quail, 67

Q

$\mathrm{R}$

Rail, Land-, 38

" Water, 56

Raven, 23

Razor-bill, 71

Red-backed Shrike, 58

Red-legged Partridge, 70

Redpoll, 26

Redshank, 39

Redstart, 28

Redwing, 40

Llack, 62

Ringdove, 26

Ring. Ouzel, 59

Robin, 26
Rock Dove, 69

, Pipit, 65

Rook, 24

Ruff, 41

S

Sanderling, 70

Sand Martin, 39

Sandpiper, Common. 41

Scoter, 64

Seagull, Common, 30

Shag, 74

Shearwater, Manx, S3

Shieldrake, 40

Shore Lark, 67

Shoveller, 42

Shrike, Red-backed, 58

Siskin, 27

Skua, Common, 38

, Richardson's, 88

Skylark, 37

Smew, 65

Snipe, Common, 50

" Jack, 57

X.Sparrowha wk, 45

$\times$ Sparrow, Hedge, 52

* " House, 25

" Tree, 63

Spoonbill, 54

Spotted Flycatcher, 62

Starling, 22

Stint, Little, 39

Stock Dove, 61

Stone-chat, 34

Storm Petrel, 34

Sivallow, 44

Swan, Mite, 74

Siwift, 50

T

Teal, 29

Tern, Sandwich, 71 
Tern, Arctic, 72

"Common, 72

" Lesser, 72

, Roseate, $\mathrm{S} 2$

Thrush, Common, 28 " Missel, 53

'Tit, Blue, 46

,, Bearded, 82

"Cole, 68

"Great, 29

" Long-tailed, 70

"Narch, 69

„ Crested, 74

Tree Pipit, 30

,Sparrow, 63

$\times$ Turtle Dove, 66

Twite, 87

W
Wagtail, Grey, 64
" $\quad$ Tied, 48
" Yellow, 73
Warbler, Dartford, 61
" $\quad$ White, 85
Blue-headed, 86
, Garden, 53
$\because \quad$ Grasshopper, 43

Warbler, Marsh, 89

„ lieed, 80

$\times \quad$ " Sedge, 79

Water Ouzel, 52

" Rail, 56

Wheatear, 34

Whimbrel, 80

Whinchat, 64

White-tailed Eagle, 42

Whitethroat, 27

- Lesser, 41

Wigeon, 38

Wild Duck, 47

Woodcock, 49

Woodlark, 32

Woodpecker, Green, 30

" Great Spotted, 65

, Lesser Spotted, 78

Wood Warbler, 81

Wren, Common, 24

" Golden-crested, 27

¿ Willow, 79

Wryneck, 27

$\mathrm{Y}$

Yellow-hammer, 56 


\section{Works by R. KEARTON, F.z.S.,}

With Illustrations from Photographs taken direct from Nature by C. and R. Kearton.

The Adventures of Cock Robin and

His Mate. IVith upwards of I 20 Illustrations. 6s.

"A delightful Nature book."-Daily Graphic.

"We cannot praise the book too highly for every lover of country life and Nature, whether old or young." -Britis/ Weekly.

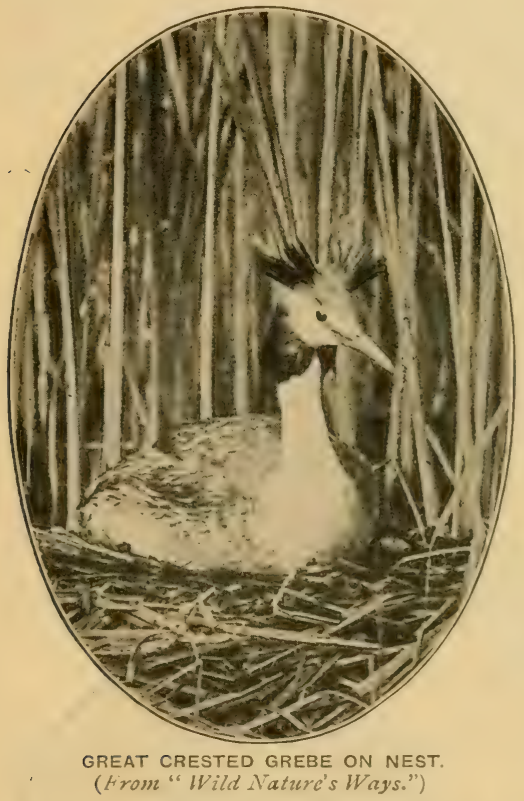

\section{$\varnothing \varnothing$ \\ Wild \\ Nature's \\ Ways.}

With 200 beautiful Illustrations. Ios. $6 \mathrm{~d}$.

"A mine of marvels, more fascinating than any romance."

- Pall Mall Gazette.

\section{White's Natural History of Selborne.}

With Notes by R. KE.lrton, F.Z.S. Containing upwards of r 20 Illustrations. $6 \mathrm{~s}$.

"Old Gilbert himself would have been delighted with this pretty rolume. than which no better gift for a lad with a taste for natural history can well be imagined. It is to be regretted that the pictures do not convey to the reader any idea of the infinite pains and cunning which have been necessary. to obtain them."-Daily" Telegraph.

CASSEL L \& COMPANY, Linited, I ondon; and all Booksellers. 


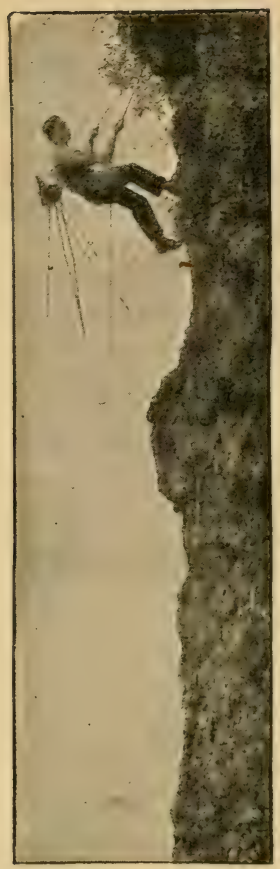

DESCENDING A CLIFF TO PHOTOGRAPH AN EAGLE'S EYRIE.
Works by R. KEARTON, F.Z.S.

Illustrated from Photographs direct from Nature by C. KEARTON.

\section{Strange Adventures in Dicky-Bird}

Land: Stories Told by Mother Birds to Amuse their Chicks, and Overheard by R. Kearton, F.Z.S. With Rembrandt Frontispiece and numerous Illustrations. 3s. 6d.; cloth gilt, $5 \mathrm{~s}$.

"Here is a book to make a child's mouth water. The print is large and clear, the language is simple, the pictures are excellent, and, combined with the letterpress, will give the bird-loving child an immense amount of instruction."Country Life.

\section{$* *$}

\section{Our Rarer British Breeding Birds :}

Their Nests, Eggs, And Summer Haunts. Profusely Illustrated. Cheap Edition, 3s. 6d. net.

"A most valuable contribution to ornithological literature."-Daily News.

With Nature and a Camera. By RICHARD KEARTON, F.Z.S. Illustrated by a Special Frontispiece and I 80 Pictures from Photographs direct from Nature by C. KeARTON.

Cheap Edition, 7s. 6d.

.' With Nature and a Camera' surpasses the sensations of the most romantic of novels, and is lavishly embellished with photographic re productions of exquisite softness and delicacy." - The Times.

\section{$* * *$}

\section{Nature}

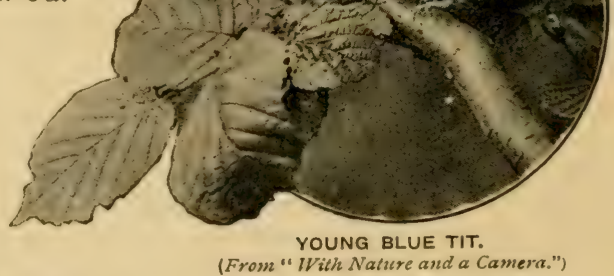

CASSELL \& COMPANY, Limited, London; and all Bcoksellers. 


\section{Works by R. KEARTON, F.Z.S.}

With Illustrations from Photographs taken direct from Nature by C. KEARTON.

Our Bird Friends. Their Fond, Feathers, Flight, Nests, Eggs, Young, Songs and Call Notes. With Ioo Illustrations from Photographs. Cloth gilt, 5 s.

"It is without exception the most delightful book on bird life that we have seen. The photographs are amusing, interesting, and instructive alike."-Pall Mall Gazette.

Wild Life at Home: How to Stuny axd PhotoGRAPH IT. $6 \mathrm{~s}$.

"This delightful book deserves a wide popularity."-Nature.

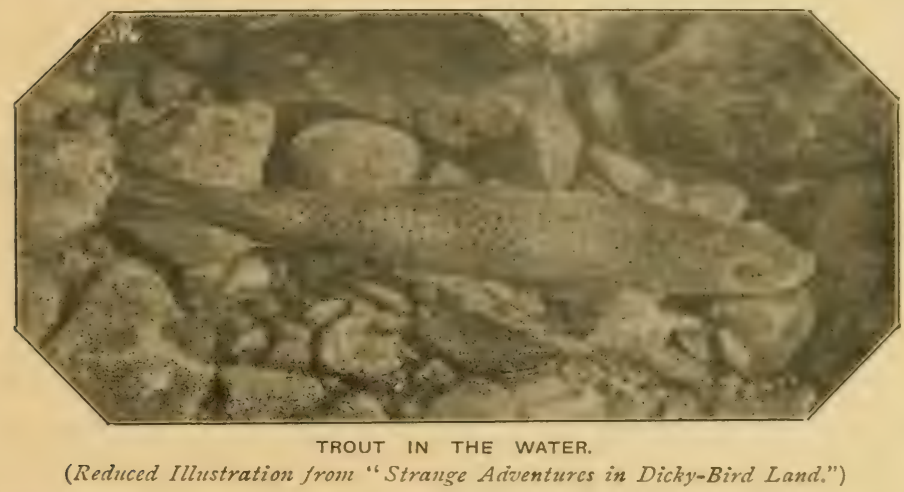

British Birds' Nests : How, IVhere, and When to Find And IDENTIFy Thenr. With nearly 130 Illustrations of Nests, Eggs, Young, etc. 2 Is.

"Mr. Kearton's book is an interesting success, a painstaking and meritorious attempt to illustrate worthily an important province of British ornithology."-Academy.

\section{Birds' Nests, Eggs, and Egg=-eollecting. Illus-} trated with 22 Coloured Plates of Eggs. $5 \mathrm{~s}$.

"This well-written, daintily got up, and beautifully illustrated volume is altogether exceedingly attractive, and will serve as an excellent and tasteful gift-book."-Public Opinion.

CASSELl \& COMPANY, Limited, Ludgate Hill, London. 


\section{POPULAR WORKS ON NATURAL HISTORY.}

\section{The Butterflies and Moths of Europe.}

By W. F. Krrby, F.E.S., F.L.S. With 54 Coloured Plates and numerous Illustrations. 2 Is. net.

The Field Naturalist's Handbook. By the Rev. J. G. WOOD and the Rev. THEODORE WOOD. Is.; cloth, Is. 6d. ; interleaved for notes, $2 \mathrm{~s}$.

Familiar Wild Flowers. By Prof. F. Edward Hulne, F.L.S., F.S.A. Each Volume contains 40 exquisite Coloured Plates. In Eight Volumes, 3s. 6d. each.

Familiar Garden Flowers. By Prof. F. Edward Hulme, F.L.S., F.S.A. With 40 Full-page Coloured Plates in each Volume, and Descriptive Text by SHIRLEY HibBerd. Five Vols., 3s. 6d. each. In paste grain, 5 Vols. in box to match, 2 Is. net.

Familiar Butterflies and Moths. By W. F. Kirkey, F.L.S., F.E.S., Assistant in the Zoological Department, British Museum. Illustrated with is magnificent Coloured Plates. 6s.

Familiar Wild Birds. By W. Swaysland. With Coloured Pictures by A. ThORBURn and others. Complete in 4 Vols., 3s. 6 d. each.

Popular History of Animals. By Hexry Scherren, F.Z.S. With in Coloured Plates and numerous other Illustrations. $6 \mathrm{~s}$.

Cassell's Natural History. Edited by P. Mirtin Duncan, M.B., F.R.S., F.G.S. With about 2,000 Highclass Illustrations. Chent Edition. Complete in Three Double Vols., price 6s. each.

Cassell's Concise Natural History. By Prof. E. Perceval Wright, M. Coloured and Plain Plates. 6s.

Eyes and No Eyes. By Arabelia Buckiev. With numerous Original Illustrations and Coloured Plates. Cloth, 3s. 6d. 


\section{$2 \sqrt{5}$}

A SELECTION

FROM

CASSELL \& COMPANY'S

PUBLICATIONS.

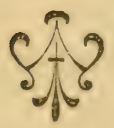




\section{Illustrated, Fine Art, and other Volumes.}

ADAMS (Prof. HENRY), M Inst.C.E. Building Construction. 7s. 6d. net.

ARNOLD-FORSTER (The Rt. Hon. H. O., M.A.)-

A History of England, Fully Illustrated, 5s. Gilt edges, 6s. $6 \mathrm{~d}$.

\section{ARTISTS, POPULAR MODERN-}

1. Sir Lawrence Alma - Tadema, O.M., R.A. By PERCY CROSS StANDING. With Coloured Plate and other Illustrations. 55. net.

2. Henrietta Rae (Mrs. Ernest Normand). By AR'SHUR FISH. With Coloured Plates and other Illustrations. 55. net.

3. Stanhope Forbes, A.R.A., and Elizabeth Forbes, A.R.W.S. By Mrs. L. BIRCH. 53. net.

BACON (Rev. J. M.)-

The Dominion of the Air: The Story of Aërial Navigation. Popular Edition, 35. 6d.

BALL (Sir ROBERT, LL.D.)-

The Earth's Beginning. Illus. trated. 7s, 6d.

The Story of the Heavens. With Coloured Piates. ros. $6 \mathrm{~d}$.

Star-Land. Illustrated. 7s. 6d.

The Story of the Sun. With Eight Coloured Plates and other Illustrations. 7s. 6d.

BARRIE (J. M.) -

Tommy and Grizel. 6s.

The Iittle Minister. Illustrated. Cheap Edition. 3s. 6d. Pocket Edition, cloth, 2s. net; leather limp, 3s. net.

Sentimental Tommy. $6 \mathrm{~s}$.

BLOUNDELLE-BURTON (J.)-

The Sword of Gideon. 6s.

BONNEY (Prof., F.R.S.)-

The Story of Our Planet. With Coloured Plates and Maps and about 100 lllustrations. Chexp Edition. 75, 6d.

Britain at Work. A Pictorial Description of our National Industries. With nearly 500 Illustrations. I2s.

British Isles, The. Depicted by Pen and Camera. With a Series of Coloured Plates and a profusion of Illustrations from Photographs. Complete in 3 Vols., each containing about 400 Illustrations and 12 Coloured Plates, 2Is. net each.
BUCKLAND (ANNA)-

The Story of English Literature.

Kevised and brought up to date. 35. $6 d$.

\section{BURTON (WM.) -}

English Earthenware and stone-

ware. Containing 24 Plates in Colours and 54 Black and White Plates, 3os. net. This Edition is limited to $r, 450$ copies.

French Porcelain. By E. S. Aus. CHER. Translated and edited by WM. Burton. With 24 Plates in Colours and 54 Black and White Plates. 3os. net. This edition is limited to 250 copies.

Cassell's Cabinet Cyclopædia. Concise and comprehensive. With several hundred Illustrations and Diagrams. Cloth, 7 s. $6 \mathrm{~d}$.; halfleather, ros. $6 \mathrm{~d}$.

Cassell's New Dictionary of Cookery. With about I0,000 Recipes and a Series of Coloured Plates. Cloth, 7s. 6d. ; half-leather, ros. 6d. .

Chums. The Illustrated Paper for Boys. Yearly Volume, 8s.

COLLIER (The Hon. JoHN)The Art of Portrait Painting. With $\mathrm{r}_{4}$ Reproductions in Colour and 27 in Black and White. Ios. $6 \mathrm{~d}$. net.

CRANE (WALTER, R. W.S.)A Flower Wedding. With 40 Pages of Iilustrations in Colours, $6 \mathrm{~s}$.

COX (Sir Edmund, Bart.)John Carruthers: Indian Policeman. Illustrated. 3s. od.

DANE (JoHN COLIN)The Hidden House. $6 s$.

DIOSY (ARTHUR, F.R G.S.) The New Far East. Popular Edition. Illustrated. 35. 6d.

Don Quixote, The Doré. With about 400 Illustrations by GUSTAVE DORÉ. IOS. 6d.

Doré Dante, The. Comprising the Inferno, Purgatory, and Paradise. Illustrations by GUSTAVE DORÉ. Vol. I contains the Interno, Vol, 2 Purgatory and Paradise. r6s. net 
Doré Dante. Continued-

each. Pocket Edition of the Inferno, cloth, 2s. net ; leather limp, 3s, net.

Doré Gallery, The. With 250 Illustrations by GUSTAVE DORÉ. 42 .

Doré's Milton's Paradise Lost. Illus. trated by DORE. Fine Art Edition, r6s. net. Popular Edition, Cloth or Buckram, 7s. 6d. Large 4to, I2s. 6d.

Duval's Artistic Anatomy. New and Revised Edition, edited and amplified by A. M. PATERSON, M.D., Derby Professor of Anatomy in the University of Liverpool. With numerous Illustrations. $5 \mathrm{~s}$. net.

En'cyclopædic Dictionary, The. New Edition. 8 vols., ros. 6d. each.

Family Doctor, Cassell's. 6s.

Family Lawyer, Cassell's. Ios. 6d.

FAWCETT (Mrs. HENRY, LL.D.)Five Famous French Women. Illustrated, $6 \mathrm{~s}$.

FISH (ARTHUR) -

Henrietta Rae (Mrs. Ernest Normand). With Coloured Plate and other Illustrations. $5 \mathrm{~s}$. net.

FLETCHER ( J. S.)Highcroft Farm. $6 \mathrm{~s}$.

FOWLER (ELLEN THORNEYCROFT)

(Mrs. A. L. Felkin).

Verses Wise and Otherwise. With which are incorporated "Verses Grave and Gay." 5s.

PRASER (JOHN FOSTER)Canada as It is. Illustrated. 6s. The Real Siberia. "With numerous Illustrations. $3 \mathrm{~s}$. $6 \mathrm{~d}$.

America at Work Illustrated. 3s. $6 \mathrm{~d}$

Pictures from the Balkans. $6 \mathrm{~s}$.

FREEMIAN (RICHARD AUSTIN)The Golden Pool. 6s.

GERARD (MORICE)-

The Red Seal. Es. Adventures of an Equerry. 6s. A Lieutenant of the King. $6 \mathrm{~s}$.

GORST (MrS. HAROLD)The Light. $6 \mathrm{~s}$.

Great Pictures in Private Galleries. A selection of the most famous Modern Pictures in the Private Galleries of Great Britain reproduced in Colours. Two Series, each containing 48 Pictures, mounted on specially selected art paper, I2S. or half-leather, $15 \mathrm{~s}$.
GRIFFITHS (Major ARTHUR) -

Fifty Years of Public Service. With Portrait. Popular Edition, 6s. net.

HAGGARD (RIDER)-

The Brethren: A Romance of the Crusades. $6 \mathrm{~s}$.

King Solomon's Mines. Illustrated, 3s. 6d. Gift Book Edition. $6 s$.

HASLUCK (PAUL N.)-

Cheap Dwellings. Illustrated. Is. net.

The Handyman's Book of Tools, Materials, and Processes employed in Woodworking. Edited by. With about 2,500 Illustrations. 9s.

Cassell's Cyclopæcia of Mechanics. Edited by. Profusely Illustrated. 4 Series, each complete in itself. 75. 6d, each.

Metalworking: A Book of Tools, Materials, and Processes for the Handyman. Edited by. With Illustrations. 9s.

The Book of Photography. Practical, Theoretic, and Applied. Edited by. Illustrated. Ios. 6d.

"Work" Handbooks. Edited by. 37 vols. Illustrated. Is, net each. \&c., \&c.

HERING (HENRY A.)-

The Burglars' Club, 3s, 6d.

HOCKING (JOSEPH)-

A Flame of Fire. New Illus. trated Edition. 35. 6d.

HOCKING (SILAS)-

A Human Face. 3s. 6 d.

Home Handbooks, Cassell's. Paper covers, Is. net each. Cloth, Is. 6d. net each.

The Home Lawyer. The Home Physician. Vegetarian Cookery. Cookery for Common Ailments. Our Sick and How to Take Care of Them. The Making of the Home.

HULME (F. E., F.L.S., F.S.A.)-

Familiar Garden Flowers. With 200 Full-page Coloured Plates. In Five Vols., 3s. 6d. each.

Familiar wild Flowers. With 320 beautiful Coloured Plates. Cheap Edition. In Eight Volumes. 3s. 6d. each. 
HUME (FERGUS)-

The Mystery of the Shadow. 3. $6 \mathrm{~d}$.

KEARTON (R., F.Z.S.)-

Illustrated from Photographs Direct from Nature by C. and R. KEARTON.

Pictures from Nature. Being I5 Reproductions in the finest Rembrandt Photogravure from negatives made direct by RICHARD and CHERRY KEARTON of birds and beasts in their native haunts. Ios. $6 \mathrm{~d}$.

The Adventures of Cock Robin and His Mate. Ss.

British Birds' Nests. 2Is.

$\sqrt{ }$ Our Rarer British Breeding Birds. 3 s. 6 d.

With Nature and a Camera. With 180 Pictures. 7s. 6d.

our Bird Friends. $5 \mathrm{~s}$.

Wild Nature's Ways. 6s.

Strange Adventures in DickyBird Land. 3s. 6d. ; cloth giit, gilt edges, 5 s.

White's Natural History of Selborne. Illustrated. With Notes by R. KEARTON. 6s.

Wild Life at Home: How to Study and Photograph It. 6s.

$\checkmark$ Birds' Nests, Eggs, and Egg-Collecting. With 22 Coloured Plates. $5 \mathrm{~s}$.

KENNEDY (BART)-

In a Tramp Camp. $6 \mathrm{~s}$.

KIRBY (W. F., F.L.S., F.E.S.)The Butterflies and Moths of Europe. With 54 Coloured Plates and numerous Illustrations. 2Is. net. Familiar Butterflies and Moths. With I8 Coloured Plates. 6s.

LE QUEUX (WILLIAM)The Spider's Eye. 6s.

The Woman at Kensington. 6s.

I.ondon, Cassell's Guide to. Illustrated. New Edition, paper, 6d. Cloth, rs.

LOW AND PULLING-

English History, Dictionary of. Edited by SIDNEY Low, B.A., and Prof. S. Pulling, M.A. 7s. 6d.

MacWHIRTER (J., R.A.)-

Landscape Painting in waterColour. 23 Coloured Plates. 5 s.

MCCAUL (ETHEL)- -

Under the Care of the Japanese

War Office. Illustrated, $6 \mathrm{~s}$.
MILES (EUSTACE, M.A.)Cassell's Physical Educator. With I,000 Illustrations. 9s.

MORLEY (Prof. HENRY)-

English Writers. Vols. I. to XI. 5s. each.

The Plays of Shakespeare. Edited by Professor Henry Morley. Complete in Thirteen Vols., cloth, 2Is.

Music, Cassell's Popular. A Series of Songs and Pieces of Music. 2d. net each.

National Gallery of British Art, The (The Tate Gallery). With an Introduction by Sir CHARLES HOLROYD, and containing 24 Exquisite Rembrandt Photogravure Plates, and beautiful reproductions of the principal pictures. Cloth, r2s. Leather back, cloth sides, I5s.

National Library, Cassell's. In 108 volumes, $6 \mathrm{~d}$. net each.

Nation's Pictures, The. Complete in 4 Vols. Each containing 48 Beautiful Coloured Reproductions with descriptive Text. Cloth, I2s. ; halfleather, I5s. each.

Natural History, Cassell's. Cheap Edition. With about 2,000 Illustrations. In Three Double Vols. 6s. each.

Natural History, Cassell's Concise. By E. Perceval Wright, M.A., M.D., F.L.S. With several Hundred Illustrations. $6 \mathrm{~s}$.

PASTURE (MrS. HENRY DE LA)A Toy Tragedy. 3s. $6 \mathrm{~d}$.

PEMBERTON (MAX)The Hundred Days. 6s,

The Giant's Gate. $6 \mathrm{~s}$. The Impregnable City. 35. 6d. Kronstadt. Pocket Edition, Cloth, 25. net; leather limp, 3 s. net.

*Red Morn. $6 \mathrm{~s}$.

The Iron Pirate. 3s. 6d. Pucket Edition, cloth, 2S. net; leather limp, 3s. net.

The sea Wolves. 35.6 .

The Garden of Swords. 6s. ;

*also People's Edition at 6d.

Postcards, Cassell's Art. 10 Series, 6 d. each. List on application.

QUILTER-COUCH (A.T.)-

THE SHIP OF STARS. 6S.

ADVENTURES OF HARRY REVEL,

THE LAIRD'S LUCK. $6 s$.

+'DEAD MAN'S ROCK. 5 s.

t"THE SPLENDID SPUR. 55 .

- Also at 3s. 6d. †Also Peoples Editions at $6 \mathrm{~d}$. 
QUILLER-COUCH(A.T.). Continued-

ITHE ASTONISHING HISTORY OF TROY TOWN. 5S.

"I SAIV THREE SHIPS," and other Winter's Tales. 5s,

IA: A LOVE STORY. 35 6d.

NOUGHTS AND CROSSES,

THE DELECTABLE DUCHY. $5 S$.

WANDERING HEATH. $5 \mathrm{~S}$.

+ Also Peopie's Eations at 6 d.

Adventure Books, The Red, The Green, The Blue, The Brown, The Black, and The Grey. Edited by. Each complete in itself, and containing a series of Stories from "The World of Adventure." Profusely Illustrated. 5s. each.

Railway Guides, Official. With Illustrations, Maps, \&c. Price Is. each ; or in cloth, IS. 6 d, each.

LONDON AND NORTH WESTERIN RAILWAY. GREAT WESTERN RAILWAY.

MIDLAND RAILWAY.

GREAT NORTHERN RAILWAY.

GREAT EASTERN RAILWAY.

LONDON AND SOUTH WESTERN RAILWAY.

LONDON, BRIGHTON, AND SOUTH COAST RAILWAY.

SOUTH EASTERN AND CHATHAM RAILWAY.

Reid (Sir WEMYSS)-

Black, William, Novelist. With 3 Portraits. Ios. 6d. net.

REID (STUART J.) -

Sir Wemyss Reid's Memoirs. 1842-1885. With Portrait, I8s. net.

Royal Academy Plctures. Annual Volume. Cloth, 5s, net. Paper covers, 3s. net.

SCHERREN (HENRY, F.Z.S.)The Zoologica,l Society of London. With I2 Coloured Plates and about 50 in Black and White. 3os. net. This edition is limited to $\mathbf{I}, 000$ copies.

Shakspere, The Leopold. With 400 Illusirations. Cheap Edition, 3s.6d. Cloth gilt, gilt edges, $5 \mathrm{~s}_{\mathrm{*}}$; halfpersian, 5s. 6d. net.

Shakspere, The Royal. With 50 Full-page Illustrations. Complete in Three Vols. I5s. the set.

SIMPSON (FRANCES)-

The Book of the Cat. I5s. net.

Social England. By Various Writers. Edited by $\mathrm{H}$. D. TRAILL, D.C.L., and J. S. MANN, M.A. Library Edition. Six Vols. I4S. net each.

SPIELIMANN (M. H.)-

Ruskin, John: A Sketch of His Life, His Work, and His Opinions, with Personal Reminiscences. 5s.

Standard Library, Cassell's. Is. net each. (List free on application.)
STANDING (PERCY CROSS)Sir Lawrence Alma-Tadema,0.M., R.A. With Coloured Plate and other Illustrations. 5 s. net.

The Hon. F. S. Jackson. 2s, 6d.

STANTON, C., and HOSKEN, H.-

Miriam Lemaire, Money Lender. 3s. $6 \mathrm{~d}$.

STEVENSON (R. L.)-

Library Edition, 6s. Popular Edition, 35. 6d. Pocket Edition, 25. net; leather, 35. net.

The Black Arrow. Catriona. Kidnapped. Master of Ballan. trae. Treasure Island. The Wrecker.

Thames and its Story, The. 6s.

TREVES (Sir FREDERICK, Bart., G.C.V.O., \&c. \&. .) -

The Other Side of the Lantern. With 40 Full-page Plates. I2s. net.

Turner, J. M. W., R.A., The WaterColour Sketches of, in the National Gallery. With $5^{8}$ Facsimile Reproductions in Colour. With Descriptive'Text by'THEODORE A. Cook, M.A., F.S.A. £3 3s, net.

WALLACE (Sir D. MACKENZIE) Russia. With 2 Maps. 2 Vols., 245. net.

WALMSLEY (R. MULLINEUX, D.Sc.) -

Electricity in the Service of Man. With $x, 200$ Illustrations, ros. 6 d. net.

WRIGHT (LEWIS) -

The New Book of Poultry. With 30 Coloured Plates by J. W. Ludlow, and other Illustrations. 2rs.

WRIGHT (WALTER P.)-

Cassell's Dictionary of Practical Gardening. Edited by. With 20 Coloured Plates and numerous Illustrations. Two Vols., 30s, net.

Cassell's Popular Gardening. Edited by. With 24 Coloured Plates and numerous lllustrations. 2 Vols., 30s. net.

Pictorial Practical Flower Gardening. With about roo Illustrations. Is. net ; cloth, Is, $6 \mathrm{~d}$. net:

* * Separate List of the "Pictorial "Praciical " Handbooks issued.

WYLLIE (W. L., A.R.A.)-

Marine Painting in Water-Colour. With 24 Coloured Plates. 5s.

WILCOX (ELLA WHEELER) -

A Woman of the World. $6 \mathrm{~s}$. 


\section{Bibles and Religious Works.}

Bibie Biographies. Illus. Is, 6d. each. THE STORY OF MOSES AND JOSHUA. By the Rev. J. Telford.

THE STORY OF THE JUDGES. By the Rev. I. Wy cliffe Gedge.

THE STORY OF SAMUEL AND SAUL. By the Rev. D. C. Tovey.

THE STORY OF DAVID. By the Rev, J. IVild. THE STORY OF JOSEPH. Its Lessons for To-day. By the Rev. George Bainton.

THE STORY OF JESUS. In Verse. By J. R. Macduff, D.D.

Cassell's Family Bible. With Explanatory Notes, Maps, References, and a Condensed Concordance. Illustrated with more than 900 highly finished Engravings. Full leather, gilt edges, 25s. net ; superior leather, with clasps and corners, 3Is. 6d. net.

Cassell's Family Bible. With 900 Illustrations. Toned paper edition. Leather, gilt edges, $£_{2}$ Ios.

\section{ELIICOTT (Dr.)-}

Bible Commentary for English Readers. Edited by. With Contributions by eminent Scholars and Divines :-

Nhw Testament, Popular Edition. Unabridged. Three Vols. 6s, each.

OLD THSTAMENT. Popular Edition. Unabridged. Five Vols. $6 \mathrm{~s}$, each.

SPECIAL POCKET EDITIONS OF THE NEW TESTAMENT VOLUMES, 2s. each; leather limp, 2s, 6d, net each.

\section{FARRAR (Dean)-}

The Life and Work of St. Paul. Cheap Edition. With r6 Full-page Plates, 3s. 6d.; paste grain, $5 \mathrm{~s}$. net; Popular Edition, 75. 6d.; New Illustrated 4to Edition, ros. 6d. net; Original Illustrated Edition, $f^{2} 2 \mathrm{~s}$.

The Early Days of Christianity. Library Edition. Two Vols., 24. ; morocco, f2 2s. Popular Edition. Complete in One Volume. Cloth, gilt edges, 7s. 6d. Cheap Edition, cloth gilt, 35 . $6 \mathrm{~d}$. ; paste grain, $5 \mathrm{~s}$. net.

The Life of Christ. Cheap Edition. With 16 Full-page Plates. 3s. 6d.; paste grain, 5s. net. Illustrated Quarto Edition, Bivgraphical Edition, Ios. 6d. net. Original Illustrated Edition, 2Is.

Life of Lives, The: Further Studies in the Life of Christ. I5s. Popular Edition, 75. 6d.

\section{GALE, F. HOLDERNESS-}

The Story of Protestantism. 6s.
GEIKIE (Rev. CunninghaM, D.D.) Holy Land and the Bible. Cheat Edition, 7s. 6d. Superior Edi. tion. With 24 Plates. Cloth gilt, gilt edges, Ios. 6d. "Quiver" Edition. With 8 Full-page Illus. trations, 2s. 6d. net.

HUNTER (Rev. ROBERT, LL.D.)Cassell's Concise Bible Diction. ary. Illustrated. Cheap Ediiion, 3s. $6 \mathrm{~d}$.

Iife and Work of the Redeemer. By Rev. H. D. M. SPENCE, D.D., Most Rev. W. AleXaNdER, D.D., Prof. Marcus Dods, D.D., Rt. Rev. H. MOULE, D.D., Rev. LYMAN ABBot, D.D., Rev. F. B. MEYER, B.A., Right Rev. W. BOyd CARPENTER, D.D., Very Rev. W. Lefroy, D.D., Rt. Rev. W. C. DOANE, D.D., Rev. JAMES Stalker, D.D., Rev. A. M. FAIRBAIRN, D.D., and Rev. Alex. MCLAREN, D.D. Illustrated. "Quiver" Edition. With 8 Full-page Illustrations, 2s. 6d, net.

MAGEE (WM. CONNOR, D.D.), late Archbishop of York-

The Atonement. Is.

MAITLAND (Rev. BRoWNLOW, M.A.) Miracles. Is.

Quiver. Yearly Volume, With about 800 Original Illustrations, I4 Coloured Plates, and 2 Rembrandt Photogravures; also Serial Stories by Popular Writers, about 40 Complete Stories, \&c. 7s. 6d.

SPENCE (Very Rev. H. D. M., D.D., Dean of Gloucester)-

The Church of England. A History for the People. Illustrated. Complete in Four Vols. 6s. each. Early Christianity and Paganism. Illustrated. Cheap Edition. 7s. 6d. The Child's Bible. With roo Illustrations and Coloured Plates. New Edition. ros. 6d.

The Child "Wonderful." A unique Series of Pictures representing Incidents in the Early life of the Saviour, reproduced in colour with accompanying text. By W. S. STACEY.

WYLIE (Rev. J. A., LL.D.)The History of Protestantism. Containing upwards of 600 Orig. inal Illustrations. Cheap Edition. Three Vols. 5s, each. 


\section{Educational Works and Students' Manuals.}

Esop's Fables. In words of one syllable. With 4 Coloured Plates and numerous Illustrations. $6 d$.

Blackboard Drawing. By W. E. SPARKES. Illustrated. 3S. 6d.

Book-Keeping. By THEODORE JONES. For Schools, 2s. ; cloth, 3s. For the Million, 2s. ; cloth, 35. Books for Jones's System, 2s.

Chemistry, The Public School. By J. H. ANDERSON, M.A. 2s. $6 \mathrm{~d}$.

"Eyes and No Eyes" Series (Cas. sell's). By ARABELLA BuCKLEY. With Coloured Plates and other Illustrations. Six Books. 4d. and 6d. each. Complete Volume, 3s.6d.

Fairy Tales Old and New. With a Series of Coloured Plates and Numerous Illustrations. 3s. $6 \mathrm{~d}$. Also in five books, $6 d$. each.

French, Cassell's Lessons in. Cheap Edition. In Two Parts. Cluth, Is. 6d. each. Complete in One Vol., 2s. 6d. Key, Is. 6d.

French-English and English-French Dictionary, Cassell's New. Edited by JAMES BÖ̈ELLE, B.A. 7s. 6d.

French-English and English-French Dictionary. I,I50 pages. Cloth or buckram, 3s. 6d. ; half-morocco, 5 s.

Gaudeamus. Songs for Colleges and Schools. Edited by JOHN FARMER. 5s. Words only, paper covers, 6d. : cloth, gd.

German Dictionary, Cassell's. (Ger. man - English, English - German.) Cheap Edition. Cloth, 3s.6d.; halfmorocco, $5 \mathrm{~s}$.

Greek Heroes. New Supplementary Reader. With 4 Coloured Plates, \&c. 6d. ; cloth, Is.

King Solomon's. Mines. Abridged Edition, for Schools. Is. 3 d.

Latin-English and English-Latin Dictionary. $35.6 \mathrm{~d}$, and $5 \mathrm{~s}$.

Latin Primer, The First. By Prof. Postgate. Is.

Latin Primer, The New. By Prof. J. P. Postgate. Crown 8vo, 2s. 6d.

Latin Prose for Lower Forms. By M. A. BAyFIELD, M.A. 2S. $6 \mathrm{~d}$.

Marlborough Books :-Arithmetic Examples, Revised, 35. French Exercises, 3s. 6d. French Grammar, 2s. 6d. German Grammar, 3s. 6d.
Object Lessons from Nature. By Prof. L. C. MislL, F.L.S. Fully Illustrated. New and Enlarged Edition. Two Vols., Is. 6d. each.

Physiology for Schools. By A. T. SCHOFIELD, M.D., \&c. Illustrated. Cloth, Is. 9d. ; Three Parts, paper, 5d. each; or cloth limp, 6d. each.

Reader, The Citizen. By the Rt.Hon. H. O. ARNOLD-Forster, M.A. Revised; Re-set, and Re-illustrated, Is. 6d. Also a Scottish Edition. cloth, Is. $6 \mathrm{~d}$.

Readers, Cassell's Union Jacls Series. With Coloured Plates and numerous Illustrations. 6 Books, from 8d. each.

Readers for Infant Schools, Coloured. Three Books. 4d. each.

Round the Empire. By G. R. PARIin. Fully Illustrated. New and Revised Edition. Is, 6d.

Shakspere's Plays for School Use. Z Books. Illustrated. 6d. each.

Spelling, A Complete Manual of. By J. D. MORELL, LL.D. Cloth, Is. Cheap Edition, 6d.

Spending and Saving: A Primer of Thrift. By ALFRED PINHORN. IS.

Swiss Family Robinson. In words of one syllable. With 4 Coloured Plates. 6d.

Things New and Old; or, Stories from English History. By the Rt. Hon. H. O. ARNOLD.FORSTER, M.A. Illustrated. 7 Books, from gd. to rs. $8 d$.

This World of ours. By the Rt. Hon. H. O. ARNOLD-Forstri, M.A. Illustrated. Cheap Edition. 2s. $6 \mathrm{~d}$.

"Wild Flowers" Sheets, Cassell's. r2 Sheets, each containing ro examples of familiar wild flowers, beautifully reproduced in colours and varnished. Is $6 \mathrm{~d}$. each.

"Wild Birds" Sheets, Casseli's. Selected and Edited by R. KEARTON, F.Z.S. Each sheet is mounted on Board, with Cord Suspender, and contains Eight Examples of Familiar Wild Birds, beautifully reproduced in Colours and Varnished. Six Sheets, Is. 6d. each. Unmounted, 6d. eacb. 


\section{Books for the Little Ones.}

BONSER (A. E.) -

Cassell's Natural History for Young People. With Coloured Frontispiece and numerous lllustrations. $6 \mathrm{~s}$.

ELLIS (EDWARD S.)-

The Lost River. With Four Full. page Illustrations. Is.

River and Forest. With Four Full-page Illustrations. Is.

HAMER (S. H.) Archibald's Amazing Adventure. With 4 Coloured Plates and Numerous Illustrations by HARRY Rountree. Picture Boards, Is. 6d. ; Cloth, 2s.

The Little Folks Adventure Book. With Coloured Plate and Illustrations. 3 S. $6 \mathrm{~d}$.

The Little Folks Picture Album in Colours. With 48 lllustrations in Colours. 5 s.

The Little Folks Animal Book. With Coloured Plate and Illustrations. $35.6 \mathrm{~d}$.

Cheepy the Chicken: Being an Account of some of his most Wonderful Doings. With Four Coloured Plates and numerous Illustrations by HARRY ROUNTREE. IS. 6 d. ; cloth, $2 S$.

Animal Land for Little People. Illustrated. Is, 6d.

Birds, Beasts, and Fishes. With Four Coloured Plates and numerous Illustrations. rs. $6 \mathrm{~d}$.

Master Charlie. Illustrated by C. S. HARRISON. Coloured boards, Is, $6 \mathrm{~d}$.

Micky Magee's Iienagerie; or, Strange Animals and their Doings. With Eight Coloured Plates and other Illustrations by HARRY B. NEILSON. Is. 6d.; cloth, 2S.

Peter Piper's Peepshow. With Illustrations by H. B. NEILSON and LEWIS BAUMER. IS. 6d. ; cloth, 2s.

Quackles, Junior: Being the Extraordinary Adventures of a Duckling. With Four Coloured Plates and other Illustrations by HARRY ROUNTFEE. IS, 6d.; cloth, 2 .
HAMER (S. H.) ContinuedThe Ten Travellers. With Four Coloured Plates and numerous Illustrations by HARRY B. NEILSON. IS. 6d. ; cloth, $2 \mathrm{~S}$.

The Jungle School; or, Dr. Jibber-Jabber Burchall's Academy. With Illustrations by $\mathrm{H}$. B. Neilson. rs. 6d. ; cloth, 2 .

Whys and Other Whys; or, Curious Creatures and Their Tales. By S. H. HAMER and HARRY B. NEILson. Paper boards, 2s. 6 d. ; cloth, 3s. 6 d.

Bo-Peep. A Treasury for the Little Ones. With 4 Full-page Coloured Plates, and numerous other Iliustrations. Yearly Volume. Picture boards, 2s. 6 d. ; cloth, 3s. 6 d.

The Little Folks Sunday Book. With Coloured Plates and Fuil-page Jllustrations. $5 \mathrm{~s}$.

The Little Folizs Buok of Heroes. With Coloured Frontispiece and numerous Illustrations. $3 \mathrm{~s} .6 \mathrm{~d}$.

KNOX (ISA CRAIG) -

The Little Folks History of England. With 30 Illustrations and 4 Coloured Plates. Is. 6d.

"Little Folks " Half-Yearly Volume. Containing 480 pages, with Six Full-page Coloured Plates, and numerous other Illustrations. Picture boards, 3s. 6d. Cloth gilt, gilt edges, 5s, each.

Little Folks Fairy Book, The. With Coloured Frontispiece and numerous Illustrations. $3 \mathrm{~s}$. $6 \mathrm{~d}$.

Merry Hours. With 2 Coloured Plates and Numerous Illustrations. Is.

Our Picture Boolr. With 2 Coloured Plates and Numerous Illustrations. Is.

"Tiny Tots" Annual Volume. Boards, Is. 4d. ; cloth, Is. 6 d.

Tiny Tales. With 2 Coloured Plates and numerous lllustrations. Is.

MONSELL ( I. R.) -

Funny Foreigners. Illustrated $6 d$. net Surprising Strangers. Illustrated $6 \mathrm{~d}$. net.

Notable Nations. Illustrated 6d. net. 

4

4 

SMITHSONIAN INSTITUTION LIBRARIES 